\title{
Results of Geologic Exploration
}

By Core Drilling, 1953 Land-Pebble Phosphate District Florida

GEOLOGICAL SURVEY BULLETIN 1046 - K

This report concerns work done on behalf of the U.S. Atomic Energy Commission and is published with the permission of the Commission 


\section{Results of Geologic Exploration}

By Core Drilling, 1953

Land-Pebble Phosphate District Florida

By JAMES B. CATHCART and LAWRENCE J. McGREEVY

CONTRIBUTIONS TO THE GEOLOGY OF URANIUM

G E O L O I C A L S U R V E Y B U L L E T I N $1046-\mathrm{K}$

This report concerns work done on behalf. of the U.S. Atomic Energy Commission and is published with the permission of the Commission

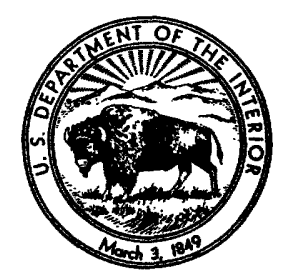




\section{UNITED STATES DEPARTMENT OF THE INTERIOR}

FRED A. SEATON, Secretary

\section{GEOLOGIGAL SURVEY}

Thomas B. Nolan, Director

The U. S. Geological Survey Library has cataloged this publication as follows :

Cathcart, James Bachelder, 1917-

Results of geologic exploration by core drilling, 1953, land-pebble phosphate district, Florida, by James B. Cathcart and Lawrence J. McGreevy. Washington, U. S. Govt. Print. Off., 1959.

iv, 221-298 p. map, col. diagr., profiles, tables. $23 \mathrm{~cm}$. (U. S. Geological Survey. Bulletin 1046-K. Contributions to the geology of uranium )

"Work done on behalf of the U. S. Atomic Energy Commission." Part of illustrative matter in pocket.

Bibliography : p. 267-268.

1. Borings - Florida. 2. Mines and minerals resources - Florida. I. McGreevy, Lawrence J., joint author. II. Title : Land-pebble phosphate district, Florida. (Series: U. S. Geological Survey. Bulletin 1046-K. Series: tions to the geology of U. S. Geological Survey. Contribuuranium)

557.59 


\section{CONTENTS}

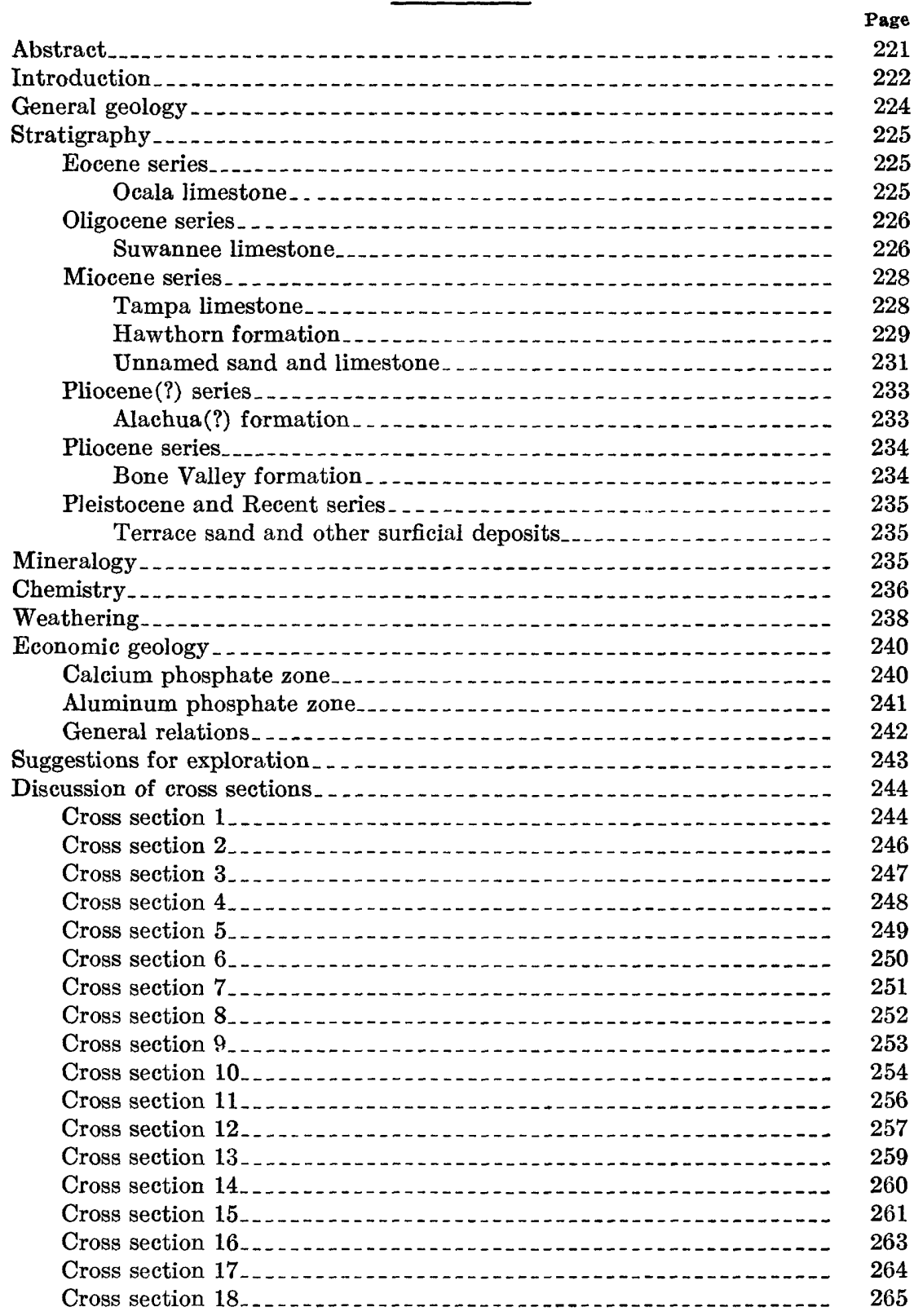


Tonnage calculations Page

Aluminum phosphate zone............ 266

Calcium phosphate zone (matrix)

References cited.............. 267

Basic data...

Analytical and screen data for cross sections 1-18_.............. 271

Tonnage computations for cross sections 1-18_...

Index . . . . . 297

\section{ILLUSTRATIONS}

[All plates in map case]

Plate 16. Cross section 1.

17. Cross section 2.

18. Cross section 3 .

19. Cross section 4 .

20. Cross section 5 .

21. Cross section 6.

22. Cross section 7.

23. Cross section 8.

24. Cross section 9.

25. Cross section 10 .

26. Cross section 11 .

27. Cross section 12.

28. Cross section 13.

29. Cross section 14 .

30. Cross section 15 .

31. Cross section 16.

32. Cross section 17.

33. Cross section 18.

34. Isometric fence diagram, land-pebble phosphate district, Florida.

Frgure 26. Index map of the land-pebble phosphate district, Florida...- 


\title{
CONTRIBUTIONS TO THE GEOLOGY OF URANIUM
}

\section{RESULTS OF GEOLOGIC EXPLORATION BY CORE DRILLING, 1953, LAND-PEBBLE PHOSPHATE DISTRICT, FLORIDA}

\author{
By James B. Cathcart and Lawrence J. McGreevy
}

\begin{abstract}
A program of core drilling to delimit the uranium- and phosphate-bearing strata (the aluminum and calcium phosphate zones) of the land-pebble phosphate district, and to study the stratigraphic relations of the Bone Valley formation, was carried out in the fall of 1953.

A series of cross sections, an isometric fence diagram, and a series of tables summarize the lithologic, stratigraphic, analytical, and economic data derived from the drilling.

The Bone Valley formation of Pliocene age was deposited by a transgressing sea. In most of the district, the Bone Valley overlies limestone or dolomite of the Hawthorn formation (middle Miocene) ; but in the northern part of the district in northern Polk County, where the Hawthorn thins to an erosional featheredge, the Bone Valley overlies the Tampa formation (early Miocene), and farther to the north, in Pasco County, clayey sand of the upper part of the Bone Valley overlies the Suwannee limestone (Oligocene). To the east and south, however, the Bone Valley overlies unnamed sand and limestone that contains fossils of late middle Miocene age. This material in turn overlies the limestone or dolomite of the Hawthorn formation.

In the northernmost line of holes drilled, material correlated with the upper part of the Bone Valley on the basis of lithologic character overlies a sandy clay that contains angular white phosphate particles, material very similar to the hard-rock phosphate. It is thought that this material, here called Alachua (?) formation, may represent the Alachua formation. It appears, therefore, that the Bone Valley is in part equivalent to the Alachua formation, but that a part of the Bone Valley formation may be somewhat younger than the Alachua. Three holes in the northeast part of the area penetrated the Ocala limestone (Eocene). Indications are that this limestone may occupy an upthrown fault block.

After the deposition of the Bone Valley, weathering altered the formation, changing fluorapatite to wavellite and crandallite (pseudo-wavellite), and forming the aluminum phosphate zone.

In the northwestern part of the land-pebble district, the aluminum phosphate zone extends beyond the limits of the calcium phosphate zone. To the east and south, the calcium phosphate zone extends beyond the limits of the aluminum
\end{abstract}


phosphate zone. In the northern part of the area where the phosphate deposition was thinnest the entire Bone Valley formation may have been leached, whereas to the south, where the formation was thicker, only the top part of the formation was leached, and both zones are present. Still farther to the south, in Hardee and Manatee Counties, the Bone Valley formation may not have been exposed to subaerial weathering, and the aluminum phosphate zone was not formed. The present limit of the aluminum phosphate zone is the result of a combination of erosion after the zone was formed, and the possibility that to the east and south, phosphatic sediments were not exposed to weathering in the Pliocene. The aluminum phosphate zone and the calcium phosphate zone both cut across stratigraphic units. This is clearly shown in some of the cross sections where, for example, aluminum phosphate minerals have formed in the Bone Valley, the Hawthorn, and the Tampa formations. The calcium phosphate zone may be entirely within the Bone Valley formation, entirely within the Hawthorn formation, or most commonly, it includes the bottom part of the Bone Valley, and the weathered top of the Hawthorn formation. The phosphate deposits of the land-pebble district are thus complex-partly residual, partly marine reworked, and partly phosphatized clay.

\section{INTRODUCTION}

The land-pebble phosphate district is located in west-central peninsular Florida between $27^{\circ} 00^{\prime}$ and $28^{\circ} 15^{\prime}$ north latitude and $81^{\circ} 45^{\prime}$ and $82^{\circ} 15^{\prime}$ west longitude. The district is divided on the basis of phosphate content and tonnage into a northern, high-grade part, which is in Polk and Hillsborough Counties, and a southern, lower grade part, which is in Hardee and Manatee Counties (fig. 26).

A program of core drilling to delimit the uranium- and phosphatebearing strata of the Bone Valley formation, and to study the stratigraphic relations of the Bone Valley formation was conducted by the U. S. Geological Survey on behalf of the Division of Raw Materials of the U. S. Atomic Energy Commission. The drilling was done by a private firm under contract let by the Atomic Energy Commission. A spokelike pattern of lines of drill-hole sites was laid out; the first site in each line was selected within the limits of the land-pebble phosphate district. Drilling permits from the landowners were obtained under the direction of Emerson C. Willey of the Geological Survey. A sampler followed the drilling in the field, checked core recovery, and collected chip samples from the core at 1-foot intervals. A total of 115 holes aggregating 7,112 feet was drilled from May 26 to October 21,1953 , with a truck-mounted rotary drill. Heavy drilling mud was used to prevent caving and contamination during coring. Average core recovery was 74 percent; losses were noted and are shown on the cross sections. Holes with low recovery were redrilled to recover enough sample for analytical purposes. All holes were cased with 11/2-inch inside diameter (ID) cast-iron pipe, and gammaray logs were made. Casing was necessary to prevent caving prior to gamma-ray logging. 


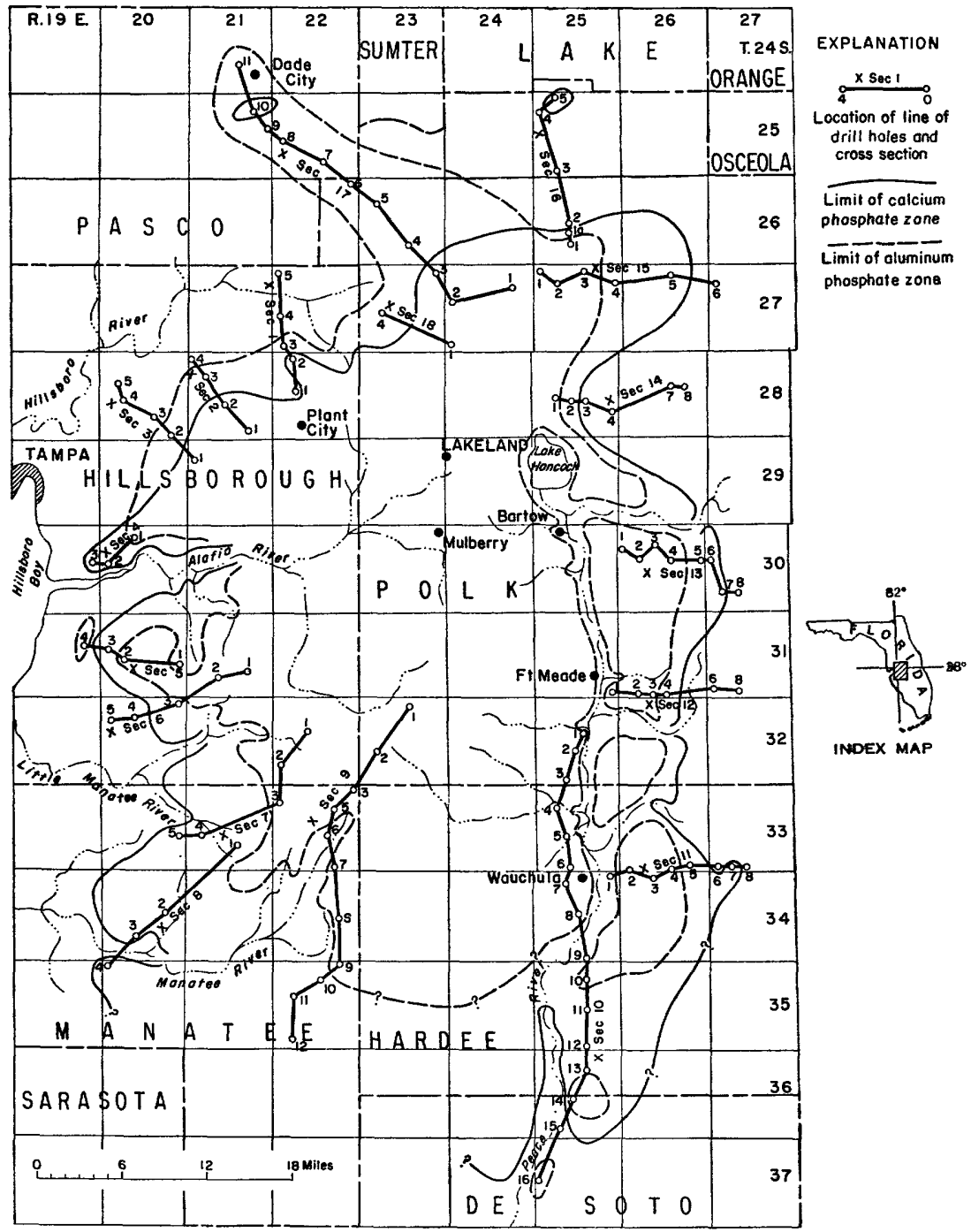

Fladre 26.-Index map of the land-pebble phosphate district, Florida, showing limits of calcium phosphate and aluminum phosphate zones.

Samples corresponding to the high-peak areas on the gamma-ray logs were split from most cores for analysis. These samples represent, at least in part, the aluminum phosphate zone. Where visual inspection showed abundant phosphate grains, a sample was also taken that represented the calcium phosphate zone or "matrix." The sample was weighed, then washed over a 14-mesh screen, and the oversize retained, dried, and weighed. The undersize was screened on 35- and 150 -mesh screens. The material retained on the 35-mesh screen was 
dried and weighed. If phosphate minerals were present in the $-35+150$-mesh material, it was treated in a laboratory flotation cell to separate the quartz sand and phosphate minerals. The material passing the 150-mesh screen (the slime fraction) was dried, weighed, and retained. Weight percents of sample fractions were computed from the dry weights. Equivalent uranium and, where necessary, chemical uranium were determined for all sample splits. The samples highest in uranium content were analyzed for $\mathrm{P}_{2} \mathrm{O}_{5}, \mathrm{CaO}, \mathrm{F}$, and $\mathrm{Al}_{2} \mathrm{O}_{3}$.

The drill holes were logged by the following geologists: D. C. Alverson, W. J. Carr, J. B. Cathcart, K. B. Ketner, L. J. McGreevy, and R. G. Petersen of the U. S. Geological Survey. Samples of the fossiliferous material were examined by F. Stearns MacNeil of the U. S. Geological Survey, and all fossil determinations and age assignments from fossils were made by him.

Studies of the limestone cores from cross sections 1-4 were made by W. J. Carr and D. C. Alverson (1953), and the writers have used their age assignments for nonfossiliferous limestone in those sections. A. M. Coleman and Charlotte Axsell assisted the writers in the preparation of the tables and illustrations. All analytical work was done in the laboratories of the U. S. Geological Survey. Radioactivity analyses were made by J. Goode and B. McCall under direction of F. Flanagan. Chemical analyses were done by J. Smith, W. Tucker, J. Budinsky, L. Jenkins, E. Campbell, I. Barlow, R. Smith, S. Bethea, R. Moore, A. Sweeney, T. Murphy, J. Waring, and G. Daniels, under direction of I. May.

All the factual data obtained during the drilling are given in tables at the end of the report. Mechanical and chemical analyses are given for all samples, and tonnage and grade computations are given for the aluminum phosphate and calcium phosphate zones.

A series of cross sections, one for each line of drill holes, summarize the lithologic, stratigraphic, and economic data. Lithologic correlations, shown in dashed lines, were made from geologists' logs of the core, plus the writers' examination of the core chips with the binocular microscope. The writers' stratigraphic correlations are shown in solid lines, and are based on lithology, except for the few fossiliferous beds. The fossil lists and age identifications are given in the text.

The aluminum phosphate and the calcium phosphate zones are delimited by stippled patterns. The delineation of these zones was made with the use of the chemical analyses of the samples, and for the aluminum phosphate zone, from the high peaks on the gamma-ray logs.

\section{GENERAL GEOLOGY}

The land-pebble phosphate district is a part of the Gulf Coastal Plain, and is underlain by thin, nearly flat-lying formations that dip 
very gently to the south and southeast. King (1951) has pointed out that the geology of peninsular Florida differs from that of the remainder of the coastal plain in that Florida was a positive, relatively stable area during a large part of middle and late Mesozoic and Cenozoic time, and because of its distance from the main part of the North American continent, it received relatively small amounts of land-derived sediment.

Phosphate deposits in the land-pebble district are part of the Bone Valley formation of probable Pliocene age and (or) phosphatebearing sandy clay of the Hawthorn formation. The Bone Valley formation was deposited on the eroded surface of the underlying phosphatic Hawthorn formation of middle Miocene age, and in the northern part of the district, where the Hawthorn formation thins to an erosional featheredge, on the Tampa formation of early Miocene age. On the fringes of the district (to the north, west, and east), drilling penetrated rocks of the Suwannee limestone of Oligocene age and the Ocala limestone of Eocene age, and on the northern edges of the district, clayey sand, tentatively assigned to the Bone Valley formation on the basis of lithologic character, rests on the Suwannee limestone.

The Bone Valley formation was deposited by a transgressing sea that reworked and partly sorted the residual mantle formed on the Hawthorn at the close of the Miocene. After its deposition, the upper part of the Bone Valley was deeply weathered. Much of the phosphate in this upper zone has been removed, and some of the phosphate combined with alumina from clay minerals to form aluminum phosphate minerals. The phosphate deposits of the Bone Valley are thus complex - partly residual, partly marine reworked, and partly phosphatized clay.

The district is covered by a blanket of loose quartz sand of probable Pleistocene age. Wind-blown sand, swamp deposits, and bars and flood plains of streams are probably Recent.

\section{STRATIGRAPHY}

Details of the stratigraphy and local stratigraphic relations, are shown on plates 16-33. Stratigraphic relations and the geographic distribution of the formations based on core drilling are shown on plate 34 .

\section{EOCENE SERIES}

OCALA LIMESTONE

The Ocala limestone was named by Dall and Harris (1892, p. 103), for the city of Ocala in Marion County. Cooke (1915, p. 117) believed the Ocala was of late Eocene age. Vernon (1951, pp. 111-113) 
divided the Ocala into his Ocala limestone (restricted) at the top and the Moodys Branch formation as used by him at the base. He divided the Moodys Branch formation into a lower, his Inglis, member, and an upper, his Williston, member. Because only a few, short cores of the Ocala were obtained in the present study, it was not possible to subdivide the Ocala.

The Ocala is a white, cream to yellow very pure limestone, which in places contains over 99 percent calcium carbonate. It ranges in thickness from about 50 to almost 400 feet.

Ocala fossils were collected at the following locations:

Cross section 15, hole 5 (SW1/4 SW1/4 sec. 3, T. 27 S., R. 26 E.) :

Amusium ocalanum

Cross section 16, hole 1a (SW1/4SW1/4 sec. 21, T. 26 S., R. 25 E.) :

Chlamys sp. cf. C. spillmani

Lepidocyclina ocalana

Tubulostum sp.

Cross section 16, hole 2 (NW1/4NW1/4 sec. 21 , T. 26 S., R. 25 E.) :

Lepidocyclina sp. cf. L. pseudomarginata

The elevation of the Ocala limestone in these holes is about the same as the elevation of the Hawthorn formation in adjacent holes. (See pls. 30 and 31.) Calcareous clay, assigned to the Hawthorn, overlies the Ocala limestone at these drill holes. This indicates that a part of the Hawthorn formation, the Tampa limestone and the Suwannee limestone, may have been cut out. Thus, the Ocala limestone here may occupy an upthrown fault block (see pl. 34). If this is a fault block, the age of the faulting is probably pre-Bone Valley, because sediments assigned to the Bone Valley are apparently not affected by the faulting.

\section{OLIGOCENE SERIES}

\section{SUWANNEE LMMESTONE}

The name Suwannee limestone was proposed by Cooke and Mansfield $(1936$, p. 71$)$ for limestone exposed along the banks of the Suwannee River. Cooke (1945, p. 88) says the Suwannee is the equivalent of the Chickasawhay limestone of late Oligocene age. MacNeil (1947) indicates that the Suwannee limestone is the equivalent of the Byram and the Chickasawhay formations combined, and thus includes rocks of middle and late Oligocene age.

The Suwannee limestone is a yellow or cream limestone. It is commonly soft and granular. Small solution holes, filled with green clay, probably residual from the limestone, are abundant. In places, the lime has been leached from the surface of the limestone, leaving a mass of flint. Chemical analyses (Mossom, 1925) show that the Suwannee contains between 91 and 98 percent calcium carbonate.

The Suwannee limestone lies unconformably on the Ocala, and is unconformably overlain by the Tampa limestone, of early Miocene 
age or by younger rocks. The thickness of the Suwannee limestone in the land-pebble district is about 130 feet (MacNeil, oral communication, 1956).

Suwannee fossils were collected at the following localities:

Cross section 1, hole 4 (SW $1 / 4$ NE1/4 sec. 19, T. 27 S., R. 22 E.) :

Kuphus incrassatus

Phacoides (Miltha) sp. aff. P. chipolanus

Turritella? n. sp.

sp. aff. $T$. bowenae

Cross section 2, hole 4 (NE1/4SW1/4sec. 6, T. 28 S., R. 21 E.) :

Chlamys sp. cf. $C$. brooksvillensis

Kuphus incrassatus

Peneroplis sp.

Sorites sp.

Cross section 17, hole 5 ( SW $1 / 4$ SW1/4 sec. 8, T. 26 S., R. 23 E.) :

Amauropsis? sp.

Anatina sp.

Chione sp.

Chlamys sp. cf. $C$. brooksvillensis

Corbula sp.

Divaricella sp.

Glycymeris suwannensis

Myrtaea sp. cf. $M$. taylorensis

Orthaulax hernandensis

Pitar sp.

sp. cf. P. heilprini

Turritella halensis

Venus sp.

Cross section 17, hole 6 (NW $1 / 4 N^{1 / 4}$ sec. 1, T. 26 S., R. 22 E.) :

Barnea sp.

Coskinolina floridana

Tritiaria? n. sp.

Venus sp.

Cross section 17, hole 9 (NW1/4 SE $1 / 4$ sec. 13, T. 25 S., R. 21 E.) :

Asterigina subacula floridensis

Peneroplis sp.

Cross section 17, hole 10 (SW1/4/4E1/4 sec. 11, T. 25 S., R. 21 E.) :

Asterigina subacula floridensis

Peneroplis sp.

Sorites sp.

Cross section 17, hole 11 (NW1/4SE1/4 sec. 22, T. 24 S., R. 21 E.) :

Sorites sp.

In addition to the fossiliferous limestone, material at the bottom of hole 5 of cross section 1 , hole 3 of cross section 2 , and holes 3,7 , and 8 of cross section 17, was tentatively assigned to the Suwannee. All of the drill holes that penetrated Suwannee limestone are at the north end of the mapped area (pl. 26). In this part of the area, the Tampa and Hawthorn formations, which normally overlie the Suwannee, are thinning. None of the holes in the south, east, or west 
penetrated the Suwannee limestone, which indicates a general thickening of the younger formations southward.

\section{MIOCENE SERIES}

TAMPA LIMESTONE

The name Tampa formation was first used by Johnson (1888, p. 235) ; Cooke and Mossom (1929, p. 78-93) changed the name to Tampa limestone. Both Cooke (1945) and MacNeil (1947) put the Tampa limestone in the early Miocene.

The limestone of the Tampa is much more variable in composition than either the Suwannee or the Ocala. It is a white to cream sandy and clayey limestone, and contains abundant chert fragments and very few phosphate nodules. The limestone is interbedded with keds of clay and sandy clay, and is often covered with a residual mantle of green calcareous clay that contains chert and limestone fragments and a few phosphate nodules.

The Tampa limestone lies unconformably on the Suwannee limestone, but the relations between the Tampa and the overlying formations are uncertain. Cooke $(1945$, p. 115) indicates that in the northern part of Florida, near the Georgia State line, the contact between Tampa limestone and Hawthorn formation is gradational and conformable. Recent work by Carr and Alverson (1953, p. 182) in the land-pebble district indicates that the contact between the Tampa and the Hawthorn is marked by an erosional interval. According to Mansfield $(1937$, p. 14) the Tampa limestone is about 65 feet thick near Tampa.

Tampa fossils were collected at the following localities:

Cross section 1, hole 3 (NE1/4 SE1/4 sec. 31, T. 27 S., R. 22 E.) : Helisoma sp.

Cross section 2 , hole 3 (SE1/4 SE $1 / 4$ sec. 8, T. 28 S., R. 21 E.) (molds and casts in siliceous bed at top of calcareous clay) :

Helisoma sp.

Cross section 3, hole 2 (SE1/4 SE1/4 sec. 35, T. 28 S., R. 20 E.) (fossils in limestone fragments in green clay) :

Camerina sp.

Sorites sp.

Trigonacardia sp.

Cross section 4, hole 1 (SW1/4 SW1/4 sec. 4, T. 30 S., R. 20 E.) :

Anomalocardia penita

Arca irregularis

Cardium sp. cf. C. anclotensis

Murex sp. cf. M. trophonoformis

Cross section 4, hole 3 (NW1/4 SE1/4 sec. 13, T. 30 S., R. 19 E.) :

Sorites sp. 
Cross section 14, hole 7 (NW1/4 SE1/4 sec. 15 , T. 28 S., R. 26 E.) :

Amauropsis sp.

Arcopsis sp.

Chlamys crocus

Phacoides sp.

Turritella tampae

Hillsboroensis

Cross section 14, hole 8 (NW1/4 SE1/4 sec. 14, T. 28 S., R. 26 E.) :

Camerina sp.

Peneroplis sp.

Sorites sp.

Venus sp.

Cross section 17 , hole 4 (NE1/4 SW1/4 sec. 27 , T. 26 S., R. 23 E.) :

Anadara latidentata

Architectonica? n. sp.

Callocardia sp.

Cardium delphicum

Chlamys sp.

Corbula sp.

Knefastia sp. cf. $K$. brooksvillensis

Olivella sp. cf. O. posti

Pitar sp.

Terebra sp.

Turritella atacta

Venus sp.

Cross section 17, hole 9 (NW1/4 SE1/4 sec. 13, T. 25 S., R. 21 E.) :

Glycymeris sp.

In addition to the fossiliferous localities, limestone or clastic rock called Tampa on the basis of lithologic character was cored at holes 1 , 2 , and 4 of cross section 1 , hole 4 of cross section 2 , holes 1 and 3-5 of cross section 3 , hole 4 of cross section 14, and holes $3,5-8$, and 10 of cross section 17. All of the drill holes that intersected limestone or clastic rock of the Tampa are in the northern half of the area mapped, but, in the northernmost holes of cross sections 1 and 17, the Tampa was missing, and the formation thins northward. Because the formation extends farther to the north than does the overlying Hawthorn, the thinning may be in part, at least, erosional.

\section{HAWTHORN FORMATION}

The Hawthorn formation was named for the town of Hawthorn, Alachua County, by Dall and Harris (1892, p. 107). The Hawthorn was placed in the middle Miocene by Cooke (1945) and MacNeil (1947). In the land-pebble district the Hawthorn formation consists of interbedded layers of limestone or dolomite, sand, sandy clay, and greenish-blue or gray clay, all of which contain abundant phosphate nodules. Where exposed in the mining pits of the land-pebble district, the Hawthorn formation is a soft buff to yellow sandy, clayey phosphate-bearing dolomite. In studying cuttings from a deep well 
Berman (1953) found an abrupt change at 80 feet from dolomite to limestone. It is believed that the upper dolomitic zone may be a replacement of the limestone.

A thin, discontinuous deposit of soft, water-saturated plastic sandy calcareous clay (called bedclay by the phosphate companies) overlies the dolomite of the Hawthorn formation in most of the pits in the district. This clay is gradational with the material below and probably was derived from the hard dolomite beneath by leaching.

No limestone of the Hawthorn formation was found in the drill holes in the northern fringe of the district (See pls. 16, 17, 32, and 33.) The formation is very thin in this area and pinches out northward. In the southern part of the area, the drill holes penetrated sandy clay, clay, and sand of the Hawthorn formation, but many bottomed in limestone or dolomite of the Hawthorn (See pls. 22, 23, and 25.) The Hawthorn formation is unconformably overlain by the Bone Valley formation of Pliocene age, or by sand of the Pleistocene. The Hawthorn ranges in thickness from a featheredge north of the district to a maximum of several hundred feet south of the district.

Hawthorn fossils were collected at the following localities:

Cross section 4 , hole 2 ( $\mathrm{SW}^{1} / 4 \mathrm{SW}^{1} / 4$ sec. 18 , T. 30 S., R. 20 E.) : Ostrea sp.

Cross section 10, hole 8 (SW1/4 SW1/4 sec. 15, T. 34 S., R. 25 E.) :

Anadara sp.

Chione sp.

Cross section 11, hole 1 (NW1/4NW1/4 sec. 1, T. 34 S., R. 25 E.) (late Hawthorn age) :

Anadara sp.

Cancellaria sp.

Cardium sp.

Dosinia sp.

Glycymeris sp.

Phacoides sp.

Plicatula sp.

Semicassus?

Venericardia sp.

Venus sp.

Cross section 11, hole 5 (NE1/4 SE1/4 sec. 35, T. 33 S., R. 26 E.) :

Glycymeris sp.

Phacoides sp.

Cross section 11, hole 6 (NE1/4 SE1/4 sec. 31, T. 33 S., R. 27 E.) :

Chione sp.

Chlamys sp.

Venericardia sp.

Venus sp.

Cross section 12, hole 1 (sec. 36, T. 31 S., R. 25 E.) (Hawthorn?) :

Anadara sp.

Cross section 12, hole $6\left(\mathrm{NW}^{1 / 4} \mathrm{NE}^{1 / 4}\right.$ sec. 31 , T. 31 S., R. 27 E.) (fossils are in a limestone gravel) :

Chlamys sp. 
Cross section 12, hole 8 (NE1/4 SW1/4 sec. 33, T. 31 S., R. 27 E.) (Hawthorn?) :

Chlamys sp.

Pecten sp.

Turritella sp.

Cross section 13, hole 1 (SW1/4 SW $1 / 4$ sec. 7, T. 30 S., R. 26 E.) (Hawthorn?) :

Chlamys sp.

Phacoides sp.

Venericardia sp.

Cross section 13, hole 2 (NW1/4 SE1/4 sec. 17, T. 30 S., R. 26 E.) :

Anadara sp.

Chione chipolana

Cross section 13, hole 5 (NW1/4 SE1/4 sec. 13, T. 30 S., R. 26 E.) :

Cardium (Trachycardium) sp.

Chlamys sp. (Probably sayanus)

Tellina sp.

Limestone and clastic rock, correlated with the Hawthorn formation on the basis of lithologic character, were cut by all drill holes except holes 4 and 5 of cross section 1, and holes $4-11$ of cross section 17 . (See pls. 16 and 32.) The approximate northern limit of the Hawthorn formation is shown on plate 34. The northward thinning and pinch out of the Hawthorn is shown on plates 16 and 32. In addition, plate 18 indicates a westward thinning of the Hawthorn. The northern thinning of the Hawthorn is believed to be erosional; outliers of the formation are shown on the geologic map of Florida (Cooke, 1945 ), to the north of the area mapped. The thickening of the formation southward is shown from logs of deep wells.

\section{UNNAMED SAND AND LIMESTONE}

Fossils, identified as being near the middle Miocene-late Miocene boundary in age, were found in three drill holes. These three collections are identified as late middle Miocene, middle(?) Miocene, and late(?) Miocene in age respectively. The beds from which the fossils came and others correlated with them on the basis of lithologic similarity are grouped into a single unnamed sand and limestone unit of middle Miocene to late( ?) Miocene age.

On the eastern fringe of the district in eastern Polk County the easternmost drill holes in cross sections 12 and 15 (pls. 27 and 30) penetrated a bed of olive-green fine to very fine grained micaceous clayey sand that contains abundant shell fragments and a minor amount of black phosphate grains. Lithologically similar material was identified in cross sections 11,13 , and 14 (see pls. 26, 28, and 29), and is tentatively correlated with this fossiliferous bed. The fossiliferous material in hole 8 ( $\mathrm{pl} .27$ ), identified as late middle Miocene in age, overlies fossiliferous limestone of the Hawthorn formation. In hole 6 (pl. 30), the fossiliferous material, identified as middle(?) Miocene, overlies limestone that is assigned to the Hawthorn on the basis of lithologic character. 
Southward at the north end of De Soto County (hole 14, pl. 25) fossils identified as late(?) Miocene were found in a white to cream sandy and clayey limestone that contains a few black phosphate nodules. This fossiliferous bed overlies a nonfossiliferous limestone that is put in the Hawthurn because of its lithologic character. According to Bergendahl (1956) most of the upper Miocene is sand but contains variable amounts of clay. This sand, from Bergendahl's description of it, is similar to the sand in the eastern part of the area of this report, and was penetrated in holes 12, 13, 15, and 16 at the south end of cross section 10. That part of Bergendahl's sand of the upper Miocene penetrated in cross section 10 is placed in the unnamed sand and limestone unit in this report.

The clayey sand beds of cross sections 11-15 lie to the east of the crest of a subsurface ridge that is parallel to and east of the Peace River. The land-pebble phosphate district as an economic unit does not extend to the east of this ridge (see fig. 26), although noneconomic phosphate beds overlie the unnamed sand and limestone unit east of the ridge.

The total thickness of the unnamed unit is uncertain. In hole 8 (pl. 27) a tan sand, containing abundant coarse phosphate, overlies the olive-green clayey sand that contains late middle Miocene fossils. This tan material is tentatively put into the Bone Valley and if this correlation is correct, the unnamed sand and limestone unit is only 10 feet thick in this drill hole, from a depth of 59.8 feet (the base of the phosphorite bed) to 70.1 feet (the top of the fossiliferous Hawthorn). In hole 6 (pl. 30) the fossiliferous beds of the unnamed unit are overlain by a tan sand that contains coarse phosphate nodules, which is also tentatively put into the Bone Valley, and are underlain by nonfossiliferous limestone, called Hawthorn on the basis of its lithologic character. The unnamed beds extend from a depth of 74.4 to 86.0 feet, a thickness of only 11.6 feet. This may represent the approximate shoreline of the late middle Miocene sea, as the unit thickens to the east and south as shown on the cross sections, plates 25-30. In hole 16 (pl. 25) the olive-green sand tentatively correlated with the unnamed unit extends from a depth of 28.0 to 84.0 feet, a thickness of 56 feet.

Fossils identified are as follows:

Cross section 10, hole 14 (N1/2 SE $1 / 2$ sec. 21, T. 36 S., R. 25 E.) :

Cardita sp.

Cardium sp.

Chlamys sp.

Ostrea sp. aff. O. puelchana

Spisula?

Venus? 
The oyster ( $O$. sp aff. $O$. puelchana) is unlike anything in the Hawthorn, and this assemblage is identified as upper (?) Miocene.

Cross section 12, hole 8 ( $\mathrm{NE}^{1 / 4} / 4 \mathrm{NW}_{1 / 4}$ sec. 33, T. 31 S., 27 E.) :

Anadara sp.

Anomia sp.

Chlamys sp.

Dosinia sp.

Mulinia orthria

Phacoides sp.

Mulinia orthria has been known only in the Shoal River formation of middle Miocene age. (This is a late middle Miocene assemblage).

Cross section 15, hole 6 (NE1/4NW1/4 sec. 7. T. 27 S., R. 27 E.) :

Anadara sp. cf. A. idonea harveyensis

Cancellaria sp. cf. C. tabulata

Chlamys (Plagioctenium) eboreus subsp. watsonensis

Crepidula sp.

Olivella sayana

Pecten (Pecten) sp.

Spisula (Hemimactra) dehumbis

Turritella sp. cf. T. alumensis

Venus sp.

\section{PLIOCENE (P) SERIES}

ALACHUA (?) FORMATTON

The name Alachua was applied by Dall and Harris (1892, p. 127) to the bone-bearing beds found in sinks in Alachua County. Cooke (1945, p. 199) puts the Alachua in the middle Pliocene. Vernon (1951, p. 183) suggests that the Alachua formation ranges in age from lower Miocene to Pleistocene, and includes the terrestrial equivalent of the entire marine Miocene of Florida. Fossils found in the Alachua include bones of Miocene, Pliocene and Pleistocene animals. Simpson $(1929$, p. $259 ; 1930$, p. 176) regarded the Pliocene animals as the indigenous fauna.

The formation is a blue, gray, or green sandy clay, which weathers to a yellow or red. The sand fraction is medium to coarse grained; the formation also contains white angular fragments of phosphate.

Sediments assigned to the Alachua (?) formation were cored only in holes 8-11 of cross section 17 (pl. 32). The sediments are nonfossiliferous coarse sandy clays containing angular white phosphate fragments. They overlie rocks assigned to the Tampa in holes 810, and Suwanee limestone in hole 11. Coarse quartz grains are not found in the Ocala, Suwannee, or Tampa limestones, but are characteristic of the Hawthorn. It is likely, therefore, that the sediments assigned to the Alachua(?) were derived largely from the Hawthorn, if they are not a residuum of the Hawthorn. The angu- 
lar phosphate fragments are probably phosphatized Ocala or Suwannee limestone. The fragments are present throughout the Alachua (?) and may indicate some reworking. The Alachua(?) is overlain at hole 10 of cross section 17 by a sandy clay, containing phosphate nodules, that is similar lithologically to the lower part of the Bone Valley and so assigned. In holes 8, 9, and 11 of cross section 17, the Alachua (?) is overlain by clayey sand lithologically similar to the upper Bone Valley and assigned accordingly. It seems likely, therefore, that these sediments assigned to the Alachua(?) are at least in part equivalent to the Bone Valley, but may also be somewhat older.

\section{PLIOCENE SERIES}

\section{BONE VALLEY FORMATION}

The Bone Valley gravel was named by Matson and Clapp (1909, p. 138-141), from a railroad stop west of Bartow, Fla. They divided the Bone Valley gravel into a lower unit rich in phosphate nodules and an upper, noneconomic unit that contains only traces of phosphate. Cooke (1945, p. 203) suggested a change in name to Bone Valley formation, as gravel makes up only a small part of the material.

The Bone Valley formation is generally regarded as Pliocene in age on the basis of land vertebrates (Simpson, 1929), although it may be latest Miocene. Brodkorb (1955, p. 38-39) says: "The avifauna, therefore, must be of late Miocene to middle Pliocene age, and the agreement is closest to other avifaunas recorded from the early or middle parts of the Pliocene." Bergendahl (1956) shows an interfingering of "undifferentiated phosphate", in part equivalent to the Bone Valley formation, and a sand containing marine invertebrates that may be very late Miocene in age. At present, this discrepancy in age assignment has not been resolved; the landvertebrate chronology may be a portion of an epoch ahead of the marine-sediments chronology.

The Bone Valley formation consists of a lower unit that is composed of phosphate nodules, sand, and clay, and an upper unit that is composed predominantly of clayey sand but includes minor amounts of phosphate nodules.

The lower unit, which ranges in thickness from a featheredge to more than 30 feet at hole 1 (pl. 23), is composed of interbedded, lenslike beds of sand, clay, and clayey sand. All of the beds contain phosphate particles, and individual beds may vary from almost barren clay or sand to those which are almost entirely phosphate nodules. The upper part of the Bone Valley formation ranges from a slightly clayey sand to a sandy clay, and generally contains a few phosphate 
nodules. The contact between the lower and upper parts of the Bone Valley formation is gradational over a vertical distance of a few inches. The upper part ranges in thickness from a featheredge to about 68 feet at hole 6 (pl. 27). Toward the fringes of the district (cross section 1, pl. 16) the phosphate beds of the lower Bone Valley are not present, and the Pliocene is represented by clayey sands. These beds are lithologically similar to the upper part of the formation and are correlated accordingly.

The lower, phosphorite unit of the Bone Valley formation is present almost throughout the area. The limits of the calcium phosphate zone, shown on figure 26, also represent, at least roughly, the limits of the lower unit of the Bone Valley formation. The lower unit is not present, except as small patches north of Polk and Hillsborough Counties. The limits of the formation to the south are not known; the southernmost drill holes contained material assigned to the Bone Valley on the basis of lithologic similarity.

The upper, clayey sand unit of the Bone Valley formation is present throughout the area mapped. The distinctive lithology, a mediumto-fine-grained quartz sand, lightly bound with white clay, was noted in every drill hole.

\section{PLEISTOCENE AND RECENT SERIES}

\section{TERRACE SAND AND OTHER SURFICIAL DEPOSTTS}

The loose sand overlying the Bone Valley is probably Pleistocene in age. No fossils were found in any of the drill cores, but a few horse teeth of Pleistocene age have been found in the loose surficial sand in the land-pebble district. The sand is nearly pure quartz, with only traces of clay, heavy minerals, and as much as 0.5 percent $\mathrm{P}_{2} \mathrm{O}_{5}$. Generally, the sand is white, but locally is stained gray by organic material or light brown or tan by iron. Wind-blown sand, swamp deposits, and bars and flood-plain deposits of streams are considered Recent in age.

\section{MINERALOGY}

The mineralogy of the land-pebble phosphate district has been described by Altschuler and others (written communication, 1955). For the purposes of this report, the mineralogy will be described only briefly.

Berman (1953) points out that the deeper, unaltered limestone of the Hawthorn in a deep drill hole contains calcite, quartz, a minor amount of apatite, and the clay minerals, either kaolinite or montmorillonite. Closer to the surface the Hawthorn formation consists of dolomite, attapulgite, quartz, and apatite; the "matrix" of the Bone Valley formation is quartz, montmorillonite, and apatite; and the overburden 
is quartz and a minor amount of montmorillonite. This section is typical of those areas where aluminum phosphate minerals were not formed.

X-ray spectrometer analyses of a series of vertical channel samples, each sample representing a very limited vertical interval, were made by L. V. Blade of the Geological Survey in 1952. All of the sections were taken at mines in the district, from the surface to the base of the pit. The following are generalizations from several sections that are believed typical of areas that were leached and where aluminum phosphate minerals were formed.

The loose surface sand contains only quartz, except near the contact with the clayey sand of the upper part of the Bone Valley, where minor kaolinite was detected. The clayey sand of the upper Bone Valley, whether obviously leached or not, contains kaolinite, wavellite, crandallite, and possibly a minor amount of montmorillonite. Quartz is ubiquitous. The same minerals are present at the top of the lower part of the Bone Valley, but at the upper contact, or slightly above it, montmorillonite is the most abundant clay mineral, apatite is abundant, and commonly crandallite is more abundant than wavellite. In the lower Bone Valley ("matrix") apatite and montmorillonite are the most abundant minerals; kaolinite and aluminum phosphate minerals are minor constituents. The residual Hawthorn (bedclay) contains calcite and dolomite in addition to apatite and montmorillonite.

\section{CHEMISTRY}

Analytical and screen data from the drilling are given below. Only samples that were clearly in one of the stratigraphic intervals shown were used. Many of the samples taken included more than a single stratigraphic interval. For example, in many of the drill holes, a single sample of the calcium phosphate zone was taken; the sample may include phosphate of both Hawthorn and Bone Valley.

The weight distribution shows that samples of the limestone of the Hawthorn contain the highest percentages of pebble, and the analyses show that the pebble fraction is low in phosphate, and from the ratio of calcium to phosphate, contain excess calcium. Probably the pebble sample contains abundant particles of slightly phosphatized limestone, as well as the coarser particles of calcium phosphate. The limestone also contains the highest percentage of slime, and the lowest percentage of quartz sand (the tailing fraction) of any of the samples. Clastic rock of the Hawthorn, however, has much less pebble, slightly less slime, much more sand, and about the same amount of concentrate as the limestone.

The phosphate of the unnamed sand and limestone unit differs from the Hawthorn principally in the amount of the slime fraction, which is 
only half of that in the Hawthorn. The pebble fraction is higher, the concentrate about the same, and the sand fraction is increased slightly.

Comparison of screen-size distribution and chemical analyses, and averages of samples from different stratigraphic intervals

[The sample washing and flotation was done by a private firm under contract let by the Geological Survey. All chemical analyses were done in the laboratories of the U. S. Geological Survey]

\begin{tabular}{|c|c|c|c|c|c|c|}
\hline \multirow{4}{*}{ Mesh size } & \multicolumn{6}{|c|}{ Weight percent retained on screen } \\
\hline & \multirow{3}{*}{$\begin{array}{l}\text { Limestone } \\
\text { of the } \\
\text { Hawthorn }\end{array}$} & \multicolumn{4}{|c|}{ Calcium phosphate zone } & \multirow{3}{*}{$\begin{array}{l}\text { Aluminum } \\
\text { phosphate } \\
\text { zone, Bone } \\
\text { Valley }\end{array}$} \\
\hline & & \multirow{2}{*}{$\begin{array}{l}\text { Clastic } \\
\text { rocks of the } \\
\text { Haw thorn }\end{array}$} & \multirow{2}{*}{$\begin{array}{c}\text { Unnamed } \\
\text { unit }\end{array}$} & \multicolumn{2}{|c|}{ Bone Valley (lower) } & \\
\hline & & & & $\underset{\text { phosphate }}{\text { Dark }}$ & $\begin{array}{c}\text { Light } \\
\text { phosphate }\end{array}$ & \\
\hline $\begin{array}{l}+14 \text { (pebble) } \\
-14+35 \text { (feed) } \\
-35+150 \text { (feed) }\end{array}$ & $\begin{array}{l}19.3 \\
10.7\end{array}$ & $\begin{array}{r}5.1 \\
13.0\end{array}$ & $\begin{array}{r}8.3 \\
18.0\end{array}$ & $\begin{array}{l}11.2 \\
14.7\end{array}$ & $\begin{array}{r}8.3 \\
14.3\end{array}$ & $\begin{array}{r}1.6 \\
17.0 \\
66.5\end{array}$ \\
\hline $\begin{array}{l}\text { (Concentrate) } \\
\text { (Tailings) }\end{array}$ & $\begin{array}{l}10.1 \\
25.5 \\
34.4\end{array}$ & $\begin{array}{l}10.5 \\
45.1 \\
26.2\end{array}$ & $\begin{array}{l}10.6 \\
49.6 \\
13.5\end{array}$ & $\begin{array}{r}6.2 \\
54.5 \\
13.4\end{array}$ & $\begin{array}{r}6.8 \\
44.0 \\
26.4\end{array}$ & 14.9 \\
\hline \multicolumn{7}{|c|}{ Percent $\mathrm{P}_{2} \mathrm{O}_{5}$} \\
\hline $\begin{array}{l}\text { Pebble } \\
\text { Concentrate } \\
\text { Slime }\end{array}$ & $\begin{array}{l}17.9 \\
22.9\end{array}$ & $\begin{array}{l}22.1 \\
30.1\end{array}$ & $\begin{array}{l}25.6 \\
30.0\end{array}$ & $\begin{array}{l}27.0 \\
31.5\end{array}$ & $\begin{array}{l}31.8 \\
34.1\end{array}$ & $\begin{aligned} 11.2 \\
12.4\end{aligned}$ \\
\hline \multicolumn{7}{|c|}{ Percent Uranium } \\
\hline $\begin{array}{l}\text { Pebble } \\
\text { Concentrate } \\
\text { Slime }\end{array}$ & $\begin{array}{r}0.007 \\
.006\end{array}$ & $\begin{array}{r}0.009 \\
.008\end{array}$ & $\begin{array}{r}0.014 \\
.011\end{array}$ & $\begin{array}{r}0.013 \\
.010\end{array}$ & $\begin{array}{r}0.016 \\
.012\end{array}$ & $\begin{array}{r}0.008 \\
.020\end{array}$ \\
\hline \multicolumn{7}{|c|}{$\mathrm{CaO}: \mathrm{P}_{2} \mathrm{O}_{3}$} \\
\hline $\begin{array}{l}\text { Pebble } \\
\text { Concentrate } \\
\text { Slinee }\end{array}$ & $\begin{array}{l}3.15 \\
2.67\end{array}$ & $\begin{array}{l}1.62 \\
1.47\end{array}$ & $\begin{array}{l}1.69 \\
1.37\end{array}$ & $\begin{array}{l}1.47 \\
1.39\end{array}$ & $\begin{array}{l}1.32 \\
1.38\end{array}$ & 0.61 \\
\hline \multicolumn{7}{|c|}{$\mathbf{F}: \mathbf{P}_{2} \mathrm{O}_{6}$} \\
\hline $\begin{array}{l}\text { Pebble } \\
\text { Concentrate. } \\
\text { Slime. }\end{array}$ & $\begin{array}{r}0.119 \\
.115\end{array}$ & $\begin{array}{r}0.114 \\
.110\end{array}$ & $\begin{array}{r}0.114 \\
.112\end{array}$ & $\begin{array}{r}0.114 \\
.114\end{array}$ & $\begin{array}{r}0.108 \\
.110\end{array}$ & $\begin{array}{r}0.079 \\
.052\end{array}$ \\
\hline
\end{tabular}

1 The $-35+150$ mesh feed fraction was separated, by flotation, into a concentrate and sand tailings fraction. No concentrate was present in the samples from the aluminum phosphate zone in the Bone Valley formation.

Phosphorite of the Bone Valley is here divided into those deposits characterized by black phosphate nodules and those characterized by lighter colored nodules (white, tan, and gray). The darker material contains a high pebble percentage and a lower concentrate fraction than the unnamed sand and limestone unit or the lighter material of the Bone Valley. Also, the slime fraction of the darker material is low, half as much as in the lighter material. The aluminun. phosphate zone is characterized by a very minor pebble fraction, high sand percentage, no concentrate fraction, and a medium slime fraction. 
Several generalizations about the phosphate content of the nodules in the different stratigraphic units can be made: First, the pebble fraction always has less phosphate than the concentrate fraction; second, the phosphate content of the aluminum phosphate zone is only about half that of the calcium phosphate zone; and third, the phosphate content of the nodules is highest in the Bone Valley, and gets progressively lower in the unnamed unit and the clastic rock of the Hawthorn, and is lowest in the limestone of the Hawthorn.

The uranium content also varies in a more or less regular manner and follows the variations in phosphate content. In general, the uranium content of the phosphate nodules is greater in the coarser fraction, is higher in the calcium phosphate zone of the Bone Valley and unnamed unit than in the clastic rock of the Hawthorn, and the limestone of the Hawthorn contains the least amount of uranium. It is also notable that the highest average uranium content is found in the slime fraction of the aluminum phosphate zone.

The ratio of calcium to phosphate is lowest in the aluminum phosphate zone, increases regularly through the Bone Valley, the unnamed sand and limestone, and clastic rock of the Hawthorn, and is greatest in the limestone of the Hawthorn. This change in ratio corresponds to a change in mineralogy-from aluminum phosphate to calcium phosphate to calcium phosphate plus calcite. It is also interesting to note that the ratio is generally higher in the pebble fraction than in the concentrate fraction. The ratio of calcium to phosphate in fluorapatite (Palache, Berman, and Frondel, 1951) is slightly more than 1.3, and only those samples highest in phosphate, (the pebble fraction of the light phosphate of the Bone Valley, the concentrate fractions of the Bone Valley and the unnamed unit) approach this theoretical ratio. All of the other samples contain an excess of calcium.

The ratio of fluorine to phosphate is less than 0.1 only in the samples of the aluminum phosphate zone, is about the same for all of the samples of the calcium phosphate zone, and is slightly higher in the samples from the limestone of the Hawthorn. Fluorapatite has a theoretical ratio slightly in excess of 0.10 . The pebble fraction of the light phosphate of the Bone Valley formation approaches this theoretical ratio most closely; it is also these samples that are closest to the theoretical ratio of calcium to phosphate for fluorapatite.

\section{WEATHERING}

Intense weathering has altered the rocks in the land-pebble district, apparently several times. Lack of fossils, and the similarity of the rock types make it difficult to separate the different weathering cycles. The unconformable relations between the Bone Valley and the Haw- 
thorn formations cannot be demonstrated from the drilling, but these relations have been noted in mining pits where basal phosphorite conglomerates of the Bone Valley rest directly on the irregular, eroded surface of limestone or dolomite of the Hawthorn formation. It seems likely that a period of weathering followed the deposition of the Hawthorn. This weathering dissolved the calcium carbonate, leaving behind a residuum enriched in phosphate particles. The transgressing sea of the Bone Valley reworked this residuum and deposited the Bone Valley formation on the irregular karst topography of the Hawthorn. It has been noted that the limestone of the Hawthorn has been dolomitized close to the surface. That this dolomitization took place after the deposition of the Bone Valley formation is indicated by the fact that the phosphate particles of the Bone Valley, many of which are phosphatized limestone, contain no magnesium; complete analyses show that phosphate particles average less than 0.3 percent $\mathrm{MgO}$, whereas the limestone of the Hawthorn may contain 20 percent $\mathrm{MgO}$ or more. Weathered sections of the Hawthorn (the thicker sections of calcareous bedclay) are close to and apparently related to the present land surface. Deeper beds in the Hawthorn are fresh, unweathered rocks. Therefore, it is believed that the residuum formed on the surface of the Hawthorn prior to the deposition of the Bone Valley formation, may have been entirely reworked into the Bone Valley.

The intense weathering that formed the aluminium phosphate, or leached zone, took place after the deposition of the Bone Valley. This zone of alteration underlies and is older than the surficial soil profile, a ground-water podzol, typified by the acid Leon soil, (Fowler and others, 1927, p. 11). Plate 21 illustrates the typical soil profileloose light-gray surficial sand, overlying a dark-brown to black ironcemented and organic sand. Below this layer the sands are loose and stained brown by iron.

The alteration is generally confined to the upper part of the Bone Valley formation and to the top of the lower part, although there is some aluminum phosphate as low in the stratigraphic section as the Hawthorn formation, (pl. 16); and even the Tampa (pl. 32). The alteration changed calcium phosphate minerals to aluminum phosphate minerals, and the dominant clay mineral from montmorillonite to kaolinite. It is possible that in addition this period of weathering also altered the limestone of the Hawthorn to a dolomite and, by continued leaching, changed the limestone to calcareous clay. The formation of the surficial soil profile is the last episode of the weathering, and presumably occurred during one or more of the Pleistocene withdrawals of the sea. 


\section{ECONOMIC GEOLOGY}

Two zones of economic significance are shown on the cross sections (pls. 16-33) by stippled patterns. These zones are the calcium phosphate zone or "matrix", and the aluminum phosphate or "leached" zone. Neither term is used in a stratigraphic sense; both zones cut across the stratigraphic units. (See pl. 25, holes 11-13.)

\section{CALCIUM PHOSPHATE ZONE}

The calcium phosphate zone is that part of the stratigraphic section characterized by nodules or particles of carbonate fluorapatite (Altschuler and Cisney, 1952). This zone is nearly synonymous with the "matrix", which is that part of the section which can be mined profitably under existing economic conditions. The calcium phosphate zone may be entirely within the lower unit of the Bone Valley formation, or it may be entirely the residual Hawthorn (the calcareous bedclay), or a combination of the two.

Many of the drill holes bottomed in formations older than the Hawthorn. In many of the holes, sections of core from the Hawthorn contained phosphate nodules. These sections of phosphatebearing Hawthorn are not included in the calcum phosphate zone when they are separated from the lower, phosphatic unit of the Bone Valley formation by barren clay or sandy clay. The phosphate-bearing calcareous clay of the Hawthorn formation is considered a part of the calcium phosphate zone only when it immediately underlies the Bone Valley formation, and is close enough to the surface to be mined. The calcium phosphate zone as used in this report is not synonymous with "matrix" because some of the factors necessary for deciding whether a given drill hole contains economic phosphate could not be computed. Factors that must be considered in separating economic from noneconomic phosphate are (1) thickness of waste material (overburden) above the zone (computed in cubic yards of material removed to recover one ton of product); (2) amount of recoverable phosphate (computed in tons per acre); (3) amount of waste material in the phosphatic zone (computed in cubic yards of matrix per ton of product) ; (4) $\mathrm{P}_{2} \mathrm{O}_{5}$ content of the phosphate particles (computed as percent of bone phosphate of lime-BPL); (5) thickness of the zone in feet; and (6) total combined iron and alumina, in percent. If any of these factors are above the maximum allowable limit, or below a given minimum limit, the deposit is probably not minable. Because each active company in the district has slightly different standards for each factor, the figures given below are approximate. 
Economic factors

Cubic yards overburden per ton of recoverable product.Cubic yards matrix per ton of recoverable product.

Thickness (in feet) of matrix bed.

Tons per acre foot of recoverable product.

Percent $\mathrm{BPL}^{1}$ (percent $\mathrm{P}_{2} \mathrm{O}_{5} \times 2.185$ )

Percent combined iron and alumina.

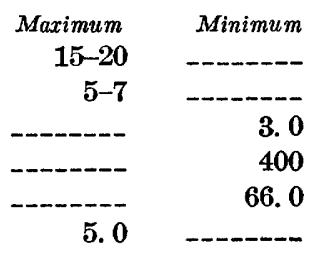

1 BPL, bone phosphate of lime.

These factors are not absolute. For example, a deposit containing only 66 percent BPL must have a smaller factor of cubic yards per ton and a greater factor of tons of product per acre than a deposit containing 75 percent BPL. In addition, a single drill hole might contain some factors that were not economic, but if located in an area containing better than average material, it would be mined if the average of the larger area was economic. To block out a deposit 16 holes per 40 acres are drilled, or 1 hole in each 2.5 -acre block. The area of a standard drill hole is about one-millionth of the area of the 2.5-acre block. Thus, the accuracy of tonnage and grade estimates for this drilling is extremely low, and tonnage and grade figures are not projected, but are given only in tons per acre, or cubic yards per acre.

\section{ALUMINUM PHOSPHATE ZONE}

The aluminum phosphate zone is that part of the section that has been strongly altered by acid ground waters. The zone is characterized by the presence of aluminum phosphate minerals, kaolinite, and generally, by the highest uranium content as indicated by the high peaks on the gamma-ray logs. The alteration is generally confined to the upper part of the Bone Valley formation and the top of the lower part, although aluminum phosphate minerals were developed as low as the Hawthorn (pl. 16) or the Tampa (pl. 32). The zone can be identified by some or all of the following features: Vesicularlike texture, secondary cements, white color, low specific gravity, and indurated or friable character.

Factors concerned in the economics of the aluminum phosphate zone are more uncertain than those for the calcium phosphate zone because so little is known as to the possible processes that may be used to recover the various materials in the zone. For example, any one or combination of three products-phosphate, alumina, and uranium-might be obtained from this zone. For purposes of this report, it is assumed that phosphate and uranium will be recovered, and that alumina will not be a product. The lines of possible economic correlation on the cross sections are drawn on this assumption. If alumina should be recovered as a third product, some of the upper clayey sand that has been excluded from the aluminum phosphate 
zone on the cross sections may become economic. However, because the clayey sand is low in uranium, it was not analyzed for phosphate or alumina. Therefore, it is not possible to say whether it contains enough alumina or phosphate to be economic.

If the above assumptions are correct, the factors that affect the economics of the aluminum phosphate zone are (1) thickness of the waste material above the zone, (2) thickness of the zone, (3) phosphate and uranium content of the zone in percent, (4) $\mathrm{CaO}$ and $\mathrm{Al}_{2} \mathrm{O}_{3}$ content of the zone in percent, and (5) whether economic calcium phosphate zone underlies the aluminum phosphate zone. At present, all mining of the zone must be integrated with the mining plans of the active companies for the phosphate matrix. As indicated on figure 26, fringe areas to the west and northwest of the central part of the land-pebble district are underlain by aluminum phosphate zone, which is not underlain by matrix.

An absolute figure for excessive overburden thickness cannot be given. However, because the digging depth of the largest draglines is about 70 feet, more than about 50 feet of waste material overlying the zone would be excessive.

The cutoff value of contained $\mathrm{P}_{2} \mathrm{O}_{5}$ has been arbitrarily placed at 5 percent, principally because large areas contain aluminum phosphate zone with more than 5 percent $\mathrm{P}_{2} \mathrm{O}_{5}$, and other large areas are underlain by clayey sand that contain less than 5 percent $\mathrm{P}_{2} \mathrm{O}_{5}$.

A lower limit of 0.005 percent uranium has been chosen because most of the samples above this value had high contents of uranium in the slime fraction (in which the aluminum phosphate minerals are concentrated). The uranium content of the slime fraction tends to be greater than 0.010 percent in samples where the head assays range from 0.005 to 0.010 percent uranium. Conversely, in samples where the head assay is less than 0.005 percent uranium, the slime fractions tend to be less than 0.005 percent.

Little is known about the effect of high or low $\mathrm{CaO}$ content, but processing costs possibly could rise with high calcium.

If the final product is to be a fertilizer, a high alumina content could be somewhat less desirable than a lower content, but it is not possible to evaluate the effect of varying alumina content.

\section{GENERAL RELATIONS}

The index map (fig. 26) shows the location of the drill holes, the limits of the calcium phosphate zone, and the limits of the aluminum phosphate zone. The limits of the phosphate zones are based only on the 115 drill holes shown. Figure 26 shows that to the northwest the aluminum phosphate zone extends beyond the limits of the calcium phosphate zone (see cross sections $1,4,17$, and 18), and that the 
aluminum phosphate zone apparently extends farther south, in Hardee and Manatee Counties, than was previously known. This extension is based on cross sections 9 and 10, and because of limited data it is possible that only patches of aluminum phosphate zone are present in this area. East and south the calcium phosphate zone extends beyond the limits of the aluminum phosphate zone. The difference in position of the two zones may be explained by the facts that (1) in the northwest, phosphate deposition was thinnest, the entire calcium phosphate zone apparently was leached, so that only remnants of it remain, and (2) where the Bone Valley formation was thicker to the south, only the top part of the formation was leached, and hence both zones are still present. Still farther south, in Hardee and Manatee Counties, the formation may not have been exposed to subaerial weathering, and no aluminum phosphate zone was formed. (See discussion of cross sections 7, 8, and particularly, 9.) The limit of the aluminum phosphate zone on the east coincides approximately with the present topographic ridge to the east of the Peace River. The land east of the ridge, which is lower in elevation than the land to the west, also probably was not exposed to subaerial weathering. The present limit is the result of a combination of two factors: (1) erosion after the zone was formed, and (2) the possibility that somewhere to the east the phosphatic sediments were not exposed to weathering.

\section{SUGGESTIONS FOR EXPLORATION}

The area east of R. 26 E. even though there may be some leached material present, is deeply buried by barren sand of the overburden, and is not a good area for exploration. The most promising areas for exploration, based on the results of this drilling program, are first, the area to the northwest in Hillsborough and Pasco Counties, where the aluminum phosphate zone is not underlain by economic matrix, and second, the area to the south, in Hardee and Manatee Counties, where extensive deposits may be present. This latter area has not been extensively explored by the private companies because of the low grade of the phosphate nodules in the matrix. It is most probable that the area is not entirely underlain by aluminum phosphate zone, but in some localities, particularly adjacent to the Peace River, aluminum phosphate zone material may be present. Results of scattered drilling west of the Peace River, in Hardee and Manatee Counties, indicate that patches of the aluminum phosphate zone are present. This area should be explored further if it becomes necessary to outline reserves of the aluminum phosphate zone more fully. The remainder of the district, in Polk and Hillsborough Counties, probably has been well- 
enough explored by private companies at least for preliminary estimates of tonnage and grade.

\section{DISCUSAION OF CROSS SECTIONS}

A summary of the lithologic characteristics used in stratigraphic correlation is given below. The table shows, for example, that the clastic rocks of the Hawthorn formation are loose sand, clayey sand, calcareous clay, and green or blue sandy or silty clay, all containing phosphate particles low in $\mathrm{P}_{2} \mathrm{O}_{5}$ content. The clastic rock of the Hawthorn contain more phosphate particles and fewer chert fragments than the clastie rock of the Tampa. The criteria as shown on the table are not invariable, but are in general characteristic of the formations. For example, chert fragments do not always occur in the clastic rock of the Tampa limestone, and occasional chert fragments, or silicified fossil fragments are found in the Hawthorn formation. However, chert fragments in a calcareous clay overlying fossiliferous Suwannee limestone (pl. 16) was considered enough evidence to classify this material as Tampa.

Cross sections 1-18 are shown on plates 16-33. All analytical data and results of screen-size analysis and tonnages and uranium contents are given at the end of the report.

\section{CROSS SECTION 1}

\section{STRATTGRAPHY}

Suwannee.-Fossils from the bottom of hole 4 were identified as Oligocene in age. Hole 5 was bottomed in a very hard bed, probably siliceous limestone, that is correlated with the Suwannee limestone of hole 4.

Tampa.-Fossils from the bottom of hole 3 were identified as early Miocene in age. In addition, the sandy calcareous clay from sample 13 (see p. 211) contained no phosphate particles, and is included in the Tampa. The limestone in holes 1 and 2 is lithologically identical with that in hole 3 and is thus correlated. In holes 1, 2, and 4 , the calcareous clay above the limestone contains chert fragments, limestone fragments, and very sparse phosphate nodules; this material is tentatively called Tampa.

Hawthorn.-Green silty clay, calcareous clay, and sand, all of which contain phosrhate nodules, overlie the sandy clay of the Tampa limestone in holes 1-3. These materials are tentatively correlated with the Hawthorn formation. The contact between the Hawthorn and the Bone Valley is marked in holes 1-3 by a green silty clay underlain by a bed of quartz sand containing amber phosphate nodules. The Hawthorn formation pinches out to the north; apparently it is not represented in holes 4 and 5. 


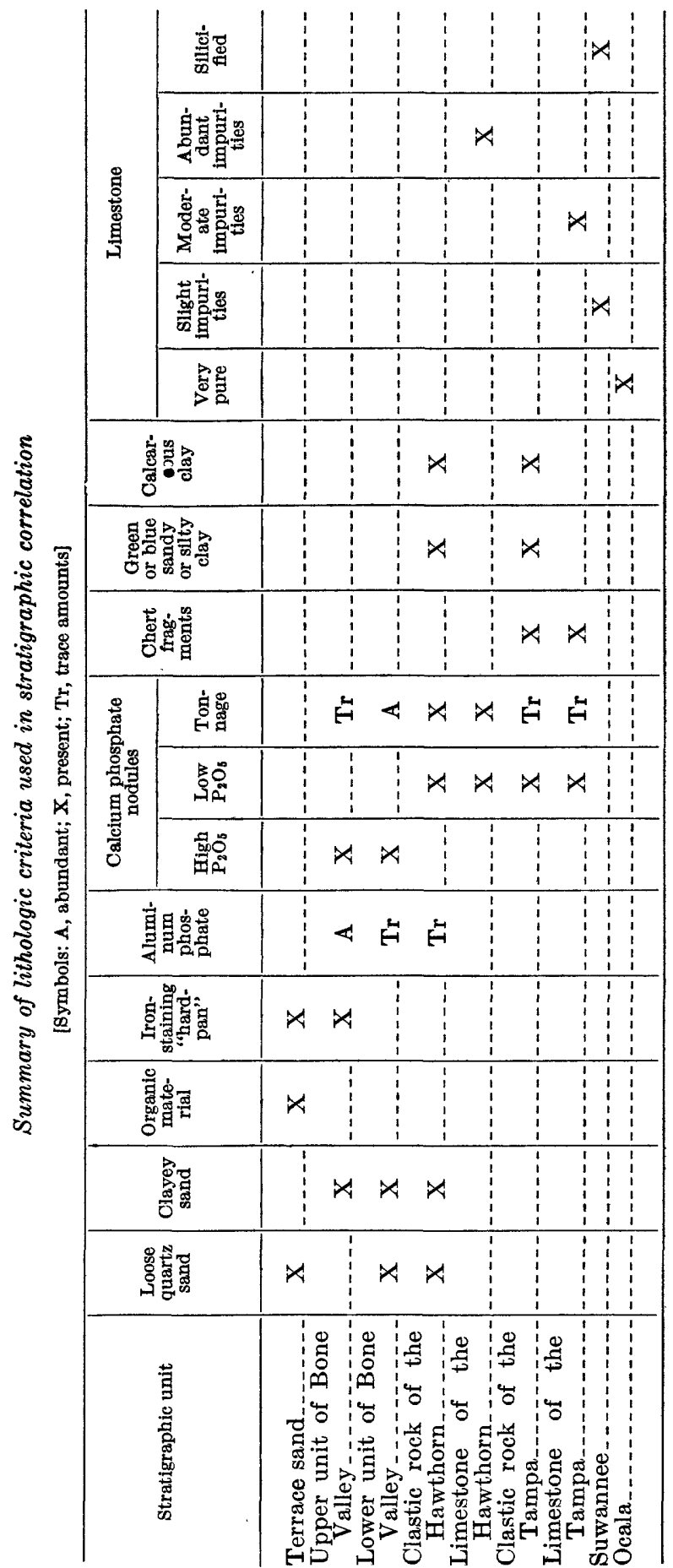


Bone Valley.-Slightly clayey sand overlies the green clay of the Hawthorn formation in holes 1 and 3, the calcareous clay of the Tampa limestone in hole 4, and the hard material on which hole 5 was bottomed. Phosphate sand is between the clayey sand and the green clay of the Hawthorn formation in hole 2. The clayey sand and the phosphate sand are believed to be Pliocene in age and equivalent to the Bone Valley formation.

Terrace sand.-White loose quartz sand overlies the iron-stained clayey sand in each drill hole. These surficial sands are lithologically alike and are believed to be of Pleistocene age.

\section{ECONOMIC GEOLOGY}

The calcium phosphate zone was cut only by hole 2 , where it is thin, low grade, low in tonnage (see p. 287), and not economic. Small amounts of phosphate nodules, low in $\mathrm{P}_{2} \mathrm{O}_{5}$ content were found in samples of the Hawthorn formation from holes 1 and 3 ; because of excessive depth, low tonnage, and low grade, these samples are not included in the calcium phosphate zone.

The aluminum phosphate zone was penetrated by holes 1-4. The thick section of clayey sand in hole 5 probably contains some aluminum phosphate minerals, but the content is too low for the sand to be an economic source of phosphate and uranium.

\section{CROSS SECTION 2}

\section{STRATIGRAPHY}

Sunvannee.-Fossils from the limestone of hole 4 were identified as Oligocene in age. The hard material at the bottom of hole 3 is tentatively correlated with the Suwannee because fossils of early Miocene age were found above the hard material. The Suwannee was probably not intersected in drill holes 1 and 2.

Tampa.-Casts and molds of fossils identified as early Miocene in age were found in a thin bed of siliceous material cut by hole 3. Although it is possible these fossils are reworked, the lithology of the material in which they were found is similar to the lithology of the core from hole 4 that overlies the Suwannee.

Hawthorn.-The green silty clay, sandy clay, and clayey sand, all of which contain phosphate grains, are called Hawthorn on the basis of lithologic character. In holes 1,3 , and 4 these materials overlie material assigned to the Tampa for the same reason. The Hawthorn is thickest at hole 1 and is a little thinner to the northwest.

Bone Valley.-The Bone Valley formation is thickest at hole 1, and thins northwestward to hole 4, except that at hole 2 , in the sink hole, the formation is even thicker than in hole 1 , and the base was not reached. The calcium phosphate zone is present at holes 2 and 
3 , is absent at hole 4 , and may be present at hole 1 , in the section of core that was not recovered.

White, gray, or brown (iron stained) clayey sand form the upper part of the Bone Valley formation at holes 1-3. At hole 4 all the Bone Valley present is clayey sand, lithologically similar to the clayey sand of holes 1-3.

Terrace sand.-The base of the Pleistocene at hole 1 is put at the base of the highly organic sand. The great thickening of the section at hole 2 is due to the filling of a sink hole. The base of the Pleistocene at holes 3 and 4 is the contact of the loose, surficial sand with the clayey sand of the upper part of the Bone Valley.

\section{ECONOMIC GEOLOGY}

Although the calcium phosphate zone is present at holes $1-4$, no economic material is present. Samples 21 and 22 (see p. 272) from hole 1 contain calcium phosphate nodules, but they are low in grade, low in tonnage, and are covered by too great a thickness of barren material (overburden) to be economic, therefore, this material is not considered a part of the calcium phosphate zone.

The aluminum phosphate zone, a part of the clayey sand of the upper part of the Pliocene Bone Valley formation, varies in its position in the section. It forms the bottom part of the clayey sand at holes 1 and 2, the upper part the clayey sand at hole 3 , and at hole 4 the entire zone of clayey sand is possibly aluminum phosphate zone. The highest gamma-ray peak, $2700 \mathrm{cpm}$ (counts per minute), in the aluminum phosphate zone is in hole 1 . In hole 2 the high peak is greater than $1800 \mathrm{cpm}$, in hole 3 it is less than $1800 \mathrm{cpm}$, and in hole 4, the high peak barely reaches $900 \mathrm{cpm}$. Thus, in the concentration of uranium there seems to be a decrease northwestward and toward the fringe of the district.

\section{CROSS SECTION 3}

\section{STRATIGRAPHY}

Tampa.-Early Miocene fossils were found in limestone fragments in sandy clay in the bottom of hole 2. Lithologically similar material from holes 1 and 3-5 is considered a part of the Tampa. No fossils were found in the limestone cores from holes 1 and 3-5, but this limestone is lithologically like the limestone of the Tampa and is tentatively correlated with the Tampa.

Hawthorn.-Green sandy clay and clay, in part containing nodules of calcium phosphate, are tentatively correlated with the Hawthorn. The contact of the Hawthorn with the underlying Tampa at hole 2 is the base of the phosphate-bearing clay, with a somewhat different 
fossiliferous sandy clay lying below. The Hawthorn formation thins: westward.

Bone Valley.-The Bone Valley formation at hole 1 consists of an upper unit of clayey sand that contains a few soft white phosphate nodules, and a lower phosphorite unit that contains abundant coarse phosphate. At holes 2 and 3-5, the lower unit is not present, and the Bone Valley is represented by white or tan clayey sand, which probably contains some aluminum phosphate minerals. The clayey sand is lithologically similar in all holes.

The top of the Bone Valley at hole 3 is marked by a gray clay bed. This clay is not like any other clay bed in the cross section.

Terrace sand.-Loose gray, tan, or white quartz sand overlies the clayey sand of the upper part of the Bone Valley in all drill holes. This sand is tentatively classed as Pleistocene.

\section{ECONOMIC GEOLOGY}

The calcium phosphate zone was penetrated only by hole 1 , where it is thin, but very high in $\mathrm{P}_{2} \mathrm{O}_{5}$ content. (See p. 272.) The analyzed material from hole 4 (sample 35) is high enough in $\mathrm{P}_{2} \mathrm{O}_{5}$ content to. be a part of the calcium phosphate zone, but tonnages are very low, therefore it is not included in the calcium phosphate zone. The phosphate-bearing material from hole 3 was not analyzed; visual inspection of the core indicated that only noneconomic amounts of phosphate were present.

The aluminum phosphate zone, at holes 1 and 2, at the top of the section of clayey sand, was delineated by analysis and by the high radioactivity shown on the gamma-ray logs. The clayey sand of holes $3-5$, analyzed only from hole 4 , is too low in uranium content and probably in phosphate content to be economic, although aluminum phosphate minerals are probably present. The material, therefore, is not included in the aluminum phosphate zone.

\section{CROSS SECTION 4}

\section{STRATIGRAPIIY}

Tampa.-Fossils from the limestone cores at the bottom of holes 1 and 3 were identified as early Miocene in age. A zone of ironstained and cemented, laminated sandy clay at hole 1 occurs above the limestone. The lithology of this material does not resemble anything in the Hawthorn, so this sandy clay is very tentatively correlated with the Tampa.

Hawthorn.-The limestone at the bottom of hole 2 contained fossils identified as probably middle Miocene. The green sandy clay above the Tampa at hole 1, plus the phosphate-bearing sandy clay of sample 41, are tentatively correlated with the Hawthorn. The 
phosphate-bearing calcareous clay from hole 3 together with the calcareous clay above it are put into the Hawthorn.

Bone Valley.-Lower Bone Valley was penetrated by holes 1-3. At hole 1, the contact of the Bone Valley with the Hawthorn is at the top of the sandy clay of sample 41, which contains nodules of lower $\mathrm{P}_{2} \mathrm{O}_{5}$ content than the clayey sand of sample 40 (see p. 273). The lower unit of the Bone Valley rests on limestone of the Hawthorn at hole 2. The contact between the units is sharp; the phosphorite above the contact is bedded and noncalcareous. At hole 3, the lower unit of the Bone Valley rests on green calcareous sandy clay of the Hawthorn. The upper clayey sand of the Bone Valley is present at holes 1 and 2, but is absent at hole 3, where highly carbonaceous sand rests directly on the lower unit of the Bone Valley.

Terrace sand.-The loose slightly iron-stained and highly organic sand at the surface is tentatively correlated with the Pleistocene.

\section{ECONOMIC GEOLOGY}

Possibly economic calcium phosphate zone was penetrated by all drill holes in this line (see p. 288). The calcium phosphate zone at holes 1 and 3 is made up of the lower unit of the Bone Valley formation and the phosphate-bearing beds of the Hawthorn formation. However, the entire calcium phosphate zone at hole 2 is represented by the lower unit of the Bone Valley formation.

Possibly economic aluminum phosphate zone material was penetrated only in hole 1, where it is delimited by the gamma-ray log. Hole 2 penetrated clayey sand of the upper Bone Valley, which probably contains some aluminum phosphate minerals. This material is not considered a part of the aluminum phosphate zone because the gamma-ray log was not above background in the interval represented by the clayey sand. Clayey sand of the upper part of the Bone Valley formation was not penetrated by hole 3 .

\section{CROSS SECTION 5}

\section{STRATIGRAPHY}

Hawthorn.-Phosphate-bearing sandy, clayey limestone at the bottom of holes 3 and 4 is correlated with the Hawthorn. Although no limestone was recovered in holes 1 and 2, the holes were bottomed on hard material that is assumed to be limestone of the Hawthorn. Calcareous, sandy, phosphatic clay overlying the limestone at hole 3, and similar clay in holes 1 and 2 are tentatively correlated with the Hawthorn.

Bone Valley.-The lower unit of the Bone Valley formation was penetrated in holes 1-3. The contact with the underlying Hawthorn 
is put at the top of the calcareous clay. Clayey sand of the upper part of the Bone Valley formation is present at all drill holes. The contact of the upper unit with the lower unit is placed at the appearance of calcium phosphate nodules.

Terrace sand.-Loose quartz sand, tentatively assigned to the Pleistocene, was cut by each drill hole. The contact with the upper Bone Valley formation is placed at the base of the iron-stained loose sand.

\section{ECONOMIC GEOLOGY}

The calcium phosphate zone is present at holes 1-3 (see p. 288). At holes 2 and 3 the zone includes phosphate deposits of both the lower part of the Bone Valley and the Hawthorn formation. The basal calcareous clay at hole 1 was excluded from the calcium phosphate zone because of probable very low tonnages. The analyzed material from hole 4, although it is not too different in phosphate content from the material in other drill holes, is excluded from the calcium phosphate zone because it is in a limestone that would be very difficult to mine and process.

The aluminum phosphate zone is present at holes 2 and 4 . The zone was delimited by the use of the gamma-ray logs. The material of sample 42, hole 1, contains aluminum phosphate minerals but was excluded from the aluminum phosphate zone because the computed head analysis would be too low in phosphate and uranium content.

\section{CROSS SECTION 6}

STRATTGRAPHY

Hazothorn.-Limestone was penetrated only by hole 3. The limestone contains abundant phosphate particles, sand, and clay and is therefore considered to be a part of the Hawthorn formation. The remaining holes in this line bottomed on a hard material from which no core was recovered. This material is tentatively considered to be limestone of the Hawthorn formation. The calcareous, sandy, phosphate-bearing clay at the bottom of each hole is considered to be Hawthorn. Except at hole 5, the phosphate particles in the calcareous clay contain very low amounts of $\mathrm{P}_{2} \mathrm{O}_{5}$.

Bone Valley.-The lower phosphorite unit of the Bone Valley is present at holes $1-3$, but is absent from holes 4 and 5 . The contact of the Bone Valley with the Hawthorn in these holes is placed at the top of the calcareous clay. In addition, the phosphate particles of the Bone Valley contain much higher amounts of $\mathrm{P}_{2} \mathrm{O}_{5}$ than the phosphate particles in the calcareous clay of the Hawthorn (see p. 274). The upper, clayey sand of the Bone Valley formation is present at all drill holes. This unit contains trace amounts of apparently un- 
leached phosphate particles at holes 3 and 4. The material is leached at holes 1 and 2 where aluminum phosphate minerals are present.

Terrace sand.-The loose surficial sand shows evidence of a typical Leon soil profile. At holes $2-5$, the loose white surficial sand is underlain by iron-stained and organic sands, which in turn is underlain by brown and tan loose sand. The contact of the Pleistocene with the Bone Valley formation is placed at the top of the clayey sand where the iron staining becomes insignificant. At hole 5 the contact is placed in the middle of the section of core that was not recovered, at the point where there is a slight rise in the gamma-ray log. This rise probably coincides with an increase in clay content.

\section{ECONOMIC GEOLOGY}

The calcium phosphate zone was penetrated by holes $1-3$, where it is entirely within the lower unit of the Bone Valley formation. Analyzed material below the calcium phosphate zone, in the Hawthorn formation, contains too little $\mathrm{P}_{2} \mathrm{O}_{5}$ to be economic; this material is therefore not considered a part of the calcium phosphate zone. (See p. 288.) Phosphate-bearing calcareous clay of the Hawthorn formation in holes 4 and 5 is excluded from the calcium phosphate zone because of excessive thicknesses of overburden and too little tonnage of phosphate.

The aluminum phosphate zone is present at holes 1,2 , and possibly at hole 3. The top contact in each of these holes is placed at the rise in the gamma-ray log; the basal contact, at the appearance of calcium phosphate particles. At hole 3, the material called aluminum phosphate zone because of the rise in the gamma-ray log contains phosphate nodules, and may be calcium phosphate zone.

\section{CROSS SECTION 7}

\section{STRATIGRAPHY}

Hawthorn.-Limestone core was recovered only from hole 4; all other holes bottomed in hard material, presumed to be limestone of the Hawthorn. Sandy, clayey, phosphate-bearing, calcareous clay at the bottom of all holes is tentatively correlated with the Hawthorn.

Bone Valley.-The lower, phosphorite unit of the Bone Valley formation was penetrated by all drill holes. The contact of the Bone Valley with the Hawthorn is the top of the calcareous clay. $\mathrm{P}_{2} \mathrm{O}_{5}$ contents of the phosphate nodules are higher above this contact than below it. The upper, clayey sand of the Bone Valley formation was also penetrated by all drill holes in this line.

Terrace sand.-Loose white surficial sand is underlain by ironstained and cemented and highly organic sand, which in turn is underlain by brown loose sand, probably forming a soil profile; these 
are tentatively assigned to the Pleistocene. The contact of the Pleistocene with the underlying Bone Valley is at the top of the clayey sand. This contact generally coincides with a rise in the radioactivity, as shown by the gamma-ray logs.

\section{ECONOMIC GEOLOGY}

The calcium phosphate zone was penetrated by all drill holes; however, stratigraphically this zone is made up of Bone Valley, Hawthorn, or both, in this section. The zone is composed of both Hawthorn and Bone Valley at holes 1-4. The entire calcium phosphate zone at hole 5 is represented by the lower unit of the Bone Valley formation.

The aluminum phosphate zone is present only at holes 1-3 where it is delimited by the high peaks on the gamma-ray logs. The high peak at hole 4 is apparently entirely within the calcium phosphate zone, and radioactivity as shown by the gamma-ray log at hole 5 is only about twice background, too low for the clayey sand to be considered possibly economic.

\section{CROSS SECTION 8}

\section{STRATIGRAPHY}

Hawthorn.-Although no limestone cores were recovered from any of the drill holes, each hole bottomed on hard material, presumed to be limestone, probably of the Hawthorn formation. The green, calcareous sandy clay and clayey sand at the bottom of holes 1, 2, and 4, are tentatively correlated with the Hawthorn, because of their high phosphate content, color, and general appearance. At hole 3, phosphorite of the Bone Valley formation rests directly on the hard material.

Bone Valley.-The lower, phosphorite unit of the Bone Valley is present at all drill holes. The material consists of quartz sand and coarse black phosphate particles, with only a small amount of clay. The screen analyses (see p. 275) show that the clay content of the Bone Valley is less than the clay content of material correlated with the Hawthorn. The upper, clayey sand of the Bone Valley formation was penetrated by holes 1 and 3, and is absent at holes 2 and 4. The upper contact of the lower unit of the Bone Valley is put at the rise in the gamma-ray log.

Terrace sand.-Loose quartz sand at the surface, iron-stained or cemented sand, and highly organic sandy clay are all tentatively correlated with the Pleistocene. Organic sand is close to the surface at holes 1 and 4, but at holes 2 and 3, a very highly organic sandy clay is at the base of the Pleistocene. 


\section{ECONOMIC GEOLOGY}

The calcium phosphate zone was penetrated by all drill holes. The coarse fraction (pebble) is invariably too low in $\mathrm{P}_{2} \mathrm{O}_{5}$ content to be economic, but the concentrate fraction is, in most of the samples, high enough in phosphate content to be considered economic. Material from both the Bone Valley and Hawthorn has been included in the calcium phosphate zone, except at hole 3 , where a thin gravel probably representing the base of the Bone Valley rests on hard material that was not recovered. Generally, the phosphate particles in the Hawthorn are somewhat lower in $\mathrm{P}_{2} \mathrm{O}_{5}$ content than are the particles in the Bone Valley.

The aluminum phosphate zone is not present in this cross section. Clayey sand of the upper part of the Bone Valley is present only at holes 1 and 3, and gamma-ray logs indicate this clayey sand contains no abnormal radioactivity. At holes 2 and 4, sand of the Pleistocene rests on the lower, phosphorite zone of the Bone Valley.

\section{CROSS SECTION 9}

STRATTGRAPHY

Hawthorn.-Limestone, assigned to the Hawthorn on the basis of lithologic character, was recovered only from hole 12; the remaining holes in this cross section bottomed on hard material, presumed to be limestone of the Hawthorn formation. Green, calcareous, clayey sand, containing phosphate nodules, was cored in each drill hole, and ranges in thickness from less than 2.0 feet in holes 1,2 , and 6 , to a maximum of about 30 feet in hole 9. The calcareous sand is tentatively correlated with the Hawthorn. Phosphate nodules in the calcareous sand contain lower amounts of $\mathrm{P}_{2} \mathrm{O}_{5}$ than the phosphate nodules in the noncalcareous sand above them.

Bone Valley and Hawthorn is shown on pages 276-277; the Hawthorn formation was penetrated by each drill hole. The unit is a quartz sand, with a high percentage of dominantly black phosphate nodules. The upper, clayey sand unit of the Bone Valley formation was also present at each drill hole, except for hole 6, where loose white sand overlies the lower unit. At the south end of the cross section, in holes 10-12, the upper unit contains traces of fresh appearing, black phosphate nodules; these nodules are not present in the upper zone in holes 1-9. This may indicate that the clayey sand in the south end of this cross section was not leached.

Terrace sand.-Loose white quartz sand, iron stained in holes 2, 3, and $8-12$, is tentatively correlated with the Pleistocene. 


\section{ECONOMIC GEOLOGY}

The calcium phosphate zone was penetrated by each drill hole in cross section 9. The zone ranges in thickness from about 8 feet at hole 11, to 41 feet at hole 9 , and includes phosphate of both the Bone Valley and Hawthorn formations. Phosphate of the Bone Valley was penetrated by every hole, but the calcareous clayey sand of the Hawthorn was not included in the calcium phosphate zone in holes $2,7,8$, and 10 , because of the low content of $\mathrm{P}_{2} \mathrm{O}_{5}$ in the phosphate nodules. The variation in phosphate content of the nodules in the Bone Valley and Hawthorn is shown on pages 276-277; the Hawthorn contains a higher percentage of concentrate fraction than does the Bone Valley. The ratio of pebble to concentrate fraction in the Bone Valley formation is always more than one; while in the Hawthorn the ratio is lower, and in most cases is less than one. In general, the phosphate content of the nodules is highest at the north end of the section, decreases to the south, to hole 11 , where there is a rise in phosphate content. The reasons for this variation are not immediately apparent.

The aluminum phosphate zone is present at holes 1-9, except for hole 6, where no clayey sand is present, and loose sand of the Pleistocene is in contact with the lower unit of the Bone Valley formation. This may represent an old stream channel, where the clayey sand of the upper Bone Valley was removed by erosion. At holes 10-12, the upper, clayey sand unit of the Bone Valley contains small to trace amounts of apparently unleached phosphate nodules; no aluminum phosphate minerals are present in the clayey sands. In the area of these holes, the Bone Valley formation apparently was not subjected to weathering. No samples of the aluminum phosphate zone were analyzed, the zone is delimited entirely by the gamma-ray logs; the upper contact is placed at the sharp rise in radioactivity (pl. 24). The lower contact of the zone is put at the point where phosphate nodules become abundant and high in $\mathrm{P}_{2} \mathrm{O}_{5}$ content, as shown by analysis. (See p. 276.) The zone is thickest at hole 1, gradually decreases in thickness to hole 6, and then increases again in hole 7. The zone is more or less constant in thickness in holes 7-9, and is absent in holes 10-12.

\section{CROSS SECTION 10}

\section{STRATIGRAPHY}

Hawthorn.-The limestone, which was cored at most drill holes but contained identifiable fossils only at hole 8, is classed as Hawthorn because of its high phosphate content and abundant sand and clay impurities. The light-green calcareous clayey sand or sandy clay con- 
taining a high percentage of fine-grained typically amber or black phosphate nodules is tentatively correlated with the Hawthorn. The calcareous sandy clay is present at holes $1-12$, but is absent at holes. 13-16, where the only material assigned to the Hawthorn is the basal limestone.

Unnamed sand and limestone.-Fossils from limestone in hole 14 were classed as late Miocene(?). (See fossil list, p. 232.) A darkolive-green to gray calcareous, clayey, micaceous sand in holes 12,13 , 15 , and 16, is lithologically similar to fossiliferous sand of the unnamed unit in cross section 12 , hole 6 and cross section 15 , hole 6 . Thus this sand is tentatively correlated with the unnamed unit. This sand is not lithologically like any other material in cross section 10. The material also contains shell fragments, which were not identifiable.

Bone Valley.-The lower, phosphate-bearing unit was penetrated by drill holes 1-14. It is a noncalcareous clayey sand and typically contains white or gray phosphate particles that tend to be coarser in size than the amber phosphate material of the Hawthorn. The upper, clayey sand unit of the Bone Valley was penetrated by all drill holes. It thickens somewhat on the topographic highs (see holes 3 and 6, pl. $25)$ and is somewhat thicker in the southern part of the section. The material is white and slightly clayey and the quartz sand fraction tends to be somewhat coarser than the material below or above it. The color of the clay in the unit tends to become darker toward the south.

Terrace sand.-Loose quartz sand tentatively correlated with the Pleistocene was penetrated by each drill hole. Organic material below the loose sand was also, and rather arbitrarily, placed in the Pleistocene, as was done in other lines of drill holes.

\section{ECONOMIC GEOLOGY}

The calcium phosphate zone was penetrated by drill holes 1-14. (See p. 278.) The zone is made up of both Bone Valley and Hawthorn in roughly equal amounts at holes 1-10. However, at hole 11, the calcareous clay of the Hawthorn makes up the entire calcium phosphate zone; at hole 12 , only the top part of the calcareous clay contains enough phosphate of high enough grade to be possibly economic; at holes 13 and 14, the entire calcium phosphate zone is within the Bone Valley formation; and at holes 15 and 16, where the lower unit of the Bone Valley formation and calcareous clay of the Hawthorn formation were not penetrated, the phosphate-bearing material is assigned to the unnamed unit and it is much too low in tonnage and percent $\mathrm{P}_{2} \mathrm{O}_{5}$ to be economic. This cross section (pl. 25) is a good example of the crossing of stratigraphic lines by the calcium phosphate zone, particularly between holes 12 and 13 . 
The aluminum phosphate zone was present at all holes in this cross section except for holes 13 and 15, where the clayey sand, as shown by the gamma-ray logs, was not abnormally radioactive. Samples of the aluminum phosphate zone were taken from a few of the cores, but in general, the zone is delimited, at the top, by the rise in the gamma-ray log, and at the base, by the contact with the calcium phosphate zone.

\section{CROSS SECTION 11}

\section{STRATIGRAPHY}

Hawthorn.-Fossils from limestone cores at the bottom of holes 1,5 , and 6 were identified as middle Miocene in age. Limestone cored in the other holes is lithologically similar to the fossiliferous material and is correlated with the Hawthorn. Green calcareous sandy clay containing phosphate nodules overlies the limestone at holes $1,2,7$, and 8 , and is tentatively correlated with the Hawthorn. The contact of the Hawthorn with the Bone Valley formation is put at the top of the calcareous clay at holes 1 and 2, and at the top of the limestone at holes 3,4 , and 5 .

Unnamed sand and limestone.-Dark-olive calcareous sandy clay, containing black phosphate nodules and mica flakes, is lithologically similar to the fossiliferous beds of the unnamed unit in cross sections 12 and 15, and is tentatively correlated with that unit. This material is present at holes 6-8.

Bone Valley.-The lower, phosphorite unit of the Bone Valley formation is present at holes 2-5. The lower unit overlies calcareous clay of the Hawthorn at holes 1-3, and limestone of the Hawthorn at holes 4 and 5. The lower unit is absent at holes 1 and 6-8.

The upper unit of the Bone Valley formation was penetrated by all drill holes. It is thinnest at hole 1 , thickens markedly at hole 2, and remains thick in the other holes of this line. The lower part of the upper unit contains traces of phosphate nodules at holes 3 and 5-8. The contact of the lower unit with the upper unit of the Bone Valley formation is put at the point below which the phosphate content rises sharply.

Terrace sand.-Loose surficial iron-stained quartz sand, containing organic material, is tentatively correlated with the Pleistocene. This sand is present at all drill holes.

\section{ECONOMYC GEOLOGY}

The calcium phosphate zone is absent from holes 1 and 8 ; in the remaining holes it represents different stratigraphic intervals. For example, at holes 2,4 , and 5 , the calcium phosphate zone is the lower unit of the Bone Valley formation; at hole 3 it is both Bone Valley 
and Hawthorn; and at holes 6 and 7 it is the lower part of the unnamed sand and limestone unit.

The zone is economic in holes 2 and 3, but because of low grade, is questionably economic in holes 4 and 5 . The zone is covered by thick overburden at holes 6 and 7, and is also very low grade, particularly in the pebble fraction (see p. 281). For these reasons, the zone is probably not economic at holes 6 and 7 .

The aluminum phosphate zone is present at holes $2-4$, but is thin, and is high in the section of clayey sand of the upper unit of the Bone Valley formation. It is therefore, probably not economic in these holes. The zone was delimited by the use of the gamma-ray logs in all of these holes. The analyzed samples are too low in uranium content to be economic. The phosphate content of the slime (D) fraction of samples 49,52, and 54 is high, which indicates the presence of aluminum phosphate minerals. It is possible that the thick sections of clayey sand in these drill holes could be economic for alumina, phosphate, and uranium, if the three-product process is used.

\section{CROSS SECTION 12}

\section{STRATIGRAPHY}

Hawthorn.-Fossils, identified as middle Miocene in age, were identified from limestone cores at holes 1 and 8 , and from a conglomerate at hole 6 . Limestone cored at holes 2 and 3 is assigned to the Hawthorn on the basis of lithologic character, and holes 4 and 6 bottomed on hard material presumed to be limestone of the Hawthorn. Green calcareous sandy clay, containing abundant phosphate, was intersected by holes 1-4, and is tentatively correlated with the Hawthorn. The contact of the Hawthorn with the lower unit of the Bone Valley at holes $1-4$ is placed at the top of the calcareous clay. The contact of the Hawthorn with the unnamed sand and limestone unit is located on fossil evidence at the top of the limestone at hole 8 ; at hole 6 , it is put at the contact of the fossiliferous conglomerate of the Hawthorn with the olive-green calcareous clayey sand.

Unnamed sand and limestone.-Fossils, identified as late middle Miocene in age, were found at hole 8 in an olive-green slightly calcareous clayey sand that contained flakes of mica and low-grade black phosphate nodules. This clayey sand is assigned to the unnamed sand and limestone unit. Lithologically similar material overlies the conglomerate at hole 6 ; this material is tentatively correlated with the unnamed unit. At hole 8, the upper contact of the fossiliferous material is put at the contact of this material with a phosphate and quartz sand that is in sharp contact with the calcareous clayey sand beneath. Holes 1-4 did not intersect any material lithologically like 
the fossiliferous unnamed material in hole 8. It is believed that this material was not deposited on or to the west of the ridge on which hole 4 was drilled.

Bone Valley.-The lower, phosphorite unit of the Bone Valley formation was penetrated at holes $1-4$ and 8 where it is a sand or clayey sand containing abundant white phosphate nodules. The nodules are somewhat coarser than those in the underlying Hawthorn. The lower unit apparently was not deposited at the location of hole 6. The upper, clayey sand unit of the Bone Valley formation was penetrated by all holes. The unit thickens markedly to the east to the location of hole 6, then thins somewhat at hole 8. The upper contact of the clayey sand unit of the Bone Valley formation is placed at the base of the iron-stained loose sand of the Pleistocene at holes 2, 3, and 6 , and at the base of the loose sand at holes 1,4 , and 8 .

T'errace sand.-Holes 1, 2, 6 , and 8 penetrated only loose or slightly iron-stained quartz sand of probable Pleistocene age. At holes 3 and 4, however, the section is somewhat different. At these holes the section of core represented by samples 70 and 73 contained lumps and fragments of aluminum phosphate cemented sand and fragments of calcium phosphate. (See sample 73 A, p. 282.) At both holes, this material is underlain by thick sections of loose quartz sand. The material in these samples appears to be reworked; it is therefore correlated with the Pleistocene rather than the Bone Valley. At hole 4, from a depth of 14.5 to 28.6 feet, a red and white mottled clayey sand was cored. This material is lithologically unlike anything else in the cross section and is higher than the collar elevations of the other drill holes. The material is lithologically similar to material called Citronelle by Cooke (1945, p. 230). It is correlated with the Pleistocene in this cross section because of its elevation and position and because it is underlain by loose sand, and the possible reworked aluminum phosphate zone material of sample 73 .

\section{ECONOMIC GEOLOGY}

The calcium phosphate zone was penetrated by holes 1-4, and consists of phosphorites of both the Bone Valley and the Hawthorn. The phosphate nodules in cores from these holes are high in $\mathrm{P}_{2} \mathrm{O}_{5}$ content and contain more concentrate than pebble. The calcium phosphate zone is probably economic at holes 1-3; but because of its depth is probably not economic at hole 4 . Calcium phosphate nodules are present at holes 6 and 8 , but are too deep, and too low in tonnage and grade to be possibly economic; they are not considered a part of the calcium phosphate zone.

The aluminum phosphate zone was penetrated at holes 1-3 where it includes the entire upper, clayey sand unit of the Bone Valley 
formation. Cores from holes 1 and 2 were sampled, but no sample was taken of the aluminum phosphate zone at hole 3 ; the zone is delimited by the sharp radioactivity peak shown by the gamma-ray log. (See pl. 27.) Although thick clayey sands of the upper Bone Valley were penetrated at holes 4,6 and 8 , the material was not above background radioactivity as indicated by the gamma-ray logs. This material is not considered a part of the aluminum phosphate zone. At holes 3 and 4, an upper zone of possibly reworked aluminum phosphate material was penetrated, and this material was analyzed. The material represented by sample 70 contains very high phosphate and uranium in the slime fraction. It is possibly economic. The material of sample 73, while lithologically similar, is not as high grade; it is of questionable economic importance.

\section{CROSS SECTION 13}

\section{STRATIGRAPHY}

Hawthorn.-The impure limestone cores from the bottom of holes 1,2 , and 5 contained fossils identified as middle Miocene in age. The remainder of the drill holes bottomed in lithologically similar limestone, tentatively correlated with the Hawthorn. Calcareous clay at holes 1 and 2 is tentatively assigned to the Hawthorn.

Unnamed sand and limestone.-Dark-olive-gray calcareous, micaceous clayey sand and sandy clay, containing black phosphate particles, overlie limestone of the Hawthorn at holes 3-8. These dark sands are lithologically like material in hole 6 , cross section 12 , which contained fossils of late middle Miocene age. They are therefore tentatively assigned to the unnamed sand and limestone unit.

Bone Valley.-The lower, phosphorite zone of the Bone Valley was penetrated only at holes 1 and 2 ; it is apparently absent from the locations of holes $3-8$. The bottom contact of the Bone Valley at holes 1 and 2 is placed at the top of the calcareous clay of the Hawthorn. The upper, clayey sand unit of the Bone Valley is divided into a lower, fine-grained clayey sand and an upper, coarser clayey sand. The clay fraction is very minor and is white. The contact of the upper unit of the Bone Valley with the unnamed unit is placed at the top of the dark-olive micaceous phosphate-bearing sand at holes 3-8.

Terrace sand.-Loose surficial quartz sand is tentatively correlated with the Pleistocene. In addition, a red and white mottled clayey sand at holes 1 and 5, lithologically similar to the clayey sand of hole 4, cross section 12, is considered a part of the Pleistocene. (See disoussion of cross section 12 , page 257 .) 


\section{ECONOMIC GEOLOGY}

The calcium phosphate zone was penetrated by all drill holes in this line, except for hole 8. The zone includes both Hawthorn and Bone Valley at holes 1 and 2. At holes 3-7, the calcium phosphate zone is a part of the unnamed unit. The zone is probably not economic at holes 3-7 because of excessive thickness of overburden, but it is high in $\mathrm{P}_{2} \mathrm{O}_{5}$ and in tonnage. At hole 8, the zone contains too little phosphate of too low grade to be economic, thus it is not considered a part of the calcium phosphate zone at this location.

The aluminum phosphate zone, at holes 1 and 2 is a part of the Bone Valley formation; at holes 3 and 4, it is a part of the unnamed unit. The zone is not present at holes $5-8$. The zone was delimited by the high radioactivity of the gamma-ray logs at holes 1 and 2 ; at holes 3 and 4 a sample representing the high peak section of the gamma-ray log was split out from the core and analyzed.

\section{CROSS SECTION 14}

\section{STRATIGRAPHY}

Tampa.-Cores at the bottom of holes 7 and 8 contained fossils of early Miocene age. Nonfossiliferous limestone cores at the bottom of holes 3 and 4 were similar in lithology to the fossiliferous material; this limestone is tentatively correlated with the Tampa.

Hawthorn.--Limestone cored at holes 1 and 2 is impure (sandy, clayey, and containing phosphate nodules); it is lithologically similar to the Hawthorn and is hence put in that unit. Green, calcareous sandy clay, containing abundant phosphate nodules at holes 1, 2, 4, 7 , and 8 , is tentatively correlated with the Hawthorn.

Unnamed sand and limestone.-Olive-green calcareous phosphatebearing micaceous clayey sand and sandy clay at the location of holes 3-8 are lithologically similar to the material of hole 6 , cross section 15 , and are tentatively correlated with the unnamed sand and limestone unit. The material is lower in elevation than the limestone of hole 2, and forms an eastward thickening wedge of lithologically distinct material.

The upper contact of this material is placed at the base of the slightly clayey sand of the upper part of the Bone Valley, at a distinct lithologic break.

Bone Valley.-The lower, phosphorite zone of the Bone Valley is present only at hole 1. The contact of this unit with the underlying Hawthorn is placed at the top of the green calcareous clay.

The upper, clayey sand unit of the Bone Valley formation is present at all locations in this line. The unit consists of an upper, coarse- 
grained sand, with a minor amount of white clay, and a lower, fine to very fine grained sand, with a minor amount of white clay.

Terrace sand.-Loose iron-stained or cemented white quartz sand at the surface at each drill hole location is tentatively correlated with the Pleistocene. The basal contact of the terrace sand is placed at the bottom of the iron-stained sand and at the point where the sand becomes slightly clayey. At hole 8 , the bottom half of the terrace sand is the red and white mottled slightly clayey sand lithologically similar to material in cross section 12 (pl. 27). It is arbitrarily placed at the base of the Pleistocene.

\section{ECONOMIC GEOLOGY}

The calcium phosphate zone was penetrated by holes 1 and 2. At hole 1, the zone consists of phosphorite from both the Hawthorn and the Bone Valley; at hole 2, the zone is entirely within the Hawthorn. Phosphate above the limestone at hole 3 is correlated with the unnamed unit. It is not put into the calcium phosphate zone because of low $\mathrm{P}_{2} \mathrm{O}_{5}$ content (see p. 284), low tonnage, and excessive depth of overburden. Phosphate at holes 4, 7, and 8, is not put into the calcium phosphate zone because of excessive overburden thickness. The phosphorite was so deep and contained so few phosphate nodules at these holes that it was not sampled.

The aluminum phosphate zone is present only at hole 1. Analysis of sample 94 showed the slime (D) fraction to be high in phosphate and uranium and low in calcium (see p. 284). The material represented by sample 97 at hole 2 is possibly aluminum phosphate zone, but the analysis is probably too low in phosphate and uranium for the material to be economic. Gamma-ray logs indicated no abnormal radioactivity at holes 3 and 4 . At holes 7 and 8 , the high peak of the gamma-ray $\log$ is probably aluminum phosphate material, but the excessive depth of overburden makes it unlikely that this material is economic. Sample 3, hole 8, was taken of this high count material. The sample analyses indicate the material is calcium phosphate, with too low phosphate content to be economic.

\section{CROSS SECTION 15}

\section{STRATIGRAPHY}

Ocala.-Fossils from limestone cored at the bottom of hole 5 were identified as Eocene. Although no other fossiliferous limestone was cored in this line, the limestone at the bottom of the other drill holes is put in the Hawthorn on the basis of its lithologic character. If this is correct, both the Tampa and Suwannee limestones are not present, and it is possible that the location of hole 5 represents an 
upthrown fault block. Because there is no indication of faulting above the Ocala, the faulting, if present, is at least pre-Bone Valley in age.

Hawthorn.-Sandy, clayey phosphate-bearing limestone at holes 1, 2, 4, and 6 is tentatively correlated with the Hawthorn. Calcareous phosphate-bearing sandy clay above the limestone in holes 1-5 is also tentatively correlated with the Hawthorn. The contact of the Hawthorn with the overlying Bone Valley is placed at the top of the calcareous clay.

Unnamed sand and limestone.-Fossils from the bottom of a section of core of olive-gray micaceous, calcareous clayey sand, containing black phosphate nodules, were identified as middle(?) Miocene in age. This material assigned to the unnamed sand and limestone unit is lithologically distinctive and is present only at hole 8 . It is overlain by a loose sand that contains brown and black phosphate nodules and is correlated with the Bone Valley. At the bottom of drill hole 8, the unnamed unit rests on limestone correlated with the Hawthorn.

Bone Valley.-The lower, phosphorite unit of the Bone Valley formation was penetrated by all drill holes. The unit is a clayey sand that contains brown, tan, gray, and white phosphate nodules. The unit rests on calcareous clay of the Hawthorn in all drill holes except hole 8, where it rests on the unnamed olive micaceous clayey sand.

The upper, clayey sand unit of the Bone Valley consists of a medium to coarse-grained slightly clayey sand. The clay fraction is white.

Terrace sand.-Loose white to slightly iron-stained sand at the surface at each drill hole location is correlated with the Pleistocene. In addition, a mottled red and white slightly clayey sand was penetrated at holes $3-5$. This material is lithologically distinct and similar to the material in cross section 12. At hole 3 , it is high in the section, at holes 4 and 5, it forms the basal part of the Pleistocene. The base of the Pleistocene at hole 2 is put at the base of the sand with some phosphate particles. The phosphate in this section of core consists of fine-grained, angular fragments. It appears to be broken particles of phosphate nodules and is thought to be reworked.

\section{ECONOMIC GEOLOGY}

The calcium phosphate zone was penetrated by all drill holes except for hole 6. The zone is entirely within the Bone Valley at holes 1-4, but consists of both Hawthorn and Bone Valley at hole 5. At hole 6, the phosphate is deep, low in $\mathrm{P}_{2} \mathrm{O}_{5}$ content, and low in tonnage; this material is not included in the calcium phosphate zone. The phosphate at holes 3 and 4 is covered by a thick section of barren material (overburden) and is probably not economic for that reason. 
The aluminum phosphate zone is present at holes 1-4. At these holes the top contact of the aluminum phosphate zone is taken at the mid-point of the sharp rise in radioactivity as shown by the gammaray logs (pl. 30). The zone is uniformly thin, and is covered by thick barren quartz sand; it is probably not economic in this section.

\section{CROSS SECTION 16}

\section{STRATIGRAPHY}

Ocala.-Fossils from limestone at the bottom of holes 1 and 1a were identified as Eocene in age. As mentioned in the discussion of cross section 15, the Ocala limestone here may be in an upthrown fault block.

Hawthorn.-Limestone cored at the bottom of holes 1 and 3 are assigned to the Hawthorn on the basis of lithologic character. In addition, calcareous sandy phosphate-bearing clay above the limestone at all holes except 4, is tentatively correlated with the Hawthorn. At hole 4 a thick section of green silty and sandy clay, phosphate bearing at the bottom and about the middle of the section, is tentatively correlated with the Hawthorn. This material may be equivalent to the Alachua (?) and may represent a channel or sink-hole filling of reworked Hawthorn. The material is somewhat similar to the Hawthorn, but is also similar to material in cross section 17 that is called Alachua (?).

Bone Valley.-The lower, phosphate unit of the Bone Valley formation is apparently not present in this section. The upper unit is divided into a lower stratum of slightly clayey fine-grained sand and an upper stratum of clayey coarse-grained sand. The clay fraction of the upper Bone Valley is white.

Terrace sand.-Loose quartz sand, stained with iron and containing organic material at holes $1 \mathrm{a}$ and 2 , is correlated with the Pleistocene. At hole 1, the middle part of the terrace sand consists of red and white mottled slightly clayey sand, and at hole 4, the bottom half of the terrace sand is composed of this material. The red and white mottled material is lithologically distinctive; it is arbitrarily placed in the Pleistocene. (See discussion of cross section 12.)

\section{ECONOMIC GEOLOGY}

The calcium phosphate zone was penetrated at holes 1a, 2, and 5, and is entirely within the Hawthorn formation. It is absent at the location of the remainder of the holes in this line.

The aluminum phosphate zone is present at holes $1,1 \mathrm{a}, 2 ; 3$, and 5 . The zone is very thin, and questionably economic. Except at hole 5, where it is within the Hawthorn, the zone is the basal part of the Bone Valley. 


\section{CROSS SECTION 17}

\section{STRATIGRAPHY}

Suwannee.-Fossils from limestone at the bottom of holes 5, 6, and 9-11 were identified as Oligocene in age and the limestone is assigned to the Suwannee. Lithologically similar limestone cored at holes 3, 7 , and 8 is tentatively correlated with the Suwannee.

Tampa.-Green sandy calcareous clay, containing chert fragments and nodules, contain fossils identified as early Miocene at holes 4 and 9. Lithologically similar clay at holes $3,5-8$, and 10 are tentatively correlated with the Tampa. Impure limestone cored at hole 2 is tentatively correlated with the Tampa. At hole 3, the Tampa is overlain by calcareous phosphatic sandy clay of the Hawthorn. At holes 4-7 the Tampa is overlain by slightly clayey sand of the upper part of the Bone Valley, and at holes 8-10 the Tampa is overlain by sandy clay of the Alachua (?).

Hawthorn.-Calcareous sandy phosphate-bearing clay at holes 1-3 is tentatively correlated with the Hawthorn. At holes 1 and 2, the calcareous clay is overlain by green clay or sandy clay, also assigned to the Hawthorn. The Hawthorn is overlain at holes 1 and 2 by white clayey sand of the upper part of the Bone Valley, and at hole 3, by phosphorite of the lower Bone Valley. The Hawthorn is absent at holes 4-11, although the material assigned to the Alachua (?) at holes 8-11 may be a residuum of the Hawthorn.

Alachua (?).-Coarse- to medium-grained sandy clay, green to blue to shades of red and yellow and containing fragments of angular white phosphate, were penetrated at holes $8-11$. This material is lithologically distinct. The material overlies clastic rock assigned to the Tampa at holes 8-10, and limestone of Oligocene age at hole 11. It is overlain by clayey sand of the upper Bone Valley at holes 8, 9, and 11, and by phosphorite of the lower part of the Bone Valley at hole 10. From its position in the section, and distinctive lithology, this material is tentatively correlated with the Alachua(?) fornation, although it is possible that the material is equivalent to the lower part of the Bone Valley.

Bone Valley.-The lower, phosphorite unit of the Bone Valley was intersected only at holes 3 and possibly 10 . The unit is absent in the remaining drill holes. At hole 3, the lower unit overlies calcareous clay of the Hawthorn; at hole 10 the material overlies sandy clay of the Alachua (?) formation. In both cases the contact is distinct.

The upper, clayey sand unit of the Bone Valley formation was intersected at all drill holes. The unit is distinctive lithologically, consisting of medium- to fine-grained sand and minor amounts of white clay. 
The unit apparently contains aluminum phosphate minerals, as indicated by the rise in the gamma-ray logs, at most drill-hole locations.

Terrace sand.-A thin blanket of loose quartz sand, stained with iron at some locations, was penetrated at each drill-hole location. The loose sand thickens at hole 10, at the ridge, and the thickening may be due to the increased elevation at this locality.

\section{FCONOMIC GEOLOGY}

The calcium phosphate zone was penetrated at holes 1-3 and10; it is absent at the remaining locations. At holes 1 and 2, the zone is entirely within the Hawthorn formation, while at holes 3 and 10, it is entirely within the Bone Valley formation. Analyses of the samples from holes 2,3 , and 10 indicate the zone is probably economic.

The aluminum phosphate zone was penetrated at all drill holes. The zone is delimited by the high peak of radioactivity as indicated by the gamma-ray logs. The zone was not sampled in this cross section. Cross section 17 is an excellent example of the nature of the aluminum phosphate zone, and the way the zone crosses stratigraphic lines. At holes 4, 5, 7, 10, and 11, the entire upper unit of the Bone Valley formation is aluminum phosphate zone. At holes 3, 8, and 9, only the basal part of the upper Bone Valley is aluminum phosphate zone. At holes 1 and 2 the basal part of the upper Bone Valley plus the top part of the Hawthorn make up the aluminum phosphate zone, and at hole 6, the aluminum phosphate zone is within the Tampa formation. Although the zone varies in radiation intensity, it is marked in every drill hole by a peak of radiation intensity. (See pl. 32.)

\section{CROSS SECTION 18}

\section{STRATIGRAPHY}

Hawthorn.-Limestone cored at the bottom of hole 1 is impure, sandy, clayey, and phosphate bearing; it is correlated with the Hawthorn. Calcareous clay overlying the limestone at hole 1 is also lithologically similar to the Hawthorn and is similarly assigned. Green slightly sandy clay at the bottom of hole 4 is tentatively correlated with the Hawthorn. The contact of the Hawthorn with the Bone Valley at hole 1 is placed at the top of the calcareous, phosphatic clay. At hole 2, the Hawthorn-Bone Valley contact is placed at the base of the white slightly clayey sand of the upper part of the Bone Valley.

Bone Valley.-The lower, phosphorite of the Bone Valley was penetrated at hole 1. The upper, slightly clayey sand of the Bone Valley was penetrated at holes 1 and 4. At hole 4, the upper, clayey sand of the Bone Valley rests directly on green sandy clay of the Hawthorn.

Terrace sand.-Loose slightly iron-stained quartz sand that contains 
organic material is correlated with the Pleistocene. The sand is present at both locations in this cross section.

\section{ECONOMIC GEOLOGY}

The calcium phosphate zone was intersected only at hole 1 , where it consists of the lower, phosphorite unit of the Bone Valley plus the top of the calcareous clay of the Hawthorn. No phosphorite is present at hole 4 .

The aluminum phosphate zone was intersected by both drill holes of cross section 18. At hole 1, the zone is the lower part of the clayey sand of the upper part of the Bone Valley, while at hole 4 the aluminum phosphate zone is entirely within the Hawthorn. The zone was not sampled and was delimited entirely by use of the gamma-ray logs.

\section{TONNAGE CALCULATIONS}

\section{ALUMINOM PHOSPHATE ZONE}

Tonnages were calculated by a modification of the method used in the district for calculating the matrix tonnages. The method is based on the thickness of the deposit and the weight per cubic foot of rock in place.

A bed one foot thick contains 1,613 cubic yards per acre.

43,560 (square feet per acre) $\times 1$ (thickness in feet) $=43,560$ cubic feet per acre-foot.

$\frac{43,560 \text { (cubic feet per acre-foot) }}{27 \text { (cubic feet per cubic yard) }}=1613.33$ cubic yards per acre-foot, and, rounding, $1,600 \times$ thickness $($ in feet) $=$ cubic yards per acre.

Cubic yards per acre is shown on all of the tables because the weight per cubic foot of aluminum phosphate zone material varies between wide limits. This figure may be changed to tons per acre by using a factor of 90 pounds per cubic foot, the approximate average weight of a cubic foot of aluminum phosphate zone material. This is equivalent to 2,430 pounds per cubic yard; 1.088 long tons per cubic yard, or 1.215 short tons per cubic yard.

\section{CALCIUM PHOSPHATE ZONE (MATRIX)}

The tonnage calculations used in this report are based on the thickness of the phosphate bed, its percentage of contained pebble or concentrate, and the specific gravity of the deposit. The phosphate companies use the weight of a cubic foot of matrix instead of the specific 
gravity. For much of the area, this weight is about 125 pounds. Thus, the tonnage calculations are as follows:

$\frac{\text { Square feet per acre }(43,560) \times 125}{\text { long ton }(2240 \text { pounds })}=2430.8$,

or $2430=$ constant. $2430 \times$ thickness (feet) $\times$ percentage of pebble (or concentrate) $=$ tons of pebble (or concentrate) per acre.

No correction was made for the variation in weight per cubic foot. However, this variation is small; computation shows that a change of 1 pound in weight of a cubic foot of matrix changes the total tonnage $1 / 5$ ton per foot of matrix for 1 percent of pebble, or concentrate.

Long tons are used in this report to conform with general practice in the phosphate field. Long tons can be converted to short tons (2000 pounds) by multiplying the given tonnage figure by 1.12 .

$$
\frac{2240}{2000}=1.12
$$

Grade is shown in percent BPL (bone phosphate of lime) the conversion factor is:

$$
\mathrm{P}_{2} \mathrm{O}_{5} \text { percent } \times 2.185=\mathrm{BPL} \text { percent. }
$$

Tonnage data for both the aluminum phosphate and calcium phosphate zones are given on pages $287-295$.

\section{REFERENCES CITED}

Altschuler, Z. S., and Cisney, E. A., 1952, X-ray evidence of the nature of carbonate apatite [abs.]: Geol. Soc. America Bull., v. 63, no. 12, pt. 2.

Bergendahl, M. H., 1956, Stratigraphy of parts of DeSoto and Hardee Counties, Florida : U. S. Geol. Survey Bull. 1030-13.

Berman, Robert, 1953, A mineralogic study of churn drill cuttings from a well through the Bone Valley formation, Hillsborough County, Florida [abs.]: Nuclear Science Abstracts, $\nabla .7$, no. $18 \mathrm{~A}$.

Brodkorb, Pierce, 1955, The avifauna of the Bone Valley formation: Florida Geol. Survey Rept. Inv. 14.

Carr, W. J., and Alverson, D. C., 1953, Stratigraphy of Suwannee, Tampa, and Hawthorn formations in Hillsborough and parts of adjacent counties, Fla., in Geologic investigations of Radioactive deposits-Seniannual progress report, June 1 to Nov. 30, 1953: U. S. Geol. Survey TEI-390, U. S. Atomic Energy Comm., Tech. Inf. Service, Oak Ridge.

Cooke, C. W., 1915, The age of the Ocala limestone: U. S. Geol. Survey Prof. Paper 95.

19+5, Geology of Florida : Florida Geol. Survey Bull. 29.

Cooke, C. W., and Mansfield, W. C., 1936, Suwannee limestone of Florida [abs.] : Geol. Soc. America. Proc. 1935.

Cooke, C. W., and Mossom, D. S., 1929, Geology of Florida: Florida Geol. Survey 20th Ann. Rept. 
Dall, W. H., and Harris, G. D., 1892, Correlation papers-Neocene : U. S. Geol. Survey Bull. 84.

Fowler, E. D., and others, 1927, Soil Survey of Polk County, Florida: U. S. Dept. Agriculture Soil Survey Rept. 39.

Johnson, L. C., 1888, The structure of Florida: Am. Jour. Sci., ser. 3, v. 36.

King, P. B., 1951, The tectonics of middle North America-Middle North America east of the Cordilleran System: Princeton, N. J., Princeton Univ. Press. $203 \mathrm{p}$.

MacNeil, F. S., 1947, Correlation chart for the outcropping Tertiary formations of the eastern Gulf Coastal Plain: U. S. Geol. Survey Oil and Gas Inv. Prelim. Chart 29.

Mansfield, W. C., 1937, Mollusks of the Tampa and Suwannee limestones of Florida : Florida Geol. Survey Bull. 15.

Matson, G. C., and Clapp, F. G., 1909, A preliminary report on the geology of Florida with special reference to the stratigraphy: Florida Geol. Survey 2d Ann. Rept.

Mossom, D. S., 1925, A preliminary report on the limestones and marls of Florida : Florida Geol. Survey 16th Ann. Rept.

Palache, Charles, Berman, Harry, and Frondel, Clifford, 1951, Dana's system of mineralogy, V. 2: 7th ed., revised, New York, John Wiley and Sons, Inc.

Simpson, G. G., 1929, The extinct land mammals of Florida: Florida Geol. Survey 20th Ann. Rept.

- 1930, Tertiary land mammals of Florida : Am. Mus. Nat. History Bull., v. 59, art. 11.

Vernon, R. O., 1951, Geology of Citrus and Levy Countles, Florida: Florida Geol. Survey Bull. 33. 
BASIC DATA 



\section{ANALYTICAL AND SCREEN DATA FOR CROSS SECTIONS 1-18}

[Screen size: A, +14 mesh; B, -14 +35 mesh; C, $-35+150$ mesh; D, -150 mesh; E, $-35+150$ concentrate; $\mathrm{F},-35+150$ tailings]

\begin{tabular}{c|c|c|c|c|c|c|c|c|c|}
\hline $\begin{array}{c}\text { Hole and } \\
\text { sample }\end{array}$ & $\begin{array}{c}\text { Sample } \\
\text { interval } \\
\text { (feet) }\end{array}$ & $\begin{array}{c}\text { Sereen } \\
\text { size }\end{array}$ & $\begin{array}{c}\text { Weight } \\
\text { (nercent } \\
\text { retained } \\
\text { on } \\
\text { screen) }\end{array}$ & $\mathrm{P}_{2} \mathrm{O}_{3}$ & $\mathrm{CaO}$ & $\mathrm{F}$ & $\mathrm{Al}_{2} \mathrm{O}_{2}$ & $\mathrm{U}$ & $\mathrm{eU}$ \\
\hline
\end{tabular}

Cross gection 1

[A] samples are from lot 2545. Chemical analyses by E. Campbell, L. Jenkins, I. H. Barlow, R. Smith, J. Smith, W. P. Tucker, J. Budinsky. Radiometric (eU) analyses by B. A. McCall, J. H. Goode, Jr.]

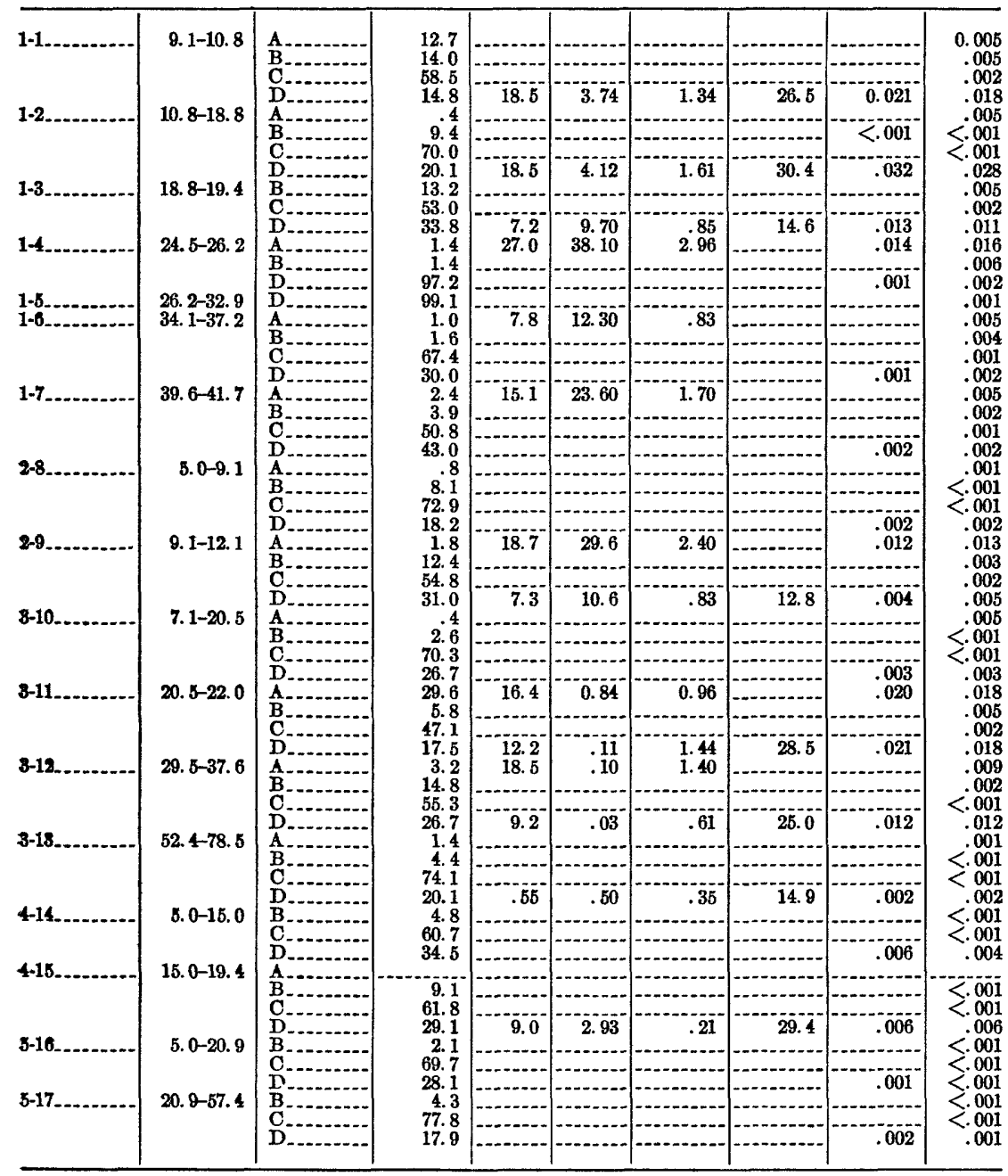




\begin{tabular}{l|c|c|c|c|c|c|c|c|c}
\hline $\begin{array}{c}\text { Hole and } \\
\text { sample }\end{array}$ & $\begin{array}{c}\text { Sample } \\
\text { interval } \\
\text { (feet) }\end{array}$ & $\begin{array}{c}\text { Screen } \\
\text { size }\end{array}$ & $\begin{array}{c}\text { Weight } \\
\text { (percent } \\
\text { retained } \\
\text { on } \\
\text { screen) }\end{array}$ & \multicolumn{5}{|c|}{ Analytical data (percent) } \\
\cline { 3 - 6 }
\end{tabular}

Cross section 2

[All samples are from lot 2545. Chemical analyses by E. Campbell, L. Jenkins, I. H. Barlow, R. Smith J. Smith, W. P. Tucker, J. Budinsky. Radiometric (eU) analyses by B. A. McCall, J. H. Goode, Jr.]

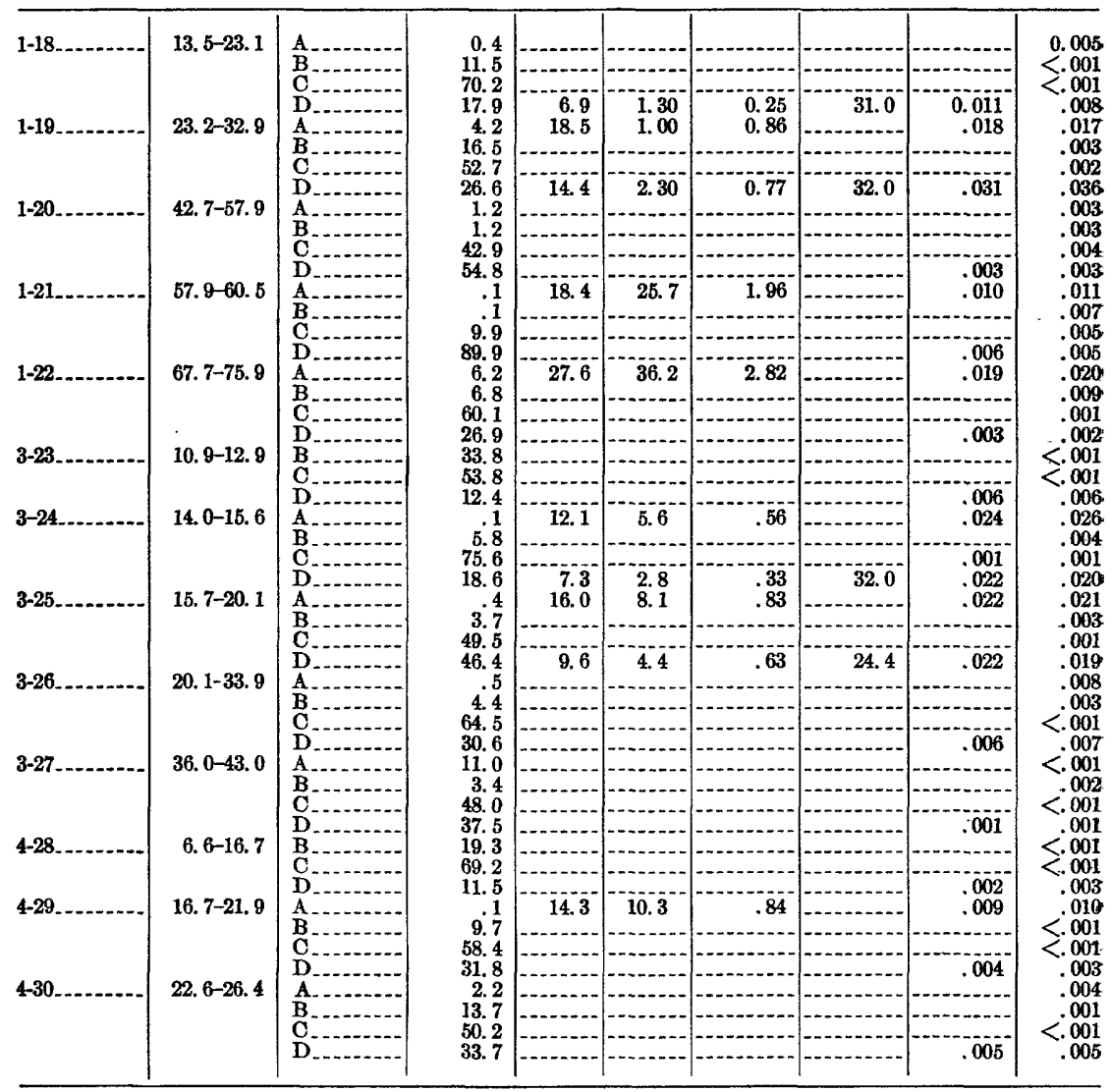

Crass section 3

[All samples are from lot 2545. Chemical analyses by S. Bethea, E. Campbell, L. Jenkms, I. H. Barlow, R. Smith, J. Smith, W. P. Tucker, J. Budinsky. Radiometric (eU) analyses by B. A. McCall, J. H. Goode, Jr.]

\begin{tabular}{|c|c|c|c|c|c|c|c|c|c|}
\hline \multirow[t]{2}{*}{$1-31 \ldots \ldots$} & 14. 9-16. 1 & A & $\begin{array}{l}19.2 \\
17.1\end{array}$ & $\begin{array}{l}36.1 \\
31.2\end{array}$ & $\begin{array}{l}49.6 \\
42.3\end{array}$ & $\begin{array}{l}4.07 \\
3.36\end{array}$ & $\cdots$ & $\begin{array}{r}0.010 \\
.010\end{array}$ & $\begin{array}{r}0.012 \\
.010\end{array}$ \\
\hline & & $\begin{array}{l}\mathrm{D} \\
\mathbf{E} \\
\mathbf{F}\end{array}$ & $\begin{array}{r}43.0 \\
7.9 \\
12.9\end{array}$ & $\begin{array}{l}18.5 \\
36.5\end{array}$ & $\begin{array}{l}27.8 \\
49.0\end{array}$ & $\begin{array}{l}2.07 \\
3.85\end{array}$ & $\begin{array}{r}12.4 \\
\end{array}$ & $\begin{array}{l}.005 \\
.012\end{array}$ & $\begin{array}{l}.006 \\
.013 \\
.004\end{array}$ \\
\hline $1-32 \ldots$ & $28.4-43.5$ & & $\begin{array}{r}3.2 \\
16.3\end{array}$ & 30.9 & 42.6 & 3.43 & & & $\begin{array}{l}.006 \\
.001\end{array}$ \\
\hline $1-33 \ldots$ & $43.6-59.9$ & $\begin{array}{l}\mathrm{O} \\
\mathrm{D} \\
\mathrm{A} \\
\mathrm{B} \\
\mathrm{C} \\
\mathrm{D}\end{array}$ & $\begin{array}{r}44.5 \\
36.0 \\
.9 \\
2.4 \\
40.2 \\
56.5\end{array}$ & $\cdots$ & . & $\cdots$ & $\cdots$ & $\begin{array}{c}.001 \\
.001 \\
0\end{array}$ & $\begin{array}{l}.001 \\
.002 \\
.002 \\
.002 \\
.001 \\
.002\end{array}$ \\
\hline
\end{tabular}


CORE DRILLING, LAND-PEBBLE PHOSPHATE DISTRICT, FLORIDA 273

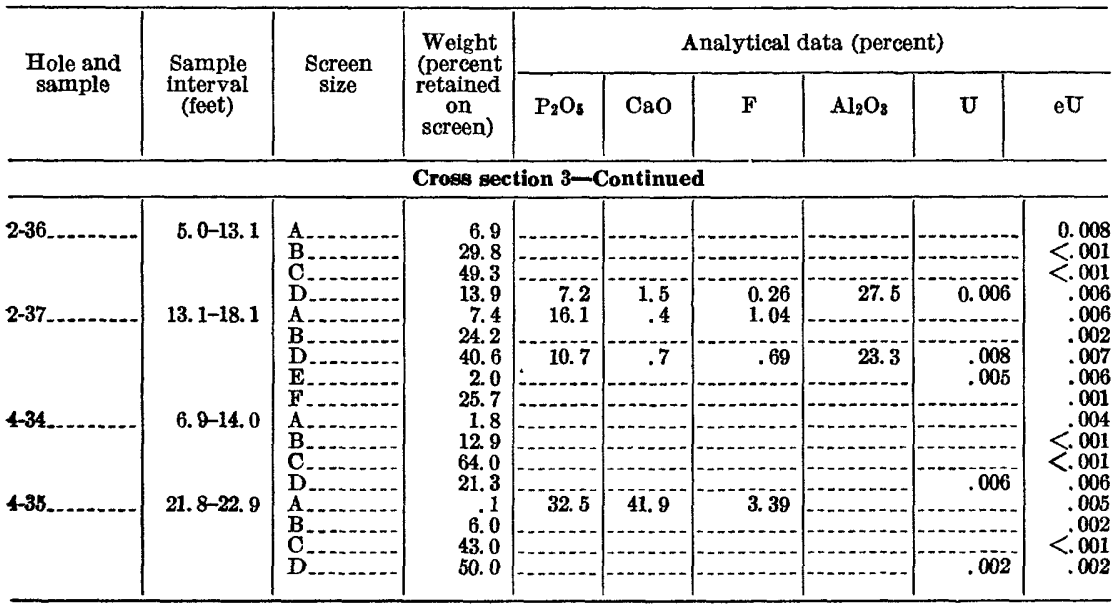

\section{Cross section 4}

[All samples are from lot 2545. Chemical analyses by S. Bethea, E. Campoell, L. Jenkins, I. H. Barlow, R. Smith, J. Smith, W. P. Tucker, J. Budinsky. Radiometric (eU) analyses by B. A. McCall, J. H. Goode, Jr.]

\begin{tabular}{|c|c|c|c|c|c|c|c|c|c|}
\hline $1-40$ & $19.2-35.8$ & A & 2.9 & 35.1 & 46.2 & 3. 79 & $\cdots$ & & 0.013 \\
\hline & & & $\begin{array}{r}8.1 \\
60.3\end{array}$ & $\cdots$ & 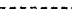 & $-\infty$ & & & .004 \\
\hline $1-11 \ldots \ldots$ & $35.9-39.9$ & A & $\begin{array}{r}28.6 \\
2.1\end{array}$ & 30.7 & 41.9 & 3.29 & & $\begin{array}{r}0.007 \\
0\end{array}$ & $\begin{array}{l}.005 \\
.006\end{array}$ \\
\hline & & C. & $\begin{array}{r}3.6 \\
59.3\end{array}$ & & & & $\cdots$ & $-\cdots$ & .003 \\
\hline $2-38$ & $17.6-24.5$ & $\mathbf{D}$ & $\begin{array}{r}35.0 \\
1.6\end{array}$ & 29.1 & 44.9 & 3.50 & $\ldots$ & .003 & $\begin{array}{l}.002 \\
.012\end{array}$ \\
\hline & & B.- & $\begin{array}{r}4.7 \\
47.0\end{array}$ & $\cdots+\cdots$ & -.......... & $\cdots$ & & & .004 \\
\hline & & & 46.8 & & & & & .002 & .002 \\
\hline $3-39$ & $28.6-45.4$ & A. & 3.7 & 30.2 & 45. 2 & 3. 21 & & $\cdots$ & $<.001$ \\
\hline & & & $\begin{array}{r}8.0 \\
51.1\end{array}$ & $\cdots$ & ......... & $\cdots$ & $\cdots$ & $\cdots$ & $\begin{array}{l}.002 \\
.001\end{array}$ \\
\hline & & & 37.2 & & & & - & .001 & $<.001$ \\
\hline
\end{tabular}

Cross section 5

[All samples are from lot 2545. Chemical analyses by S. Bethea, E. Campbell, L. Jenkins, I. H. Barlow R. Smith, J. Smith, W. P. Tucker, J. Budinsky. Radiometric (eU) analyses by B. A. McCall, J. H. Goode, Jr.]

\begin{tabular}{|c|c|c|c|c|c|c|c|c|c|}
\hline \multirow{2}{*}{$1-42 \ldots$} & 49. 2-56. 1 & A & 0.4 & 5.7 & 3. 5 & 0.2 & & & 0.006 \\
\hline & & & 50.3 & . & 0 & 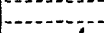 & & 0019 & $\therefore 0$ \\
\hline \multirow[t]{3}{*}{$1-43}$. & $56.1-71.9$ & & $\begin{array}{l}5.2 \\
7.7\end{array}$ & 10.3 & 6.2 & .4 & 21.2 & 0.012 & $<.001$ \\
\hline & & & 17.9 & $\ldots$ & .. &.- & . & & .004 \\
\hline & & D. & 14.0 & $\cdots$ & & & & $.004^{-}$ & .002 \\
\hline $2-44$ & $28.1-34.6$ & A & $\begin{array}{r}2.7 \\
14.3\end{array}$ & - & $\ldots$ & $\ldots$ & - & $-\ldots$ & $\begin{array}{l}.014 \\
.008\end{array}$ \\
\hline \multirow[t]{3}{*}{$2-45 \ldots \ldots \ldots$} & $34.6-48.9$ & & $\begin{array}{r}50.1 \\
27.9 \\
2.1\end{array}$ & $\begin{array}{r}5.1 \\
18.6\end{array}$ & $\begin{array}{r}8.9 \\
39.5\end{array}$ & $\begin{array}{r}.8 \\
2.6\end{array}$ & 16.2 & .005 & $\begin{array}{l}.004 \\
.004 \\
.008\end{array}$ \\
\hline & & & $\begin{array}{r}7.5 \\
52.3\end{array}$ & & & & $-\cdots$ & .001 & $<.001$ \\
\hline & $22.5-32.8$ & & $\begin{array}{r}6.8 \\
31.3 \\
2.7\end{array}$ & $\begin{array}{l}30.4 \\
16.4\end{array}$ & $\begin{array}{l}43.4 \\
24.7\end{array}$ & $\begin{array}{l}3.5 \\
1.9\end{array}$ & & & .009 \\
\hline \multirow{2}{*}{$3-46 \ldots$} & & & $\begin{array}{l}15.2 \\
38.4\end{array}$ & & & & & .003 & .006 \\
\hline & & $\mathbf{E}$ & 15.0 & 30.6 & 45.0 & 3.6 & & ..... & .008 \\
\hline \multirow[t]{2}{*}{$4-47 \ldots \ldots$} & $21.4-26.2$ & A & $\begin{array}{r}20.5 \\
9.1\end{array}$ & $\begin{array}{l}23.7 \\
24.4\end{array}$ & $\begin{array}{l}39.9 \\
37.7\end{array}$ & $\begin{array}{l}2.8 \\
2.9\end{array}$ & $\cdots$ & .017 & $\begin{array}{l}.000 \\
.015 \\
.015\end{array}$ \\
\hline & & $\begin{array}{l}\mathrm{D} \\
\mathrm{D} \\
\mathrm{E} \\
\mathrm{F}\end{array}$ & $\begin{array}{r}55.5 \\
5.3 \\
17.6\end{array}$ & $\begin{array}{r}8.2 \\
30.8\end{array}$ & $\begin{array}{l}24.6 \\
45.2\end{array}$ & $\begin{array}{l}1.2 \\
3.6\end{array}$ & 3.7 & .011 & $\begin{array}{l}.004 \\
.016 \\
.006\end{array}$ \\
\hline
\end{tabular}




\begin{tabular}{|c|c|c|c|c|c|c|c|c|c|}
\hline \multirow{2}{*}{$\begin{array}{l}\text { Hole and } \\
\text { sample }\end{array}$} & \multirow{2}{*}{$\begin{array}{c}\text { Sample } \\
\text { interval } \\
\text { (feet) }\end{array}$} & \multirow{2}{*}{$\begin{array}{c}\text { Screen } \\
\text { size }\end{array}$} & \multirow{2}{*}{$\begin{array}{l}\text { Weight } \\
\text { (porcent } \\
\text { retained } \\
\text { on } \\
\text { screen) }\end{array}$} & \multicolumn{6}{|c|}{ Analytical data (percent) } \\
\hline & & & & $\mathrm{P}_{2} \mathrm{O}_{5}$ & $\mathrm{CaO}$ & $\mathbf{F}$ & $\mathrm{Al}_{2} \mathrm{O}_{3}$ & U & eU \\
\hline
\end{tabular}

Cross section 6

[All samples are from lot 2545. Chemical analyses by R. Moore, J. Smith, W. P. Tucker, J. Budinsky, L. Jenkins, E. Campbell, I. H. Barlow, R. Smith. Radiometric (eU) analyses by J. H. Goode, Jr., B. A. McCall]

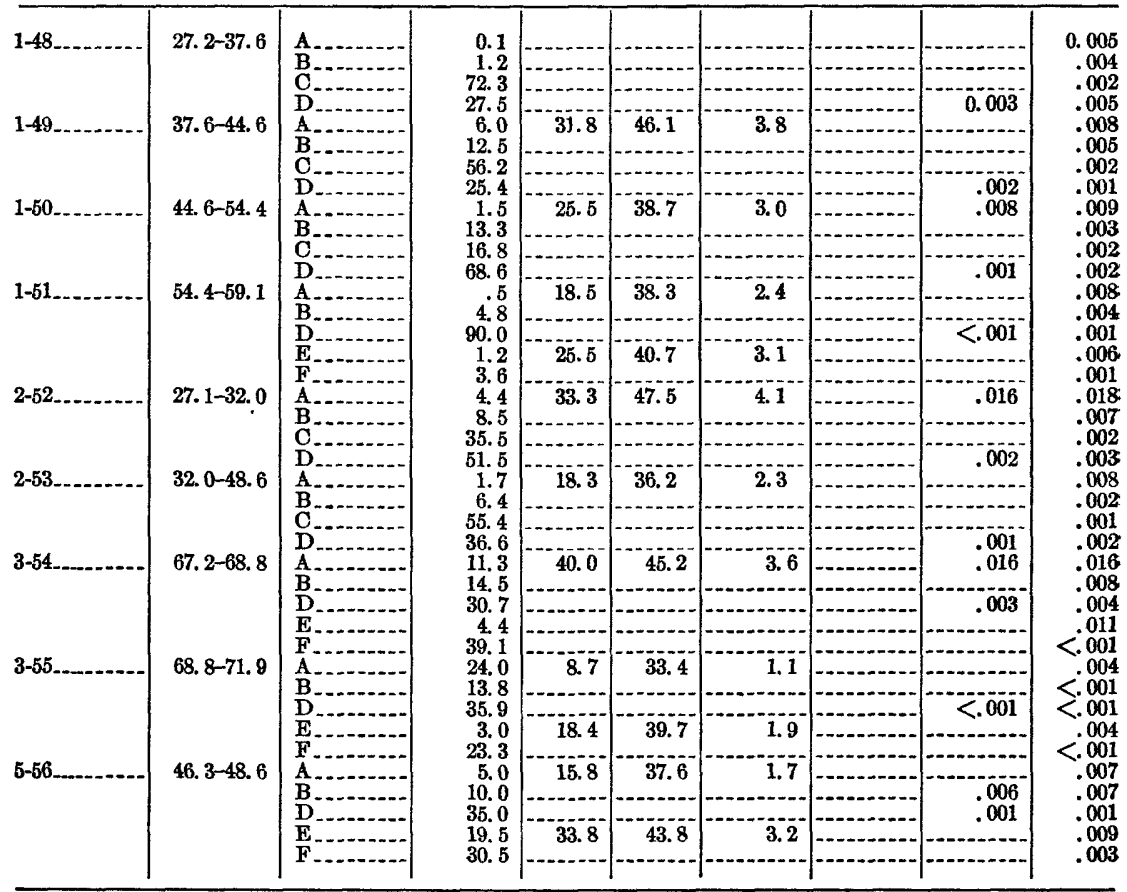

Crass section 7

[All samples are from lot 2545. Chemical analyses by R. Moore, J. Smith, W. P. Tucker, J. Budinsky, L. Jenkins, E. Campbell, I. H. Barlow, R. Smith. Radiometric (eU) analyses by J. H. Goode, Jr., B. A. McCall]

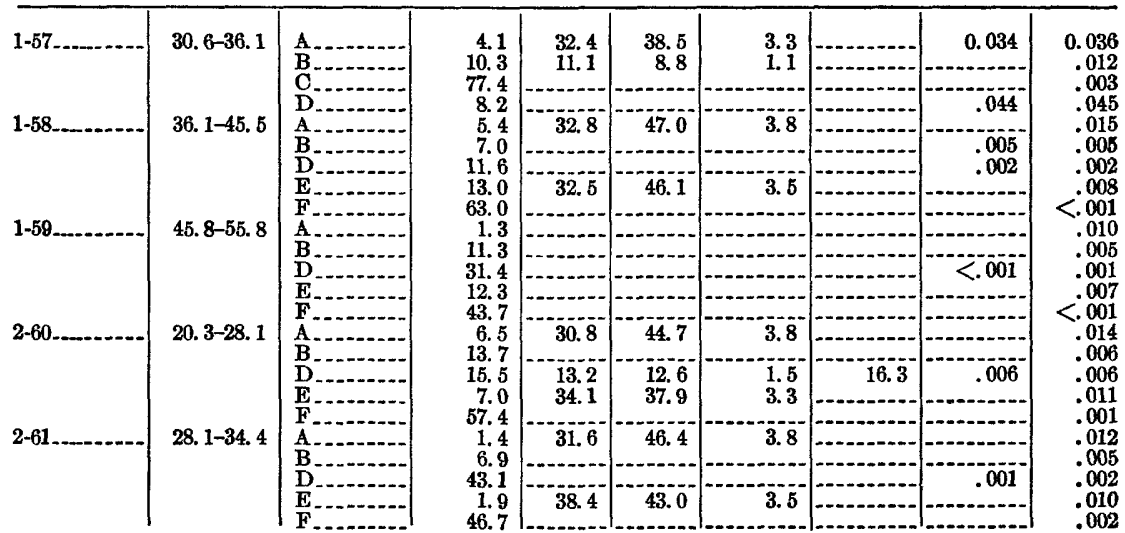


CORE DRILLING, LAND-PEBBLE PHOSPHATE DISTRICT, FLORIDA 275

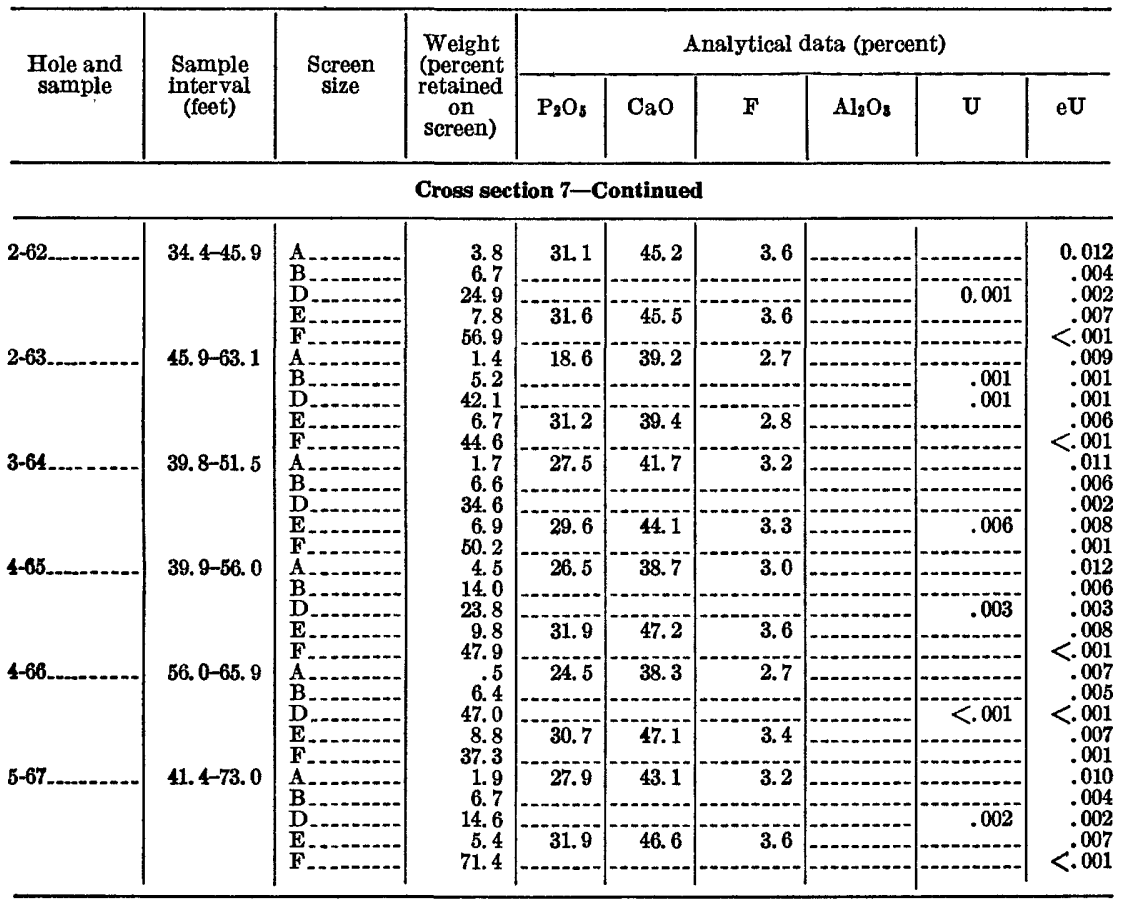

\section{Cross section 8}

[All samples are from lot 2545. Chemical analyses by R. Moore, J. Smith, W. P. Tucker, J. Budinsky, L. Jenkins, E. Campbell, I. H. Barlow, R. Smith. Radiometric (eU) analyses by J. H. Goode, Jr., B. A. McCall]

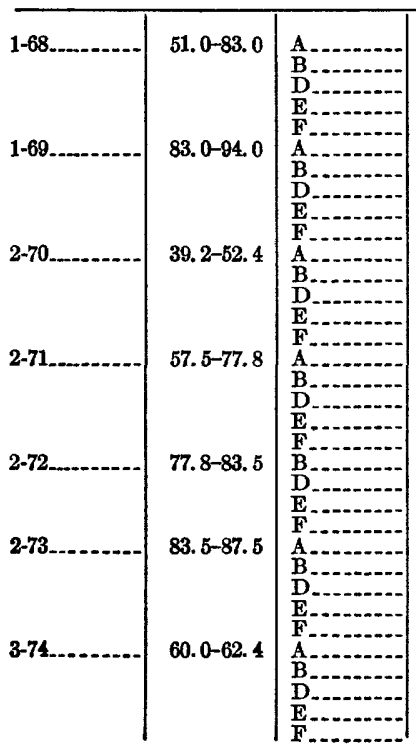

\begin{tabular}{|c|c|c|c|c|c|}
\hline .4 & 16.8 & 37.5 & 1.9 & & \\
\hline 2.7 & & -....... & & & \\
\hline $\begin{array}{l}11.9 \\
11.7\end{array}$ & 31.9 & 46.2 & 3.7 & & \\
\hline $\begin{array}{l}3.3 \\
1.3\end{array}$ & & & & & \\
\hline $\begin{array}{l}1.3 \\
7.1\end{array}$ & 18.4 & 38.1 & 2.2 & & \\
\hline 45.0 & & & & & \\
\hline $\begin{array}{r}6.1 \\
40.5\end{array}$ & 27.1 & 40.1 & 2.8 & & \\
\hline 9.0 & 18.6 & 30.6 & 2.3 & & \\
\hline 20.0 & & - & & & 3 \\
\hline 4.0 & 31.5 & 44.0 & 3.5 & & \\
\hline 3. 0 & 13.5 & 22.3 & 1.5 & & \\
\hline $\begin{array}{r}3.0 \\
29.0\end{array}$ & & 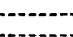 & & & 002 \\
\hline 6.0 & 28.5 & 42.3 & 3.4 & & \\
\hline $\begin{array}{r}59.0 \\
1.8\end{array}$ & - & 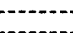 & $D_{-1}$ & & \\
\hline 58.9 & & & & & \\
\hline 2. 5 & 28.7 & 42.5 & 3.1 & & \\
\hline 8.5 & 13.3 & 30.7 & 1.5 & & \\
\hline $\begin{array}{r}18.0 \\
6.5\end{array}$ & 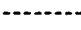 & - & $=-$ & & \\
\hline 6. 2 & 28.9 & 45.4 & 3.2 & & 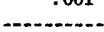 \\
\hline $\begin{array}{l}00.8 \\
51.0\end{array}$ & 13.8 & 32.8 & 1.6 & & \\
\hline $\begin{array}{l}2.0 \\
2.0\end{array}$ & $\cdots$ & & & & \\
\hline $\begin{array}{r}3.7 \\
41.3\end{array}$ & 26.8 & 42.1 & 3.2 & & \\
\hline
\end{tabular}




\begin{tabular}{|c|c|c|c|c|c|c|c|c|c|}
\hline \multirow{2}{*}{$\begin{array}{c}\text { Hole and } \\
\text { sample }\end{array}$} & \multirow{2}{*}{$\begin{array}{c}\text { Sample } \\
\text { interval } \\
\text { (feet) }\end{array}$} & \multirow{2}{*}{$\begin{array}{l}\text { Screen } \\
\text { size }\end{array}$} & \multirow{2}{*}{$\begin{array}{c}\text { Weight } \\
\text { (percent } \\
\text { retained } \\
\text { on } \\
\text { screen) }\end{array}$} & \multicolumn{6}{|c|}{ Analytical data (percent) } \\
\hline & & & & $\mathrm{P}_{2} \mathrm{O}_{5}$ & $\mathrm{CaO}$ & $\mathbf{F}$ & $\mathrm{Al}_{2} \mathrm{O}_{3}$ & $\mathbf{U}$ & $\mathrm{eU}$ \\
\hline \multicolumn{10}{|c|}{ Cross section 8-Continued } \\
\hline \multirow[t]{2}{*}{ 4-75 } & \multirow[t]{2}{*}{$45.5-50.3$} & & 14. 8 & 25.6 & 36. 2 & 2.9 & & 0.013 & \multirow{4}{*}{$\begin{array}{r}0.014 \\
.005 \\
.009 \\
.010 \\
.001 \\
.012 \\
.005 \\
.002 \\
.010 \\
.001\end{array}$} \\
\hline & & & $\begin{array}{r}14.4 \\
5.2\end{array}$ & $\begin{array}{r}7.4 \\
30.0\end{array}$ & $\begin{array}{l}11.0 \\
43.4\end{array}$ & $\begin{array}{r}.9 \\
3.4\end{array}$ & 12.1 & .007 & \\
\hline \multirow[t]{2}{*}{$4-76$} & \multirow[t]{2}{*}{$56.1-63.4$} & A-- & 8.6 & 22.9 & 40.2 & 2.7 & - n & (n) & \\
\hline & & & $\begin{array}{r}15.2 \\
7.9 \\
61.6\end{array}$ & 30.0 & 45.1 & 3.4 & $\cdots$ & $\begin{array}{l}.001 \\
.009\end{array}$ & \\
\hline & & & & & & & & & \\
\hline
\end{tabular}

\section{Cross section 9}

[Samples 78-100 are from lot 2545; samples 1 and 2 are from lot 2546. Chemical analyses by G. J. Daniels, R. Moore, J. Smith, W. P. Tucker, J. Budinsky, L. Jenkins, E. Campbell, I. H. Barlow, R. Smith. Radiometric (eU) analyses by J. H. Goode, Jr., B. A. McCall]

\begin{tabular}{|c|c|c|c|c|c|c|c|c|c|}
\hline \multirow[t]{3}{*}{$1-78 \ldots$} & $26.6-35.4$ & A. & 7.6 & 31.2 & 44.7 & 3.6 & & 0.019 & 0.019 \\
\hline & & & 2.3 & & 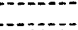 & & & & .008 \\
\hline & & & $\begin{array}{r}2.8 \\
68.9\end{array}$ & 31.6 & 44.3 & 3.6 & & & $<013$ \\
\hline \multirow[t]{3}{*}{$1-79$} & $35.4-43.3$ & & 4.8 & 22.4 & 41.4 & 2.5 & & & .014 \\
\hline & & & 38.6 & & & & & .003 & .002 \\
\hline & & & $\begin{array}{l}10.9 \\
31.6\end{array}$ & 30.5 & 46.8 & 3.4 & & & .011 \\
\hline \multirow[t]{3}{*}{$2-80 \ldots \ldots$} & $38.7-48.6$ & & $\begin{array}{l}26.2 \\
12.5\end{array}$ & 32.7 & 46.9 & 3.6 & & 013 & .015 \\
\hline & & & $\begin{array}{r}11.6 \\
6.0\end{array}$ & $\begin{array}{l}18.6 \\
33.1\end{array}$ & $\begin{array}{l}28.9 \\
47.4\end{array}$ & $\begin{array}{l}2.2 \\
3.7\end{array}$ & 6 & 06 & $\begin{array}{l}.007 \\
.013\end{array}$ \\
\hline & $48.6-50.2$ & & 43.7 & 24.6 & 431 & & & & К.001 \\
\hline \multirow{2}{*}{$2-81 \ldots \ldots$} & \$o. $0=00.2$ & & 13.8 & 18. 6 & 34.0 & 2.4 & & & .009 \\
\hline & & & $\begin{array}{l}15.7 \\
15.7\end{array}$ & 29.6 & 44.2 & 3.2 & & 010 & .002 \\
\hline \multirow[t]{3}{*}{$3-82$} & 23. 6-38.9 & & $\begin{array}{l}34.9 \\
19.6\end{array}$ & 31.6 & 45.7 & 3.7 & & & .014 \\
\hline & & $\mathrm{D}-$ & 9.8 & 12.7 & 17.7 & 1.3 & 12. 5 & 006 & .007 \\
\hline & & & $\begin{array}{r}9.8 \\
46.8\end{array}$ & 26.7 & 36.4 & 3.8 & & & .010 \\
\hline \multirow[t]{3}{*}{$3-83 \ldots$} & $42.6-53.0$ & & 12.1 & 29.6 & 43.7 & 3.1 & & & .010 \\
\hline & & & 24.5 & - & 4 & & & 1 & .002 \\
\hline & & & $\begin{array}{r}8.8 \\
30.7\end{array}$ & 31.5 & 44.8 & 3.5 & & & .009 \\
\hline \multirow[t]{3}{*}{$3-84$} & 53. 0-59.3 & & 5.8 & 28.0 & 42.4 & 3.1 & & & .012 \\
\hline & & & 28.0 & & & & & & .001 \\
\hline & & & 8.6 & 30.8 & 44.6 & 3.4 & & & .007 \\
\hline \multirow[t]{3}{*}{$5-85 \ldots$} & 17. 7-28.7 & & 15.9 & 28.7 & 40.6 & 2.7 & & & .014 \\
\hline & & & 32.1 & - & - & & & 003 & .007 \\
\hline & & & $\begin{array}{r}2.8 \\
37.3\end{array}$ & 32.5 & 46.5 & 3.7 & & & $<.012$ \\
\hline \multirow[t]{3}{*}{$586 \ldots$} & 28. 7-51. 4 & & 3.5 & 27.0 & 42.7 & 3.1 & & & .010 \\
\hline & & & $\begin{array}{l}19.4 \\
23.8\end{array}$ & (n) & (n) & $\ldots$ & & & .002 \\
\hline & & & $\begin{array}{l}10.7 \\
42.6\end{array}$ & 32.7 & 47.1 & 3.7 & - & 6 & .008 \\
\hline \multirow[t]{3}{*}{5.87} & $51.4-57.4$ & & 8.1 & 24.1 & 41.5 & 2.8 & & & .009 \\
\hline & & & $\begin{array}{l}22.9 \\
16.4\end{array}$ & & & & & .003 & .003 \\
\hline & & & 10.5 & 30.4 & 54.5 & 3.5 & & & .009 \\
\hline \multirow[t]{3}{*}{$677 \ldots$} & $31.4-39.3$ & A- & 11.5 & 22.4 & 40.7 & 2.7 & & & .011 \\
\hline & & D. & $\begin{array}{r}10.6 \\
5.1\end{array}$ & $\begin{array}{r}6.0 \\
28.2\end{array}$ & $\begin{array}{l}23.5 \\
41.2\end{array}$ & $\begin{array}{l}.8 \\
3.4\end{array}$ & & -- & $\begin{array}{l}.004 \\
.004 \\
.010\end{array}$ \\
\hline & & & 58.5 & & & & & & $<.001$ \\
\hline
\end{tabular}


CORE DRILLING, LAND-PEBBLE PHOSPHATE DISTRICT, FLORIDA 277

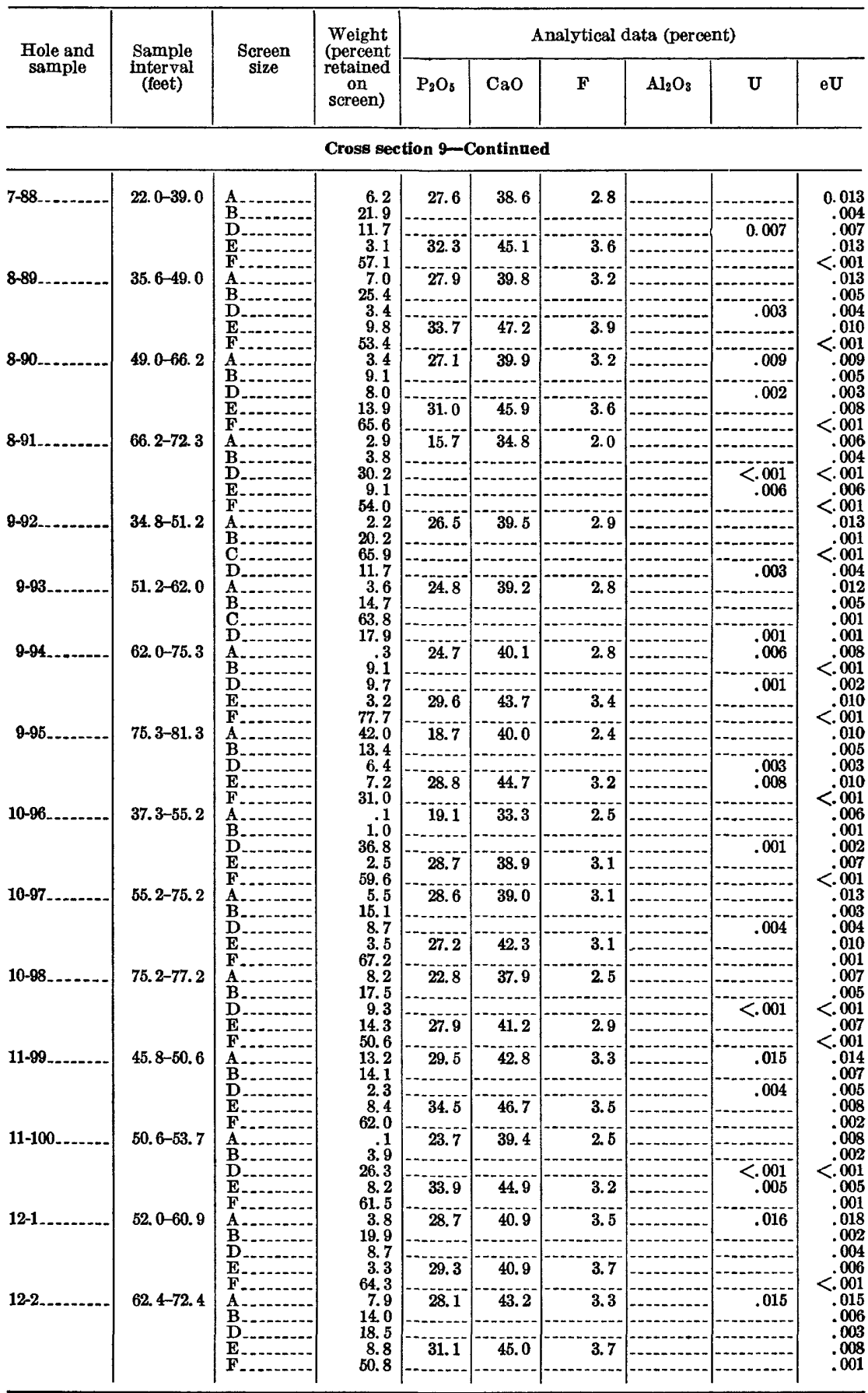




\begin{tabular}{c|c|c|c|c|c|c|c|c|c}
\hline $\begin{array}{c}\text { Hole and } \\
\text { sample }\end{array}$ & $\begin{array}{c}\text { Sample } \\
\text { interval } \\
\text { (feet) }\end{array}$ & $\begin{array}{c}\text { Screen } \\
\text { size }\end{array}$ & $\begin{array}{c}\text { Weight } \\
\text { (percent } \\
\text { retained } \\
\text { on } \\
\text { screen) }\end{array}$ & $\mathrm{P}_{2} \mathrm{O}_{3}$ & $\mathrm{CaO}$ & $\mathrm{F}$ & $\mathrm{Al}_{2} \mathrm{O}_{3}$ & $\mathrm{U}$ & $\mathrm{eU}$ \\
\hline
\end{tabular}

Cross section 10

[All samples are from lot 2546. Chemical analyses by R. Moore, L. Jenkins, I. H. Barlow, R. Smith. J. Smith, W. P. Tucker, J. Budimsky, E. Campbell, A. Sweeney, T. Murphy, J. Waring. Radiometric (eU) analyses by J. H. Goode, Jr., B. A. McCall]

\begin{tabular}{|c|c|c|c|c|c|c|c|c|c|}
\hline \multirow[t]{3}{*}{$1-101$} & 5.3-12. 6 & A. & 0.6 & 28.0 & 39.2 & 3.2 & & & 0.012 \\
\hline & & & $\begin{array}{l}13.2 \\
38.0\end{array}$ & & & & & $009^{-1}$ & .010 \\
\hline & & & 13.0 & 34.6 & 47.9 & 3.8 & & & .012 \\
\hline \multirow[t]{3}{*}{$1-102 \ldots$} & $12.6-18.9$ & & 2.8 & 29.7 & 44.3 & 3.1 & & & .009 \\
\hline & & & $\begin{array}{l}20.0 \\
20.3\end{array}$ & $\cdots$ & & & & 004 & .004 \\
\hline & & & $\begin{array}{l}24.4 \\
25.0\end{array}$ & 32.4 & 47.7 & 3.6 & & & .007 \\
\hline \multirow[t]{2}{*}{$2-105$} & 9. $6-17.1$ & & $\begin{array}{r}9.2 \\
10.8\end{array}$ & 31.6 & 45.2 & 3.8 & & .016 & .017 \\
\hline & & & $\begin{array}{l}10.8 \\
21.8 \\
24.0\end{array}$ & $\begin{array}{l}17.3 \\
33.7\end{array}$ & $\begin{array}{l}25.4 \\
49.7\end{array}$ & $\begin{array}{l}2.0 \\
4.0\end{array}$ & 7.8 & 010 & .011 \\
\hline \multirow[t]{3}{*}{$3-3 . \ldots$} & $27.5-37.0$ & & $\begin{array}{r}34.4 \\
6.2\end{array}$ & 30.2 & 44.7 & 3.5 & & . 014 & .016 \\
\hline & & & 14.2 & $-\cdots-$ & (n........... & $\cdots$ & & & .006 \\
\hline & & & 13.5 & 31.3 & 47.2 & 3.4 & & $\cdots$ & .010 \\
\hline \multirow[t]{2}{*}{$4-4 \ldots$} & $17.4-26.6$ & & $\begin{array}{l}38.3 \\
13.0\end{array}$ & 30.9 & 45.9 & 3.6 & & 6 & $\begin{array}{l}.001 \\
.022\end{array}$ \\
\hline & & & $\begin{array}{l}1.0 \\
24.7\end{array}$ & 15.9 & 26.4 & 2.0 & 0 & .014 & .013 \\
\hline \multirow{3}{*}{ 5-5 } & $22.4-26.0$ & & $\begin{array}{r}36.2 \\
2.9\end{array}$ & 30.3 & 41.6 & 3.3 & & & $\begin{array}{r}.001 \\
.009\end{array}$ \\
\hline & & & $\begin{array}{r}9.2 \\
65.1\end{array}$ & - & & & & & .004 \\
\hline & & & $\begin{array}{l}0.1 \\
22.8\end{array}$ & 12.8 & 12.4 & 1.2 & 17.3 & - & .005 \\
\hline \multirow[t]{3}{*}{$5-6 \ldots \ldots$} & $31.2-34.8$ & & $\begin{array}{l}12.8 \\
14.8\end{array}$ & 29.0 & 43.8 & 3.4 & & & $\begin{array}{l}.010 \\
.007\end{array}$ \\
\hline & & & $\begin{array}{l}34.2 \\
16.0\end{array}$ & 29.7 & 44.7 & 3.6 & & & .003 \\
\hline & $35.0-39.8$ & F. & 22.3 & 10.6 & 9.5 & 1.1 & & & .002 \\
\hline \multirow{2}{*}{ 6-7 } & $30.0-38.8$ & & 7.4 & & & & & & $\cdot 0$ \\
\hline & & $\mathrm{D}$ & $\begin{array}{r}83.3 \\
9.3\end{array}$ & 25.6 & .7 & 1.1 & 32.0 & $.050^{-1}$ & .029 \\
\hline \multirow{2}{*}{$6-8 \ldots$} & 41. $7-56.1$ & & $\begin{array}{r}1.9 \\
11.9\end{array}$ & 29.9 & 44.1 & 3.6 & $\cdots$ & .002 & $\begin{array}{l}.013 \\
.002\end{array}$ \\
\hline & & & $\begin{array}{r}36.1 \\
9.5\end{array}$ & 32.1 & 45.9 & 3.7 & & & $\begin{array}{r}.004 \\
.010 \\
.001\end{array}$ \\
\hline \multirow[t]{3}{*}{$6-9 \ldots \ldots$} & $56.1-60.9$ & & $\begin{array}{r}1.0 \\
1.0\end{array}$ & 24.7 & 40.1 & 2.9 & & - & $\begin{array}{l}.010 \\
.004\end{array}$ \\
\hline & & & 43.3 & (n) & - & 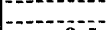 & & - & .001 \\
\hline & & & $\begin{array}{r}9.6 \\
29.7\end{array}$ & 30.1 & 45.8 & 3.5 & & & .007 \\
\hline \multirow[t]{2}{*}{$7-10$} & $7.0-22.0$ & & .2 & 10.6 & 10.3 & 1.0 & $\cdots$ & -..... & .012 \\
\hline & & & 67.7 & & & & & & .002 \\
\hline \multirow[t]{2}{*}{$7-11$} & $22.0-28.1$ & & $\begin{array}{r}17.7 \\
5.8\end{array}$ & $\begin{array}{l}13.5 \\
30.3 \\
18.0\end{array}$ & $\begin{array}{l}10.7 \\
41.5 \\
26.2\end{array}$ & $\begin{array}{l}1.2 \\
2.2\end{array}$ & $\begin{array}{r}20.7 \\
\end{array}$ & $\begin{array}{l}.022 \\
.040 \\
.021\end{array}$ & .018 \\
\hline & & & 63.5 & 129 & 16.6 & 1.6 & 15.3 & .017 & .015 \\
\hline \multirow[t]{3}{*}{$7-12$} & 33. 1-43. 2 & & $\begin{array}{r}20.2 \\
7.6\end{array}$ & 22.5 & $\begin{array}{l}16.6 \\
38.8\end{array}$ & $\begin{array}{l}1.0 \\
2.7\end{array}$ & $\ldots$ & $.01 /$ & \\
\hline & & & $\begin{array}{r}6.0 \\
34.4\end{array}$ & -- & $\ldots$ & $\cdots$ & $-\cdots$ & 05 & \\
\hline & & & 12.6 & 30.8 & 46.5 & 3.5 & $\cdots$ & & .007 \\
\hline \multirow[t]{2}{*}{$8-13$} & 18. $0-22.9$ & & $\begin{array}{r}3.4 \\
3.3\end{array}$ & 13.0 & .3 & 1.4 & & (n) & .004 \\
\hline & & & $\begin{array}{l}11.3 \\
64.6\end{array}$ & (16 & 8 & 18 & 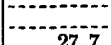 & 015 & .001 \\
\hline \multirow[t]{3}{*}{$8-14$} & $22.9-36.3$ & & $\begin{array}{r}20.8 \\
5.9\end{array}$ & $\begin{array}{l}16.9 \\
\mathbf{8 1 . 5}\end{array}$ & 42.2 & $\begin{array}{l}1.8 \\
3.4\end{array}$ & & & .010 \\
\hline & & & $\begin{array}{l}11.7 \\
21.1 \\
20.3\end{array}$ & $\begin{array}{l}15.7 \\
34.2\end{array}$ & $\begin{array}{l}18.4 \\
46.8\end{array}$ & $\begin{array}{l}1.8 \\
3.7\end{array}$ & 12.8 & .011 & .01 \\
\hline & & & 41.0 & & & & & & 60 \\
\hline
\end{tabular}


CORE DRILLING, LAND-PEBBLE PHOSPHATE DISTRICT, FLORIDA 279

\begin{tabular}{c|c|c|c|c|c|c|c|c|c}
\hline $\begin{array}{c}\text { Hole and } \\
\text { sample }\end{array}$ & $\begin{array}{c}\text { Sample } \\
\text { mterval } \\
\text { (feet) }\end{array}$ & $\begin{array}{c}\text { Screen } \\
\text { size }\end{array}$ & $\begin{array}{c}\text { Weight } \\
\text { (percent } \\
\text { retained } \\
\text { on } \\
\text { screen) }\end{array}$ & $\mathrm{P}_{2} \mathrm{O}_{3}$ & $\mathrm{CaO}$ & $\mathrm{F}$ & $\mathrm{Al}_{2} \mathrm{O}_{3}$ & $\mathrm{U}$ & $\mathrm{eU}$ \\
\hline
\end{tabular}

Cross section 10-Continued

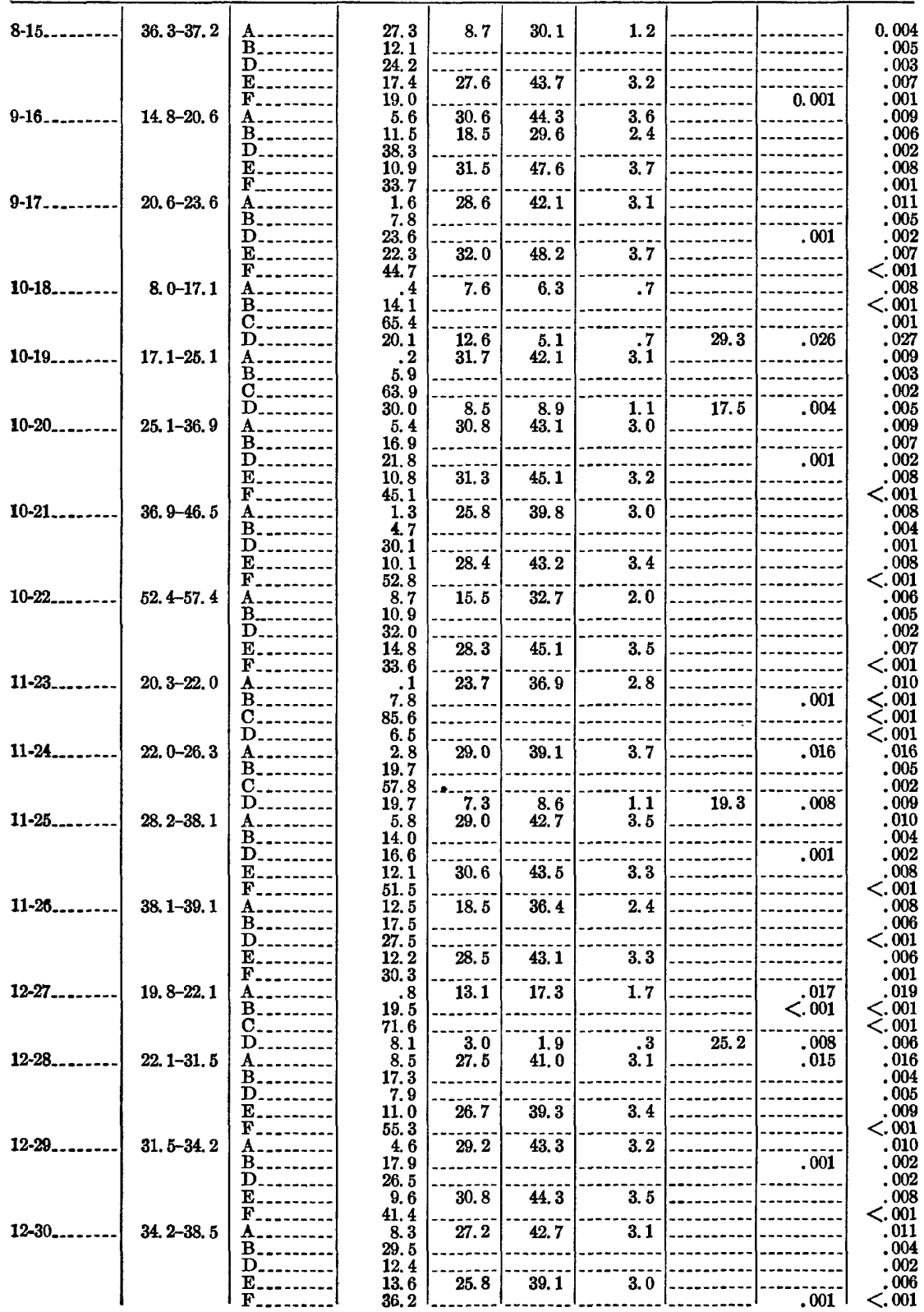




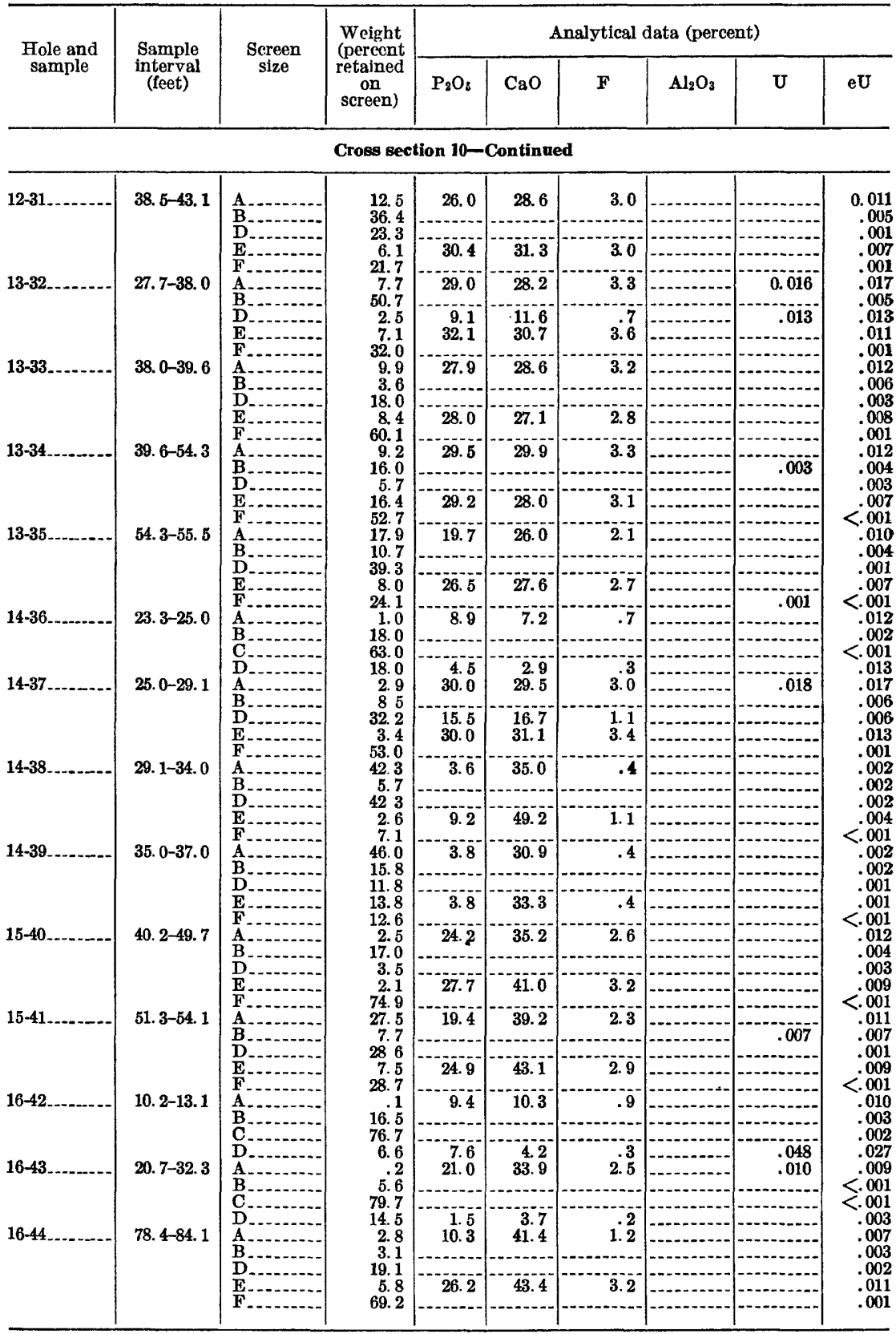


CORE DRILLING, LAND-PEBBLE PHOSPHATE DISTRICT, FLORIDA 281

\begin{tabular}{c|c|c|c|c|c|c|c|c|c}
\hline $\begin{array}{c}\text { Holn and } \\
\text { sample }\end{array}$ & $\begin{array}{c}\text { Sample } \\
\text { interval } \\
\text { (feet) }\end{array}$ & $\begin{array}{c}\text { Screen } \\
\text { size }\end{array}$ & $\begin{array}{c}\text { Weight } \\
\text { (percent } \\
\text { retained } \\
\text { on } \\
\text { screen) }\end{array}$ & $\mathrm{P}_{2} \mathrm{O}_{5}$ & $\mathrm{CaO}$ & $\mathrm{F}$ & $\mathrm{Al}_{2} \mathrm{O}_{3}$ & $\mathrm{U}$ & $\mathrm{eU}$ \\
\hline
\end{tabular}

\section{Cross section 11}

All samples are from lot 2546. Chemical analyses by G. J. Daniels, R. Moore, A. Sweeney, T. Murphy, J. Waring, J. Budinsky. Radiometric (eU) analyses by J. H. Goode, Jr., B. A. McCail]

\begin{tabular}{|c|c|c|c|c|c|c|c|c|c|}
\hline $1-45$. & $13.3-16.9$ & A. & 51.4 & 5.2 & 32.1 & 0.7 & & & 0.008 \\
\hline & & & 14.0 & & & - & & 5 & .006 \\
\hline & & & 3.3 & 4.4 & 33.5 & 6 & & & .004 \\
\hline $2-46$ & $18.6-32.0$ & A. & .9 & 8.9 & 3.3 & 4 & & & .003 \\
\hline & & & 70.5 & & & & & & 001 \\
\hline $2-47$. & $32.0-39.3$ & D. & $\begin{array}{r}9.5 \\
.3\end{array}$ & $\begin{array}{r}4.5 \\
13.8\end{array}$ & $\begin{array}{r}4.6 \\
11.8\end{array}$ & $\begin{array}{l}.3 \\
.7\end{array}$ & & & $\begin{array}{l}.018 \\
.008\end{array}$ \\
\hline & & & $\begin{array}{l}10.5 \\
79.0\end{array}$ & & & $\ldots$ & & 001 & $\begin{array}{l}<.001 \\
<.001\end{array}$ \\
\hline $2-48$ & 39. 3-41. 9 & & $\begin{array}{l}10.1 \\
16.6\end{array}$ & $\begin{array}{r}9.2 \\
30.4\end{array}$ & $\begin{array}{r}4.5 \\
44.3\end{array}$ & $\begin{array}{r}.4 \\
3.4\end{array}$ & & & $\begin{array}{l}.010 \\
.014\end{array}$ \\
\hline & & D & $\begin{array}{r}23.2 \\
3.9\end{array}$ & 6.9 & 8.9 & 4 & & & $\begin{array}{l}.006 \\
.006\end{array}$ \\
\hline & & $\frac{\mathbf{E}}{\mathbf{F}}$ & $\begin{array}{r}4.5 \\
51.8\end{array}$ & 32.6 & 47.5 & 3.7 & & & $\begin{array}{r}.013 \\
<.001\end{array}$ \\
\hline $3-49$ & 8. 9-21. 4 & $\mathrm{~A}$ & .2 & 13.0 & 11.9 & 1.1 & & & .006 \\
\hline & & $\mathrm{C}$ & 73. 0 & & & & & & $\because .001$ \\
\hline $3-50$ & $39.8-51.5$ & A. & $\begin{array}{l}25.2 \\
12.5\end{array}$ & $\begin{array}{l}11.5 \\
29.5\end{array}$ & $\begin{array}{r}9.6 \\
44.4\end{array}$ & 3.5 & & 19 & .020 \\
\hline & & D. & $\begin{array}{r}18.0 \\
9.5\end{array}$ & 11.9 & 16. 1 & 1.1 & & & .007 \\
\hline & & $\mathbf{E}$ & $\begin{array}{r}5.4 \\
54.6\end{array}$ & 30.7 & 46. 6 & 3. 7 & & $\cdots$ & .009 \\
\hline $3-51$ & $51.5-53.9$ & A. & 14. 0 & 24.8 & 41.7 & 3.2 & & & 001 \\
\hline & & $\mathrm{D}$ & $\begin{array}{r}14.0 \\
4.0\end{array}$ & - & $\ldots$ & & & & .004 \\
\hline & & $\frac{\mathbf{E}}{\mathbf{F}}$ & $\begin{array}{r}3.4 \\
64.6\end{array}$ & 26.3 & 41.6 & 3.3 & & & .007 \\
\hline $4-52 \ldots$ & 13. 0-23. 2 & $\mathbf{A}_{-}$ & $\begin{array}{r}.1 \\
8.0\end{array}$ & 13.7 & 15.4 & 1.5 & & & $\begin{array}{r}.006 \\
<.001\end{array}$ \\
\hline & & D & $\begin{array}{l}50.8 \\
41.1\end{array}$ & 10.1 & 5.4 & & & & .008 \\
\hline $4-53$ & $50.4-56.5$ & & 14. 9 & 17.1 & 42.9 & 3.0 & & $\cdots$ & .014 \\
\hline & & D & $\begin{array}{l}24.0 \\
26.4\end{array}$ & 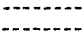 & 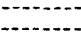 & & & & .000 \\
\hline & & $\mathbf{E}-$ & $\begin{array}{r}2.9 \\
31.8\end{array}$ & 31.0 & 48.1 & 3.7 & & & .010 \\
\hline b-54 & 5. 2-17. 4 & & 1.7 & (n) & 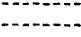 & $\cdots$ & & & .002 \\
\hline & & & $\begin{array}{r}8.8 \\
67.4\end{array}$ & 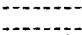 & 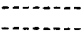 & $\cdots$ & & & $<.001$ \\
\hline 3-55 & $36.0-48.9$ & D. & $\begin{array}{r}22.1 \\
1.9\end{array}$ & $\begin{array}{r}7.3 \\
26.3\end{array}$ & $\begin{array}{r}.9 \\
39.1\end{array}$ & $\begin{array}{r}.3 \\
3.3\end{array}$ & & & $\begin{array}{l}.005 \\
.013\end{array}$ \\
\hline & & & $\begin{array}{r}27.2 \\
6.7\end{array}$ & - & 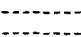 & & & & .002 \\
\hline & & $\mathbf{E}$ & $\begin{array}{r}3.2 \\
61.0\end{array}$ & 31.3 & 43.0 & 3.5 & & & $\begin{array}{r}.008 \\
<.001\end{array}$ \\
\hline 6-56.. & $12.9-19.8$ & & .1 & 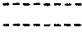 & n & $\cdots$ & & .004 & .005 \\
\hline & & & $\begin{array}{r}4.4 \\
72.5\end{array}$ & - n & 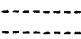 & $\cdots$ & & & $\begin{array}{l}<.001 \\
<.001\end{array}$ \\
\hline $6-57$. & 66. 6-70.2 & D & $\begin{array}{r}23.0 \\
1.2\end{array}$ & 16.9 & 36.1 & 2,0 & & 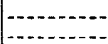 & $\begin{array}{l}.002 \\
.010\end{array}$ \\
\hline & & & 56.5 & & $\ldots+\ldots$ & $\ldots$ & & & .002 \\
\hline & & & $\begin{array}{r}10.0 \\
4.9\end{array}$ & 31.3 & 46.4 & 3.4 & & & .012 \\
\hline 7-58. & $34.9-49.9$ & $\mathrm{~F}^{\mathrm{A}}$ & $\begin{array}{r}23.9 \\
2.3\end{array}$ & 25.5 & 41.0 & 3.0 & & .012 & .001 \\
\hline & & & 42.9 & - & - n- & & & & $\boldsymbol{0}$ \\
\hline & & & $\begin{array}{l}4.4 \\
3.0\end{array}$ & 31.3 & 47.4 & 3.3 & & & .004 \\
\hline & & & 47. 4 & & & & & & 6001 \\
\hline 7-59. & $49.9-56.1$ & & $\begin{array}{l}16.0 \\
13.7\end{array}$ & 27.6 & 37.3 & 1.9 & & & .012 \\
\hline & & & $\begin{array}{r}13.7 \\
3.4\end{array}$ & - & . & $\ldots$ & & 002 & .003 \\
\hline 8-60_... & 20. $9-27.0$ & A.... & $\begin{array}{l}53.2 \\
22.4\end{array}$ & 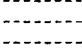 & 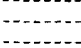 & 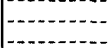 & & $-10-1$ & .002 \\
\hline & & B. & $\begin{array}{l}21.0 \\
50.4\end{array}$ & (n) & 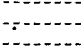 & 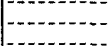 & & $-\cdots$ & $<.001$ \\
\hline & & & $\begin{array}{r}0.4 \\
6.2\end{array}$ & 15.8 & .5 & .1 & - & .005 & $\begin{array}{r}.005 \\
.005\end{array}$ \\
\hline
\end{tabular}




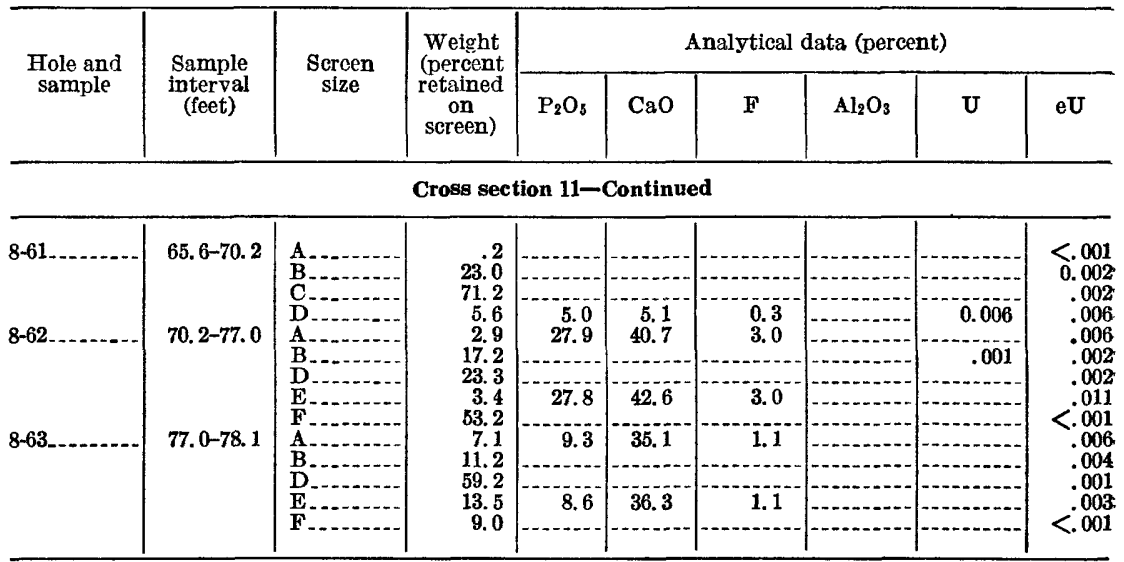

\section{Cross section 12}

[All samples are from lot 2546. Chemical analyses by G. J. Daniels, R. Moore, A. Sweeney, T. Murphy, J. Waring, J. Budinsky. Radiometric (eU) analyses by J. H. Goode, Jr., B. A. M cCall]

\begin{tabular}{|c|c|c|c|c|c|c|c|c|c|}
\hline \multirow[t]{2}{*}{$1-64$} & \multirow[t]{2}{*}{$6.0-11.0$} & A. & 9.3 & 14.4 & 2.9 & 0.3 & & 0.010 & 0.011 \\
\hline & & D. & $\begin{array}{r}36.2 \\
.9\end{array}$ & $\begin{array}{l}22.4 \\
17.5\end{array}$ & $\begin{array}{r}6.3 \\
13.3\end{array}$ & .8 & & $\begin{array}{l}.023 \\
.015\end{array}$ & $\begin{array}{l}.026 \\
.017\end{array}$ \\
\hline \multirow[t]{2}{*}{$1-65$} & \multirow[t]{2}{*}{$11.0-19.0$} & & 3.2 & 33.6 & 45.6 & 3.2 & & & .012 \\
\hline & & & $\begin{array}{r}25.0 \\
8.1\end{array}$ & $\begin{array}{l}23.6 \\
35.2\end{array}$ & $\begin{array}{l}21.4 \\
50.7\end{array}$ & $\begin{array}{l}1.4 \\
3.8\end{array}$ & & .014 & .014 \\
\hline \multirow[t]{3}{*}{$1-66 \ldots$} & \multirow[t]{3}{*}{$22.1-28.0$} & A. & 7. 3 & 34.8 & 50.6 & 4.0 & & .016 & .016 \\
\hline & & & 28. 3 & -1 & & & & .009 & .011 \\
\hline & & $\mathbf{E}$ & 24.8 & 37.5 & 52.0 & 4.3 & & .016 & .016 \\
\hline \multirow[t]{2}{*}{$2-67 \ldots \ldots$} & \multirow[t]{2}{*}{ 8. $5-17.2$} & A- & $\begin{array}{r}1.2 \\
30.4\end{array}$ & 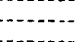 & - & 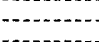 & & & $\begin{array}{r}005 \\
001\end{array}$ \\
\hline & & & 19.0 & 10.9 & 6.5 & .5 & & .017 & .019 \\
\hline \multirow[t]{2}{*}{$2-68$} & \multirow[t]{2}{*}{$17.2-26.5$} & & $\begin{array}{r}2.6 \\
15.8\end{array}$ & 33.4 & 48.1 & 4.0 & & .014 & .015 \\
\hline & & & $\begin{array}{l}32.7 \\
19.4\end{array}$ & 32.6 & 48.6 & 3. 6 & & .004 & .005 \\
\hline \multirow[t]{3}{*}{269} & \multirow[t]{3}{*}{$26.5-31.0$} & & 2.7 & 26.2 & 43.8 & 3.2 & & & .008 \\
\hline & & & 57.1 & 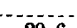 & - & 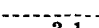 & $\ldots$ & & .001 \\
\hline & & & 20.7 & & & & & & .002 \\
\hline \multirow[t]{2}{*}{$3-70$} & \multirow[t]{2}{*}{ 8. $1-12.6$} & & $\begin{array}{r}6.5 \\
29.2\end{array}$ & (n) & (n........ & -............... & & $\cdots$ & .006 \\
\hline & & $\mathrm{D}$ & $\begin{array}{r}55.5 \\
8.7\end{array}$ & 22.7 & 4.2 & .5 & & .030 & $\begin{array}{l}.001 \\
.031\end{array}$ \\
\hline \multirow[t]{3}{*}{$3-71$} & \multirow[t]{3}{*}{$35.4-40.6$} & & 5.1 & 32.6 & 46.5 & 3.1 & & .034 & .036 \\
\hline & & & $\begin{array}{l}32.9 \\
10.0\end{array}$ & 17.3 & 23.1 & $\begin{array}{l}1.3 \\
3.4\end{array}$ & & .031 & $\begin{array}{l}.032 \\
.025\end{array}$ \\
\hline & & & 35.5 & 258 & 434 & 31 & & & .002 \\
\hline \multirow{2}{*}{$3-72 \ldots$} & \multirow{2}{*}{$40.7-43.1$} & & 2.9 & 20.8 & $\begin{array}{r}43.4 \\
-2 . \\
\end{array}$ & 0.1 & & & .008 \\
\hline & & & 14.5 & 30.1 & 47.9 & 3.6 & & & .011 \\
\hline \multirow[t]{2}{*}{$4-73 \ldots$} & \multirow[t]{2}{*}{$42.0-47.1$} & & $\begin{array}{r}21.0 \\
.1\end{array}$ & 18.8 & 27.7 & 2.1 & $\cdots$ & .002 & 012 \\
\hline & & & $\begin{array}{r}9.5 \\
75.6\end{array}$ & (n) & (n) & & & & $\begin{array}{l}<.001 \\
<.001\end{array}$ \\
\hline \multirow[t]{2}{*}{$4-74$} & \multirow[t]{2}{*}{$91.3-97.0$} & & $\begin{array}{r}14.8 \\
7.1\end{array}$ & 33.8 & 45.2 & 3.6 & & .013 & .014 \\
\hline & & & $\begin{array}{l}18.7 \\
11.7 \\
46.8\end{array}$ & $\begin{array}{l}16.9 \\
35.6\end{array}$ & $\begin{array}{l}23.8 \\
50.7\end{array}$ & $\begin{array}{l}1.5 \\
3.9\end{array}$ & 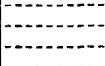 & $\begin{array}{l}.008 \\
.010\end{array}$ & .010 \\
\hline
\end{tabular}


CORE DRILLING, LAND-PEBBLE PHOSPHATE DISTRICT, FLORIDA 283

\begin{tabular}{|c|c|c|c|c|c|c|c|c|c|}
\hline \multirow{2}{*}{$\begin{array}{l}\text { Hole and } \\
\text { sample }\end{array}$} & \multirow{2}{*}{$\begin{array}{c}\text { Sample } \\
\text { interval } \\
\text { (feet) }\end{array}$} & \multirow{2}{*}{$\begin{array}{l}\text { Screen } \\
\text { size }\end{array}$} & \multirow{2}{*}{$\begin{array}{c}\text { Weight } \\
\text { (percent } \\
\text { retained } \\
\text { on } \\
\text { screen) }\end{array}$} & \multicolumn{6}{|c|}{ Analytical data (percent) } \\
\hline & & & & $\mathrm{P}_{2} \mathrm{O}_{5}$ & $\mathrm{CaO}$ & $\mathbf{F}$ & $\mathrm{Al}_{2} \mathrm{O}_{3}$ & $\mathrm{U}$ & eU \\
\hline \multicolumn{10}{|c|}{ Cross section 12-Continued } \\
\hline \multirow[t]{2}{*}{$4-75$} & $97.0-99.1$ & & $\begin{array}{r}1.2 \\
12.0\end{array}$ & $\begin{array}{l}32.0 \\
19.3\end{array}$ & $\begin{array}{l}46.3 \\
28.9\end{array}$ & $\begin{array}{l}3.6 \\
2.3\end{array}$ & & 0.020 & $\begin{array}{r}0.022 \\
.012\end{array}$ \\
\hline & & & 21.2 & 34.1 & 51.0 & 3.7 & $\cdots$ & .019 & 021 \\
\hline \multirow[t]{2}{*}{ 6-70........... } & $101.4-103.5$ & A & 52.1 & 23.7 & 42.2 & 3.1 & $-\cdots$ & - & .009 \\
\hline & & $\mathbf{D}$ & $\begin{array}{r}\text { 19. } \\
3.6 \\
15\end{array}$ & $\begin{array}{r}8.9 \\
28.9\end{array}$ & $\begin{array}{l}30.0 \\
45.6\end{array}$ & $\begin{array}{l}1.1 \\
3.2\end{array}$ & & .018 & $\begin{array}{l}020 \\
009\end{array}$ \\
\hline \multirow[t]{2}{*}{ 8-78 } & $50.9-59.9$ & A & 8.6 & 26.7 & 40.6 & 3.4 & $-\cdots$ & .014 & .016 \\
\hline & & O.-. & $\begin{array}{l}57.1 \\
19.8\end{array}$ & -........ & 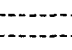 & & & .001 & .001 \\
\hline
\end{tabular}

\section{Cross section 13}

[All samples are from lot 2546. Chemical analyses by R. Moore, A. Sweeney, T. Murphy, J. Waring, J. Budinsky. Radiometric (eU) analyses by J. H. Goode, Jr., B. A. McCall]

\begin{tabular}{|c|c|c|c|c|c|c|c|c|c|}
\hline \multirow[t]{3}{*}{$1-79$} & $62.9-74.6$ & A. & 5.2 & 33.5 & 48.8 & 3.9 & -1 & & 0.010 \\
\hline & & & 17.4 & 344 & 482 & 20 & & 0.004 & .004 \\
\hline & & & 38.2 & 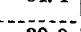 & 20.0 & 0.0 & & $<.00$ & $<.001$ \\
\hline \multirow{2}{*}{$2-80$} & $37.4-46.0$ & A.-. & $\begin{array}{l}12.1 \\
12.5\end{array}$ & 30.9 & $\begin{array}{c}46.5 \\
-\end{array}$ & 3.6 & & .010 & $\begin{array}{l}.015 \\
.012\end{array}$ \\
\hline & & & $\begin{array}{l}44.6 \\
13.5\end{array}$ & 32.9 & 47.5 & 3.8 &. & .009 & .007 \\
\hline \multirow[t]{3}{*}{$2-81 \ldots \ldots$} & $46.0-50.8$ & F. & $\begin{array}{r}17.3 \\
3.8\end{array}$ & 24.0 & 42.3 & 2.9 & & & $\begin{array}{l}.001 \\
.010\end{array}$ \\
\hline & & & $\begin{array}{r}9.4 \\
51.1\end{array}$ & & & & & ... & $\begin{array}{l}.007 \\
.002\end{array}$ \\
\hline & & & 13.6 & 29.9 & 46.7 & 3.5 & & 001 & .007 \\
\hline \multirow[t]{2}{*}{$3-82 \ldots$} & $75.8-81.2$ & A & 18.6 & 31.2 & 46.3 & 3.6 & & .017 & .020 \\
\hline & & & 18.6 & $\begin{array}{l}22.4 \\
33.5\end{array}$ & 32.2 & 2.2 & & .019 & .021 \\
\hline \multirow[t]{3}{*}{ 3-83_......... } & $81.6-85.8$ & & $\begin{array}{l}29.5 \\
13.2\end{array}$ & 31.2 & 46.7 & 3.6 & & .013 & .015 \\
\hline & & & $\begin{array}{l}11.8 \\
49.3\end{array}$ & 27.2 & 40.3 & 2.9 & & 004 & .010 \\
\hline & & & 13.7 & 32.2 & 47.2 & 3.4 & & .015 & .017 \\
\hline \multirow[t]{2}{*}{$3-84$} & $72.3-75.8$ & & $\begin{array}{r}.7 \\
4.8\end{array}$ & & & - & & & $\begin{array}{r}006 \\
.006\end{array}$ \\
\hline & & D. & $\begin{array}{l}8.4 \\
11.1\end{array}$ & 3.9 & 1.4 & .3 & & .014 & .015 \\
\hline $4-85$ & $66.3-70.0$ & & $\begin{array}{r}1.1 \\
74.0\end{array}$ & (n... & ( & $\cdots$ & & & .002 \\
\hline \multirow[t]{2}{*}{$4-87 \ldots$} & $70.0-75.0$ & D. & $\begin{array}{r}24.5 \\
.5 \\
11.8\end{array}$ & ( & & $\cdots$ & & .001 & $\begin{array}{l}.003 \\
.016\end{array}$ \\
\hline & $75.0-81.5$ & $\begin{array}{l}\mathrm{D}_{-}= \\
\mathrm{A}=-\end{array}$ & $\begin{array}{l}\text { 59. } \\
28.4 \\
11.9\end{array}$ & $\begin{array}{r}5.0 \\
29.6\end{array}$ & $\begin{array}{r}4.2 \\
43.7\end{array}$ & $\begin{array}{r}.4 \\
3.8\end{array}$ & & .021 & $\begin{array}{l}.004 \\
.024 \\
.007\end{array}$ \\
\hline 4-77 & & & $\begin{array}{r}5.0 \\
27.1\end{array}$ & $\begin{array}{l}17.9^{-} \\
29.8\end{array}$ & $\begin{array}{r}26.0 \\
42.3\end{array}$ & $\begin{array}{l}2.0 \\
3.6\end{array}$ & $\cdots$ & .008 & $\begin{array}{r}.010 \\
.006\end{array}$ \\
\hline \multirow[t]{2}{*}{ 4-86......... } & $91.1-94.3$ & A-: & $\begin{array}{l}43.8 \\
36.2\end{array}$ & 31.7 & 46.7 & 3.5 & & & .011 \\
\hline & & $\begin{array}{l}\text { B- } \\
\text { D. } \\
\text { E. }\end{array}$ & $\begin{array}{r}14.5 \\
11.6 \\
3.7\end{array}$ & $\begin{array}{l}22.0 \\
19.6 \\
31.2\end{array}$ & $\begin{array}{l}33.9 \\
34.6 \\
48.9\end{array}$ & $\begin{array}{l}2.8 \\
1.9 \\
4.0\end{array}$ & $-\cdots$ & .012 & $\begin{array}{r}<.001 \\
.010 \\
.013\end{array}$ \\
\hline \multirow[t]{3}{*}{$5-88$} & $80.9-85.9$ & F & $\begin{array}{r}34.0 \\
9.2\end{array}$ & 27.1 & 41.2 & & $\ldots$ & .006 & $\begin{array}{l}.007 \\
.012\end{array}$ \\
\hline & & & 10.7 & 21.3 & 31.3 & 2.3 & & & .012 \\
\hline & & $\mathbf{E}$ & $\begin{array}{r}.9 \\
61.7\end{array}$ & 30.9 & 46.6 & 3.4 & & .014 & $\begin{array}{l}.017 \\
.003\end{array}$ \\
\hline
\end{tabular}


284 CONTRIBUTIONS TO THE GEOLOGY OF URANIUM

\begin{tabular}{|c|c|c|c|c|c|c|c|c|c|}
\hline \multirow{2}{*}{$\begin{array}{l}\text { Hole and } \\
\text { sample }\end{array}$} & \multirow{2}{*}{$\begin{array}{c}\text { Sample } \\
\text { interval } \\
\text { (feet) }\end{array}$} & \multirow{2}{*}{$\begin{array}{c}\text { Screen } \\
\text { size }\end{array}$} & \multirow{2}{*}{$\begin{array}{l}\text { Weight } \\
\text { (percent } \\
\text { retained } \\
\text { on } \\
\text { screen) }\end{array}$} & \multicolumn{6}{|c|}{ Analytical data (percent) } \\
\hline & & & & $\mathrm{P}_{2} \mathrm{O}_{8}$ & $\mathrm{CaO}$ & $\mathbf{F}$ & $\mathrm{Al}_{2} \mathrm{O}_{3}$ & $\mathbf{U}$ & $\mathrm{eU}$ \\
\hline \multicolumn{10}{|c|}{ Cross section 13-Continued } \\
\hline $6-90$ & $67.4-71.6$ & $\begin{array}{l}\text { A. } \\
\text { B- } \\
\text { D. } \\
\mathbf{E}\end{array}$ & $\begin{array}{l}13.9 \\
17.7 \\
30.4 \\
11.3\end{array}$ & $\begin{array}{l}29.5 \\
23.4 \\
15.2 \\
32.1\end{array}$ & $\begin{array}{l}45.5 \\
35.4 \\
23.1 \\
47.4\end{array}$ & $\begin{array}{l}3.5 \\
2.8 \\
1.3 \\
3.7\end{array}$ & $\mid$\begin{tabular}{c}
$-\cdots$ \\
\hdashline$-\cdots$ \\
\hdashline..- \\
$-\cdots$
\end{tabular} & $\begin{array}{l}0.024 \\
.018 \\
.016 \\
.015\end{array}$ & $\begin{array}{r}0.026 \\
.018 \\
.015 \\
.018\end{array}$ \\
\hline $6-91 \ldots$ & $72.4-81.5$ & A- & 13.1 & 29.8 & 44.9 & 3.4 & $\cdots$ & .013 & .015 \\
\hline & & & $\begin{array}{l}10.5 \\
27.5 \\
13.5\end{array}$ & $\begin{array}{r}7.4 \\
29.4\end{array}$ & $\begin{array}{l}24.1 \\
44.4\end{array}$ & $\begin{array}{l}.8 \\
3.3\end{array}$ & & .009 & $\begin{array}{l}.009 \\
.007 \\
.008\end{array}$ \\
\hline 7-89.- & 76. $9-78.9$ & & $\begin{array}{l}19.7 \\
13.2 \\
13.2\end{array}$ & $\begin{array}{l}30.4 \\
12.8\end{array}$ & $\begin{array}{l}43.3 \\
23.3\end{array}$ & $\begin{array}{l}3.5 \\
1.6\end{array}$ & 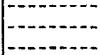 & .017 & $\begin{array}{l}.019 \\
.008\end{array}$ \\
\hline & & & 10.4 & 33.6 & 47.8 & 3.9 & - & & .012 \\
\hline 8-92-...- & $69.1-75.6$ & B... & $\begin{array}{r}.1 \\
.5 \\
80.0\end{array}$ & 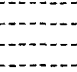 & - & & & .003 & $\begin{array}{l}.004 \\
.006 \\
.004 \\
.002\end{array}$ \\
\hline $8-93$ & $76.0-83.2$ & $\begin{array}{l}\text { A } \\
\text { A } \\
\text { B } \\
\text { D...... } \\
\text { D.... }\end{array}$ & $\begin{array}{r}19.4 \\
5.6 \\
4.4 \\
68.2 \\
21.8\end{array}$ & $\begin{array}{r}24.8 \\
20.8\end{array}$ & $\begin{array}{r}33.8 \\
30.4 \\
\end{array}$ & $\begin{array}{l}2.6 \\
2.5\end{array}$ & & $\begin{array}{l}.015 \\
.002\end{array}$ & $\begin{array}{l}.002 \\
.017 \\
.012 \\
.003 \\
.004\end{array}$ \\
\hline
\end{tabular}

Cross section 14

[Samples 94-100 are from lot 2546; samples 3 and 4 are from lot 2547. Chemical analyses by G. J. Daniels, R. Moore, A. Sweeney, T. Murphy, J. Waring, J. Budinsky. Radiometric (eU) analyses by J. H. Goode, Jr., and B. A. McCall]

\begin{tabular}{|c|c|c|c|c|c|c|c|c|c|}
\hline \multirow[t]{3}{*}{$1-94$} & $35.1-40.8$ & A. & $\begin{array}{l}0.4 \\
8.9\end{array}$ & & & & & & $\stackrel{0.001}{<001}$ \\
\hline & & $\mathrm{C}$ & 85.5 & & & & & & $<.001$ \\
\hline & $40.8-44.0$ & $\begin{array}{l}\mathbf{D} \\
\mathbf{A}\end{array}$ & $\begin{array}{l}5.2 \\
6.4\end{array}$ & $\begin{array}{l}16.8 \\
28.3\end{array}$ & $\begin{array}{r}8.2 \\
41.7\end{array}$ & $\begin{array}{l}0.8 \\
3.3\end{array}$ & & $\begin{array}{r}0.021 \\
.015\end{array}$ & $\begin{array}{l}.022 \\
.016\end{array}$ \\
\hline \multirow{2}{*}{$1-95$} & & B- & $\begin{array}{r}9.8 \\
10.9\end{array}$ & 24.0 & 35.3 & 1.9 & & ......... & $\begin{array}{l}.011 \\
.002\end{array}$ \\
\hline & & E & 20.3 & 34.3 & 48.5 & 3.7 & & 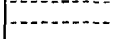 & .012 \\
\hline \multirow[t]{3}{*}{$1-96$} & $44.0-49.5$ & A & $\begin{array}{r}7.0 \\
7.6\end{array}$ & 20.8 & 29.4 & 2.3 & & - & .009 \\
\hline & & $\stackrel{\text { B- }}{\mathrm{D}}$ & $\begin{array}{r}5.6 \\
27.7\end{array}$ & 26.8 & 38.7 & 3.1 & & & $\begin{array}{l}.012 \\
.003\end{array}$ \\
\hline & & E. & $\begin{array}{l}24.4 \\
34.7\end{array}$ & 34.3 & 49.5 & 3. 9 & & & .013 \\
\hline \multirow[t]{2}{*}{$2-97$} & $40.5-43.6$ & A & .4 & 14. 4 & 18.3 & 1.4 & - & $\ldots$ & .010 \\
\hline & & C- & $\begin{array}{l}10.0 \\
69.2\end{array}$ & & & $\cdots$ & t & & $<.001$ \\
\hline \multirow[t]{3}{*}{$2-98}$. & $43.6-49.3$ & D. & $\begin{array}{l}14.8 \\
14.6\end{array}$ & $\begin{array}{r}4.4 \\
33.9\end{array}$ & $\begin{array}{r}5.1 \\
48.3\end{array}$ & $\begin{array}{r}3 \\
3.5\end{array}$ & & $\begin{array}{l}.018 \\
.018\end{array}$ & $\begin{array}{l}.018 \\
.018\end{array}$ \\
\hline & & $\frac{\mathrm{B}}{\mathrm{D}}$ & $\begin{array}{l}11.1 \\
21.8\end{array}$ & $\begin{array}{l}26.0 \\
17.1\end{array}$ & $\begin{array}{l}39.3 \\
25.1\end{array}$ & $\begin{array}{l}2.9 \\
1.5\end{array}$ & & .011 & $\begin{array}{l}.014 \\
.010\end{array}$ \\
\hline & & $\mathbf{F}$ & $\begin{array}{l}13.2 \\
39.3\end{array}$ & 33.5 & 50.0 & 3.8 & & & $\begin{array}{l}.009 \\
.003\end{array}$ \\
\hline \multirow[t]{3}{*}{$3-99 \ldots$} & $65.6-73.4$ & A & 5.8 & 26.8 & 42.6 & 3.3 & $\cdots$ & .020 & .022 \\
\hline & & D. & 17.5 & & & & & .003 & .004 \\
\hline & & $\frac{\mathrm{E}}{\mathrm{F}}$ & $\begin{array}{r}2.3 \\
68.0\end{array}$ & 27.2 & 32.8 & 3.3 & $\ldots$ & & $\begin{array}{l}.012 \\
.002\end{array}$ \\
\hline \multirow[t]{3}{*}{$3-100 \ldots$} & $73.4-75.6$ & A & $\begin{array}{l}13.4 \\
11.3\end{array}$ & $\begin{array}{l}26.5 \\
16.9\end{array}$ & $\begin{array}{l}43.8 \\
28.7\end{array}$ & $\begin{array}{l}3.3 \\
2.1\end{array}$ & & .016 & $\begin{array}{l}.016 \\
.010\end{array}$ \\
\hline & & $\mathrm{D}$ & $\begin{array}{r}30.3 \\
7.8\end{array}$ & 215 & 51 & 7 & & & .008 \\
\hline & & & 37.2 & 21.5 & 51.1 & 2.7 & & & .008 \\
\hline \multirow[t]{3}{*}{$4-4$} & 58. $0-75.0$ & & .2 & & 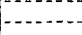 & $\cdots$ & & & .002 \\
\hline & & & 53.9 & -.. & $\ldots$ & - & & - & $\begin{array}{r}<.001 \\
.001\end{array}$ \\
\hline & & & $\begin{array}{r}23.6 \\
2.3\end{array}$ & 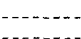 & $-\ldots+n$ & $-\ldots \ldots$ & $-\cdots$ & - & .002 \\
\hline \multirow{2}{*}{$8-3$} & $98.0-101.0$ & & $\begin{array}{r}2.3 \\
14.1\end{array}$ & & $-1-1,-1$ & & & 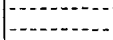 & $\begin{array}{l}.005 \\
.003\end{array}$ \\
\hline & & & $\begin{array}{l}73.5 \\
10.2\end{array}$ & 2.5 & 1.7 & .2 & & .047 & $\begin{array}{l}.002 \\
.046\end{array}$ \\
\hline
\end{tabular}


CORE DRILLING, LAND-PEBBLE PHOSPHATE DISTRICT, FLORIDA

\begin{tabular}{l|c|c|c|c|c|c|c|c|c}
\hline $\begin{array}{c}\text { Hole and } \\
\text { sample }\end{array}$ & $\begin{array}{c}\text { Sample } \\
\text { interval } \\
\text { (feet) }\end{array}$ & $\begin{array}{c}\text { Screen } \\
\text { size }\end{array}$ & $\begin{array}{c}\text { Weight } \\
\text { (percent } \\
\text { retained } \\
\text { on } \\
\text { screen) }\end{array}$ & $\mathrm{P}_{2} \mathrm{O}_{5}$ & $\mathrm{CaO}$ & $\mathrm{F}$ & $\mathrm{Al}_{2} \mathrm{O}_{3}$ & $\mathrm{U}$ & $\mathrm{eU}$ \\
\hline
\end{tabular}

Cross section 15

[All samples are from lot 2547. Chemical analyses by G. J. Daniels, A. Sweeney, W. P. Tucker, J. Budinsky. Radiometric (eU) analyses by J. H. Goode, Jr., B. A. McCall]

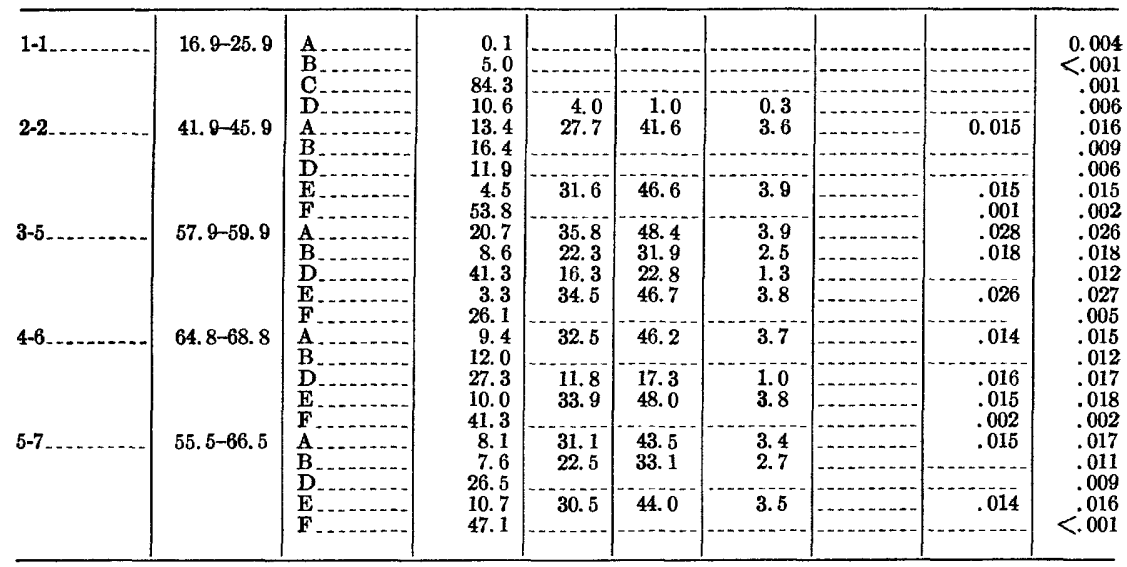

Cross section 16

[All samples are from lot 2547. Chemical analyses by G. J. Daniels, W. P. Tucker, J. Budinsky. Radiometric (eU) analyses by J. H. Goode, Jr., B. A. McCall]

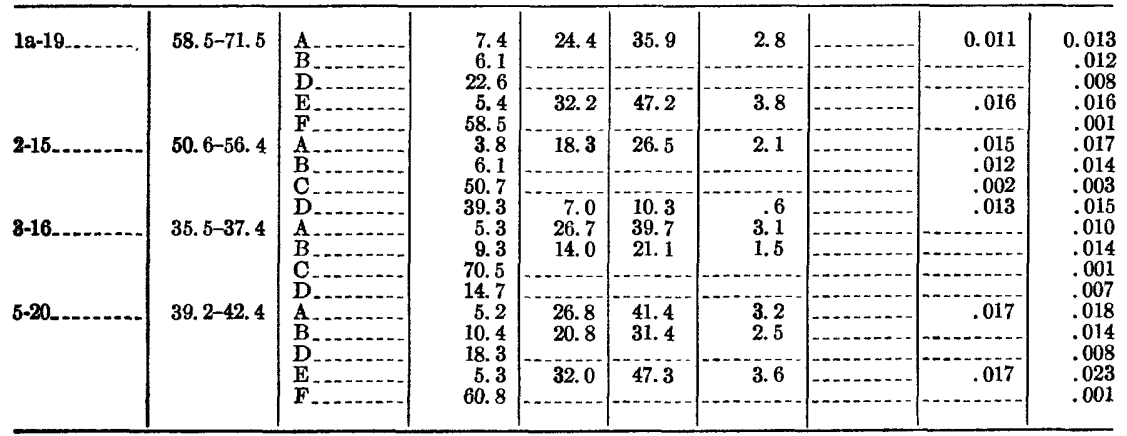




\begin{tabular}{c|c|c|c|c|c|c|c|c|c}
\hline $\begin{array}{c}\text { Hole and } \\
\text { sample }\end{array}$ & $\begin{array}{c}\text { Sample } \\
\text { interval } \\
\text { (feet) }\end{array}$ & $\begin{array}{c}\text { Screen } \\
\text { size }\end{array}$ & $\begin{array}{c}\text { Weight } \\
\text { (percent } \\
\text { retained } \\
\text { on } \\
\text { screen) }\end{array}$ & $\mathrm{P}_{2} \mathrm{O}_{5}$ & $\mathrm{CaO}$ & $\mathrm{F}$ & $\mathrm{Al}_{2} \mathrm{O}_{3}$ & $\mathrm{U}$ & $\mathrm{eU}$ \\
\hline
\end{tabular}

Cross section 17

[All samples are from lot 2547. Chemical analyses by G. J. Daniels, A. Sweeney, W. P. Tucker,'J. Budinsky. Radiometric (eU) analyses by J. H. Goode, Jr., B. A. McCall]

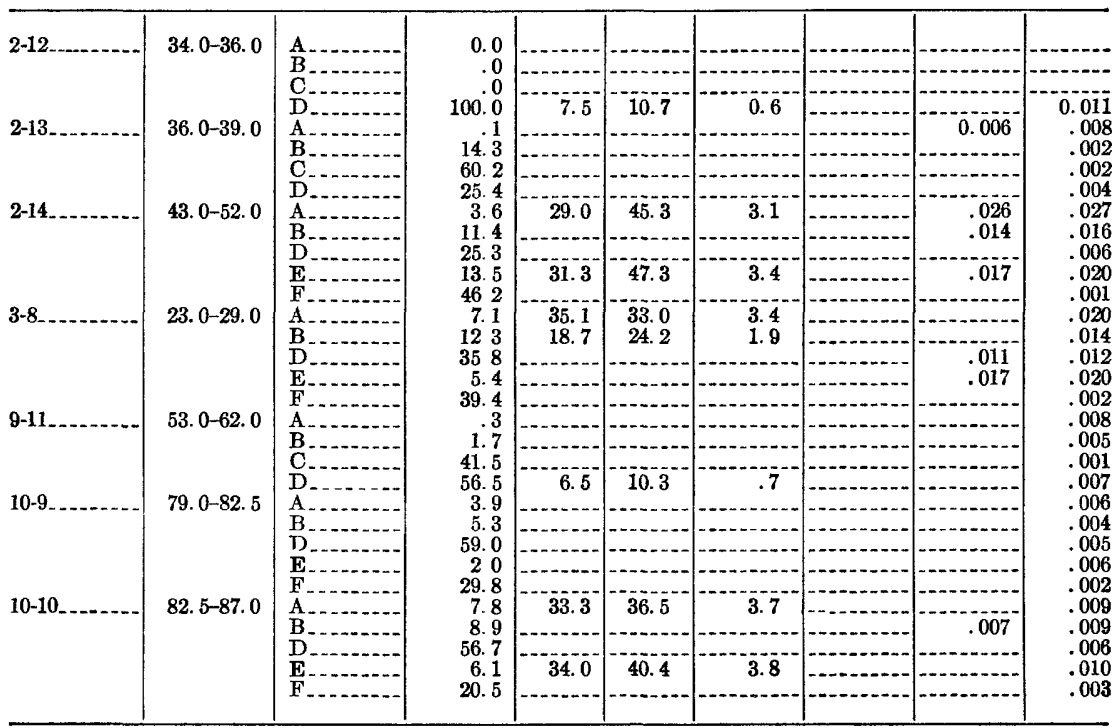

\section{Cross section 18}

[Both samples are from lot 2547. Chemical analyses by G. J. Daniels, A. Sweeney, W. P. Tucker, J. Budinsky. Radiometric (eU) analyses by J. H. Goode, Jr., B. A. McCall]

\begin{tabular}{|c|c|c|c|c|c|c|c|c|c|}
\hline $1-17$ & $23.0-31.0$ & A & 11.6 & 36.8 & 48.8 & 3. 7 & - & 0.016 & 0.015 \\
\hline & & $\mathrm{D}$ & $\begin{array}{l}35.1 \\
10.6\end{array}$ & $\begin{array}{l}23.5 \\
36.5\end{array}$ & $\begin{array}{l}32.4 \\
50.0\end{array}$ & $\begin{array}{l}1.8 \\
3.9\end{array}$ & 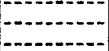 & .015 & $\begin{array}{l}.010 \\
.018\end{array}$ \\
\hline \multirow[t]{2}{*}{1.18} & \multirow[t]{2}{*}{$31.0-36.1$} & & $\begin{array}{r}7.1 \\
11.3\end{array}$ & $\begin{array}{l}35.7 \\
25.1\end{array}$ & $\begin{array}{l}48.4 \\
34.8\end{array}$ & $\begin{array}{l}3.7 \\
2.4\end{array}$ & & .015 & .018 \\
\hline & & E & $\begin{array}{r}49.0 \\
7.7 \\
24.3\end{array}$ & 35.2 & 49.5 & 3.7 & $\cdots$ & .016 & .018 \\
\hline
\end{tabular}


TONNAGE COMPUTATIONS FOR CROSS SECTIONS 1-18

[Percent U: Head assay calculated from analyses of individual fractions. Cpm: Counts per minute computed from gamma-ray log. Tons per acre: $\mathrm{P}$, pebble fraction $(+14 \mathrm{mesh}) ; \mathrm{C}$, concentrate fraction $(-35$ +150 mesh)]

\begin{tabular}{l|c|c|c|c|c|c|}
\hline & \multicolumn{2}{|c|}{ Aluminum phosphate zone } & Calcium phosphate & Remarks \\
Hole & $\begin{array}{c}\text { Depth } \\
\text { (feet below } \\
\text { the surface) }\end{array}$ & $\begin{array}{c}\text { Cubic } \\
\text { yards per } \\
\text { acre }\end{array}$ & $\begin{array}{c}\text { Percent } \\
\text { U }\end{array}$ & Cpm & $\begin{array}{c}\text { Tons per } \\
\text { acre }\end{array}$ & $\begin{array}{c}\text { Percent } \\
\text { bone } \\
\text { posphate } \\
\text { of lime }\end{array}$ \\
\hline
\end{tabular}

\section{Cross section 1}

[Chemical analyses by E. Campbell, L. Jenkins, I. H. Barlow, R. Smith, J. Smith, J. Budinsky. Radiometric (eU) analyses by B. A. McCall, J. H. Goode, Jr.]

\begin{tabular}{|c|c|c|c|c|c|c|c|}
\hline $\begin{array}{l}1 \\
2 \\
2 \\
3 \\
4 \\
5\end{array}$ & $\begin{array}{r}9.1-19.3 \\
7.0-9.1 \\
9.1-12.1 \\
20.5-22.0 \\
5.0-19.4 \\
\end{array}$ & $\begin{array}{r}16,320 \\
3,360 \\
2,400 \\
23,040 \\
\end{array}$ & $\begin{array}{r}0.007 \\
.011 \\
.003\end{array}$ & 800 & $130(\mathrm{P})$ & $\begin{array}{r}40.5 \\
\hdashline \ldots .0 . \\
\hdashline\end{array}$ & Blank hole. \\
\hline
\end{tabular}

\section{Cross gection 2}

[Ohemical analyses by E. Campbell, L. Jenkins, I. H. Barlow, R. Smith, J. Smith, W. P. Tucker, J. Budinsky. Radiometric (eU) analyses by B. A. McCall, J. H. Goode, Jr.]

\begin{tabular}{|c|c|c|c|c|c|c|c|}
\hline & $23.1-34.1$ & 17,600 & 0.010 & & & & \\
\hline 1. & $34.1-42,1$ & , & & & & & $\begin{array}{l}\text { Possible calcium phosphate } \\
\text { zone. Top contact taken } \\
\text { from gamma-ray log. Bot- } \\
\text { tom contact at base of lost } \\
\text { core. }\end{array}$ \\
\hline -..... & 131. $0-137.4$ & 10,240 & -........ & 1,100 & $\ldots$ & $\ldots$ & \\
\hline & $137.4-150.4$ & 11,520 & .010 & & & & $\begin{array}{l}\text { Possible calcium phosphate } \\
\text { zone. Not sampled, but } \\
\text { coarse phosphate pebble } \\
\text { present. Tonnage is low. }\end{array}$ \\
\hline & 31.0 & & & & & & $\begin{array}{l}\text { Base of sample 26. Samples } \\
\text { show phosphate nodules. } \\
\text { Not analyzed for } \mathrm{P}_{2} \mathrm{O}_{6} \text {. } \\
\text { Possible calcium phos } \\
\text { phate zone. Tonnage is } \\
\text { low. }\end{array}$ \\
\hline 4. & 17. $9-2 \mathrm{~L} .9$ & 6,400 & .003 & & & & \\
\hline
\end{tabular}

Cross section 3

[Chemical analyses by S. Bethea, E. Campbell, L. Jenkins, I. H. Barlow, R. Smith, J. Smith, W. P. Tucker, J. Budinsky. Radiometric (eU) analyses by B. A. MeCall, J. H. Goode, Jr. Holes 3, 4, and 5 had no aluminum phosphate or calcium phosphate.]

\begin{tabular}{r|r|r|r|r|r|r}
\hline 1 & $7.0-12.0$ & 8,000 & & 1,500 & & \\
$14.9-16.1$ & $\ldots 62(\mathrm{P})$ & 78.7 & \\
\hline & $10.3-18.1$ & 12.480 & 0.005 & & $231(\mathrm{C})$ & 79.6 \\
\hline
\end{tabular}




\begin{tabular}{l|l|c|c|c|c|c}
\hline & \multicolumn{2}{|c|}{ Aluminum phosphate zone } & Calcium phosphate & Remarks \\
Hole & $\begin{array}{c}\text { Depth } \\
\text { (feet below } \\
\text { the surface) }\end{array}$ & $\begin{array}{c}\text { Cubic } \\
\text { yards per } \\
\text { acre }\end{array}$ & $\begin{array}{c}\text { Percent } \\
\text { U }\end{array}$ & Cpm & $\begin{array}{c}\text { Tons per } \\
\text { acre }\end{array}$ & $\begin{array}{c}\text { Percent } \\
\text { bone } \\
\text { bhosphate } \\
\text { of lime }\end{array}$ \\
\hline
\end{tabular}

Cross section 4

[Chemical analyses by S. Bethea, E. Campbell, L. Jenkins, I. H. Barlow, R. Smith, J. Smith, W. P. Tucker, J. Budinsky. Radiometric (eU) analyses by B. A. McCall, J. H. Goode, Jr.]

\begin{tabular}{|c|c|c|c|c|c|c|c|}
\hline $\begin{array}{l}1 \\
1 \\
1\end{array}$ & $\begin{array}{l}\text { 10. 5-19.2 } \\
19.2-35.9 \\
35.9-39.9 \\
17.6-24.5 \\
21.2-28.6 \\
28.6-45.4\end{array}$ & $\begin{array}{r}13,920 \\
\end{array}$ & 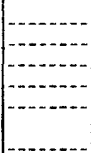 & 1,000 & $\begin{array}{l}1,168(\mathrm{P}) \\
187(\mathrm{P}) \\
270(\mathrm{P}) \\
1,530(\mathrm{P})\end{array}$ & $\begin{array}{r}76.5 \\
67.1 \\
63.5 \\
66.0\end{array}$ & $\begin{array}{l}\text { Possible calcium phosphate } \\
\text { zone. Not sampled. }\end{array}$ \\
\hline
\end{tabular}

\section{Cross section 5}

[Chemical analyses by S. Bethea, E. Campbell, L. Jenkins, I. H. Barlow, R. Smith, J. Smith, W. P. Tucker, J. Budinsky. Radiometric (eU) analyses by B. A. McCall, J. H. Goode, Jr.]

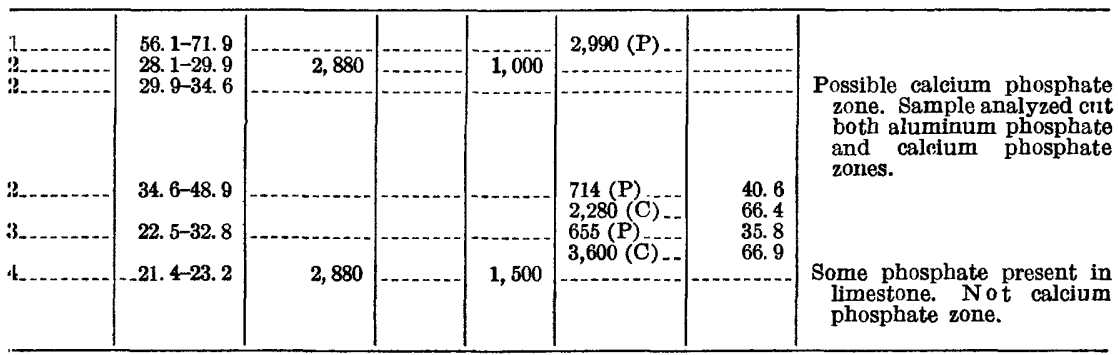

\section{Cross section 6}

I.Chemical analyses by R. Moore, J. Smith, W. P. Tucker, J. Budinsky, L. Jenkins, E. Campbell, I. H. Barlow, R. Smith. Radiometric (eU) analyses by J. H. Goode, Jr., B. A. McCall]

\begin{tabular}{|c|c|c|c|c|c|c|c|}
\hline & $22.6-37.6$ & 24,000 & 0.003 & & & & \\
\hline 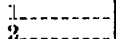 & 37. 6-44. 6 & $x=00$ & & & $1,020(\mathrm{P})$ & 69.5 & \\
\hline & $\begin{array}{l}21.0-27.1 \\
27.1-32.0\end{array}$ & 9,760 & .... & 900 & $530(\mathbf{P})$ & 72.6 & \\
\hline 3 & $62.9-67.2$ & 6,880 & & 800 & & & \\
\hline $3 \ldots \ldots$ & $67.2-68.8$ & & & & 440 (P) & 87.3 & \\
\hline 4 & $77.2-81.2$ & & & & $\cdots$ & $\cdots$ & $\begin{array}{l}\text { Possible calcium phosphate } \\
\text { zone. Not analyzed, over- } \\
\text { burden too thick, tonnage } \\
\text { too low to be economic. }\end{array}$ \\
\hline & $40.0-40.0$ & & & & 940 (C) & $\begin{array}{l}54.0 \\
73.8\end{array}$ & $\begin{array}{l}\text { Possible calcium phosphate } \\
\text { zone. Overburden too } \\
\text { thick, strata too thin to } \\
\text { be economic. }\end{array}$ \\
\hline
\end{tabular}


CORE DRILLING, LAND-PEBBLE PHOSPHATE DISTRICT, FLORIDA 289

\begin{tabular}{|c|c|c|c|c|c|c|c|}
\hline \multirow{2}{*}{ Hole } & \multirow{2}{*}{$\begin{array}{c}\text { Depth } \\
\text { interval } \\
\text { (feet below } \\
\text { the surface) }\end{array}$} & \multicolumn{3}{|c|}{ Aluminum phosphate zone } & \multicolumn{2}{|c|}{ Calcium phosphate } & \multirow{2}{*}{ Remarks } \\
\hline & & $\begin{array}{l}\text { Cubic } \\
\text { yards per } \\
\text { acre }\end{array}$ & $\underset{\mathrm{U}}{\text { Percent }}$ & $\mathrm{Cpm}$ & $\begin{array}{l}\text { Tons per } \\
\text { acre }\end{array}$ & $\begin{array}{c}\text { Percent } \\
\text { bone } \\
\text { phosphate } \\
\text { of lime }\end{array}$ & \\
\hline
\end{tabular}

Cross section 7

[Chemical analyses by R. Moore, J. Smith, W. P. Tucker, J. Budinsky, L. Jenkins, E. Campbell, I. H. Barlow, R. Smith. Radiometric (eU) analyses by J. H. Goode, Jr., B. A. MeCall]

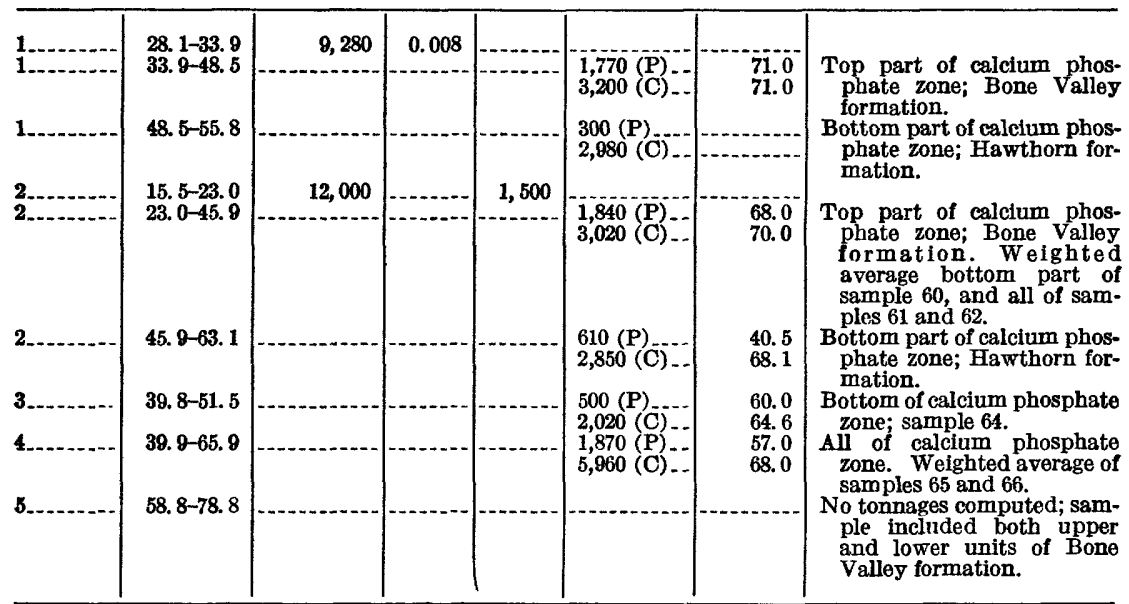

Cross section 8

[Chemical analyses by R. Moore, J. Smith, W. P. Tucker, J. Budinsky, L. Jenkins, E. Campbell, I. H. Barlow, R. Smith. Radiometric (eU) analyses by J. H. Goode, Jr., B. A. MeCall. No aluminum phosphate zone present in this line of drill holes]

\begin{tabular}{|c|c|c|c|c|c|c|c|}
\hline 1. & $51.0-83.0$ & & & & & & Top sample of calci \\
\hline & & & & & & & $\begin{array}{l}\text { phate zone; Bone Valley } \\
\text { formation. }\end{array}$ \\
\hline 1. & $83.0-94.0$ & & & & $\begin{array}{l}347(\mathrm{P})_{\ldots} \\
1,630(\mathrm{C})_{-.}\end{array}$ & $\begin{array}{l}40.3 \\
59.2\end{array}$ & $\begin{array}{l}\text { Bottom sample of calcium } \\
\text { phosphate zone; Hawthorn }\end{array}$ \\
\hline 2. & $39.2-52.4$ & & & & $\begin{array}{l}2,840(\mathrm{P}) \\
1,260(\mathrm{C})\end{array}$ & $\begin{array}{l}40.6 \\
68.9\end{array}$ & $\begin{array}{l}\text { Top sample of calcium phos- } \\
\text { phate zone; Bone Valley }\end{array}$ \\
\hline 2. & $52.4-87.5$ & & & & $\begin{array}{l}2,636(\mathrm{P}) \\
6,379(\mathrm{C}) \\
-\end{array}$ & $\begin{array}{l}29.4 \\
62.4\end{array}$ & $\begin{array}{l}\text { formation. } \\
\text { Bottom sample of calcium } \\
\text { phosphate zone; Hawthorn } \\
\text { formation. W eig hted } \\
\text { average of samples } 71,72 \text {, } \\
\text { and } 73 \text {. }\end{array}$ \\
\hline & & & & & $\begin{array}{l}6,075(\mathrm{P}) \\
450(\mathrm{C})\end{array}$ & $\begin{array}{l}30.2 \\
58.6\end{array}$ & $\begin{array}{l}\text { Total calcium phosphate } \\
\text { zone; Bone Valley forma- }\end{array}$ \\
\hline & $45.5-50.3$ & & & & $\begin{array}{l}1,800(P) \\
630(\mathrm{C})\end{array}$ & $\begin{array}{l}56.0 \\
65.6\end{array}$ & $\begin{array}{l}\text { Top sample of calcium phos. } \\
\text { phate zone; Bone Valley } \\
\text { formation. }\end{array}$ \\
\hline $4+\ldots+\ldots$ & $\begin{array}{l}50.3-56.1 \\
56.1-63.4\end{array}$ & & & & $1,470(\mathrm{P})$ & $\begin{array}{l}50.8 \\
65.6\end{array}$ & $\begin{array}{l}\text { Bottom sample of calcium } \\
\text { phosphate zone; Hawthorn } \\
\text { formation. }\end{array}$ \\
\hline
\end{tabular}




\begin{tabular}{|c|c|c|c|c|c|c|c|}
\hline \multirow{2}{*}{ Hole } & \multirow{2}{*}{$\begin{array}{c}\text { Depth } \\
\text { interval } \\
\text { (feet below } \\
\text { the surface) }\end{array}$} & \multicolumn{3}{|c|}{ Aluminum phosphate zone } & \multicolumn{2}{|c|}{ Calcium phosphate } & \multirow{2}{*}{ Remarks } \\
\hline & & $\begin{array}{l}\text { Cubic } \\
\text { yards per } \\
\text { acre }\end{array}$ & $\underset{\mathrm{U}}{\text { Percent }}$ & $\mathbf{C p m}$ & $\begin{array}{l}\text { Tons per } \\
\text { acre }\end{array}$ & $\begin{array}{c}\text { Percent } \\
\text { bone } \\
\text { phosphate } \\
\text { of lime }\end{array}$ & \\
\hline
\end{tabular}

\section{Cross section 9}

[Chemical analyses by G. J. Daniels, R. Moore, J. Smith, W. P. Tucker, J. Budinsky, L. Jenkins, E. Camplell, I. H. Barlow, R. Smith. Radiometric (eU) analyses by J. H. Goode, Jr., B. A. McCali]

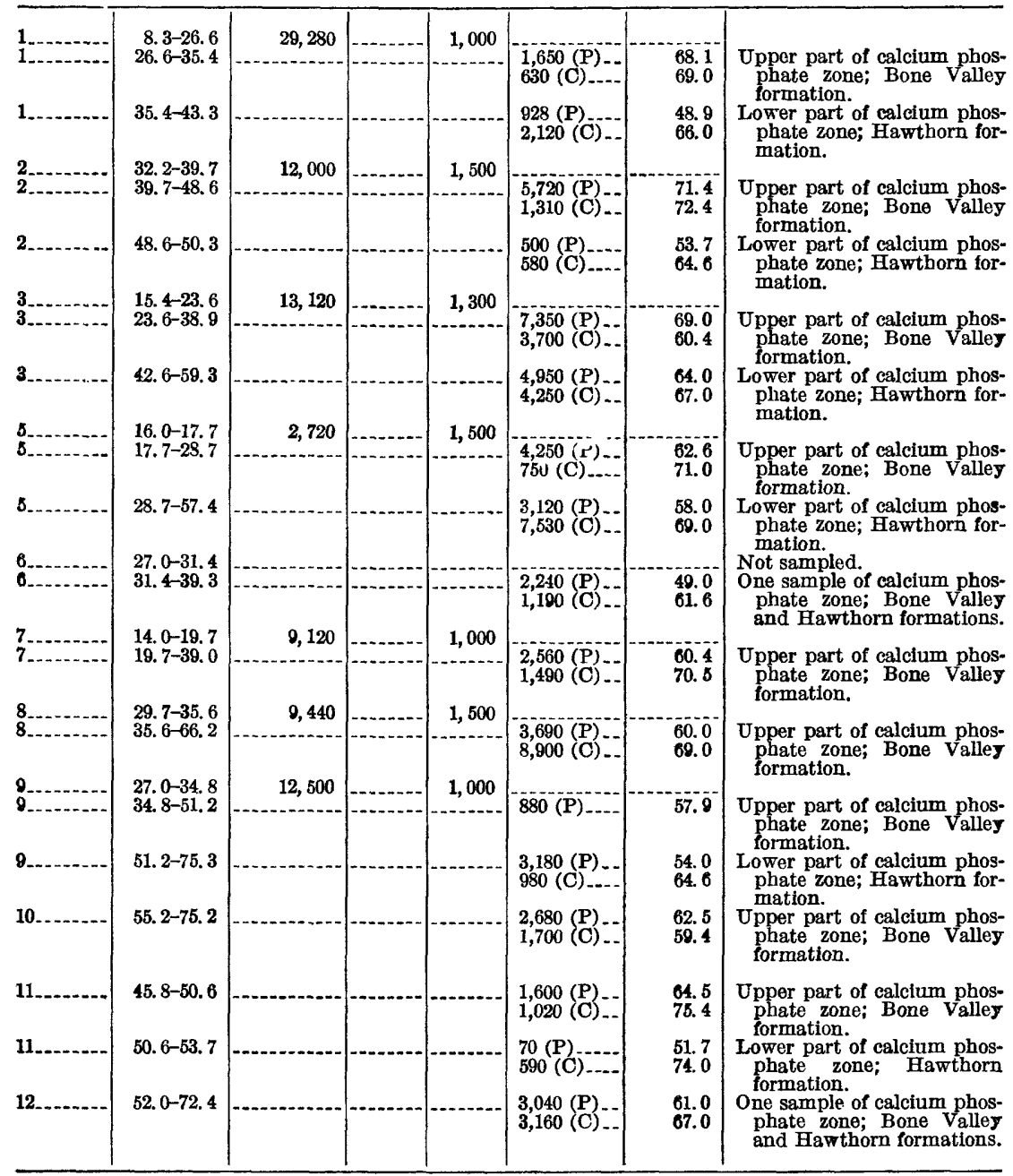




\begin{tabular}{|c|c|c|c|c|c|c|c|}
\hline \multirow{2}{*}{ Hole } & \multirow{2}{*}{$\begin{array}{c}\text { Depth } \\
\text { interval } \\
\text { (feet below } \\
\text { the surface) }\end{array}$} & \multicolumn{3}{|c|}{ Aluminum phosphate zone } & \multicolumn{2}{|c|}{ Calcium phosphate } & \multirow{2}{*}{ Remarks } \\
\hline & & $\begin{array}{l}\text { Cubic } \\
\text { yards per } \\
\text { acre }\end{array}$ & $\underset{\mathrm{U}}{\text { Percent }}$ & Cpm & $\begin{array}{l}\text { Tons per } \\
\text { acre }\end{array}$ & $\begin{array}{c}\text { Percent } \\
\text { bone } \\
\text { phosphate } \\
\text { of lime }\end{array} \mid$ & \\
\hline
\end{tabular}

Cross section 10

[Chemical ana]yses by R. Moore, L. Jenkins, I. H. Barlow, R. Smith, J. Smith, W. P. Tucker, J. Budinsky, E. Campbell, A. Sweeney, T. Murphy, J. Waring. Radiometric (eU) analyses by J. H. Goode, Jr., B. A. McCall]

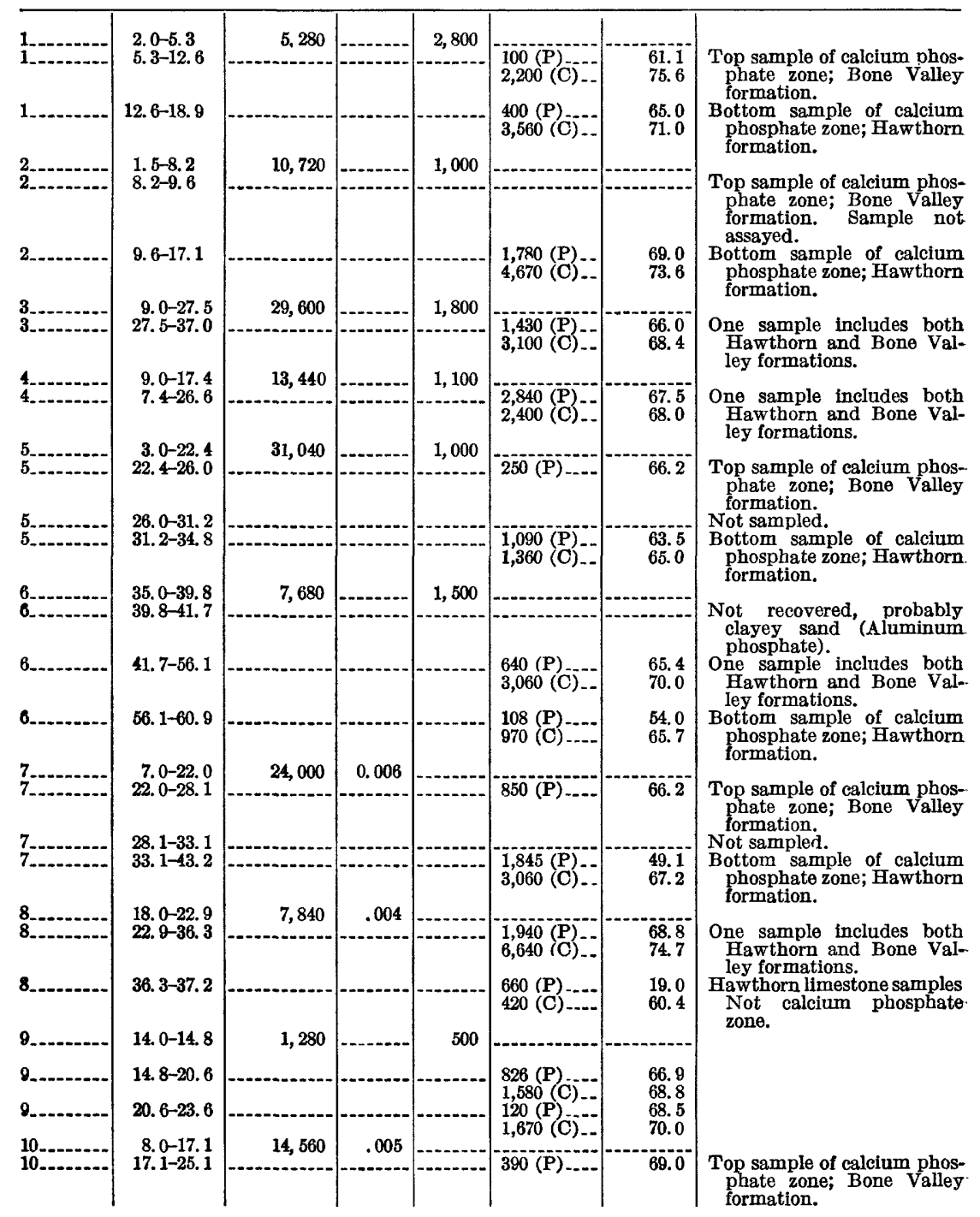




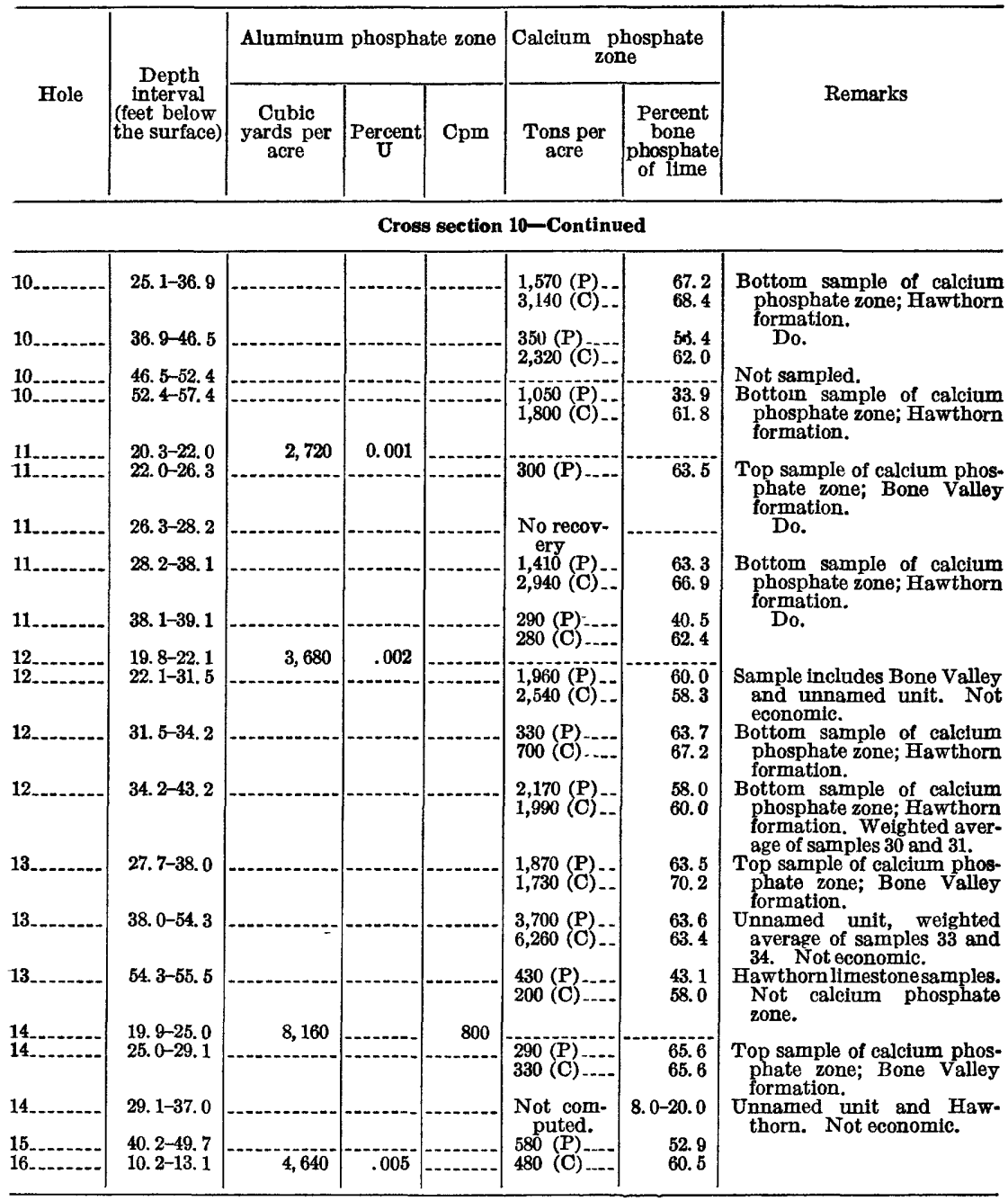

\section{Cross section 11}

[Chemical analyses by G. J. Daniels, R. Moore, A. Sweeney, T. Murphy, J. Waring, J. Budinsky. Radiometric (eU) analyses by J. H. Goode, Jr., B. A. McCall]

\begin{tabular}{|c|c|c|c|c|c|c|c|}
\hline & & & & & & & Blank hole. \\
\hline 2 & $22.5-28.0$ & 8,800 & -. & 1,000 & & & $\begin{array}{l}\text { Interval between aluminum } \\
\text { phosphate zone and cal- } \\
\text { cium phosphate zone is } \\
\text { clayey sand; not economic. }\end{array}$ \\
\hline & $39.3-41.8$ & $-\cdots-$ & & 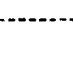 & $\begin{array}{l}1,010(P) \\
270(C)\end{array}$ & $\begin{array}{l}66.5 \\
71.2\end{array}$ & $\begin{array}{l}\text { Upper part of calcium phos- } \\
\text { phate zone; Bone Valley } \\
\text { formation. }\end{array}$ \\
\hline $3 \ldots$ & $21.3-24.4$ & 4,960 & & & & $-\cdots$ & $\begin{array}{l}\text { Interval between aluminum } \\
\text { phosphate zone and cal- } \\
\text { cium phcsphate zone is } \\
\text { clayey sand; not economic. } \\
\text { Aluminum phosphate zone } \\
\text { based on lithology; no } \\
\text { analysis or gamma-ray } \\
\text { data available. }\end{array}$ \\
\hline
\end{tabular}


CORE DRILLING, LAND-PEBBLE PHOSPHATE DISTRICT, FLORIDA 293

\begin{tabular}{|c|c|c|c|c|c|c|c|}
\hline \multirow{2}{*}{ Hole } & \multirow{2}{*}{$\begin{array}{c}\text { Death } \\
\text { interval } \\
\text { (feet below } \\
\text { the surface) }\end{array}$} & \multicolumn{3}{|c|}{ Aluminum phosphate zone } & \multicolumn{2}{|c|}{$\underset{\text { zone }}{\text { Calcium phosphate }}$} & \multirow{2}{*}{ Remarks } \\
\hline & & $\begin{array}{l}\text { Cubic } \\
\text { yards per } \\
\text { acre }\end{array}$ & $\begin{array}{c}\text { Percent } \\
\mathrm{U}\end{array}$ & Cpm & $\begin{array}{l}\text { Tons per } \\
\text { acre }\end{array}$ & $\begin{array}{c}\begin{array}{c}\text { Percent } \\
\text { bone } \\
\text { phosphate } \\
\text { of lime }\end{array} \\
0\end{array}$ & \\
\hline
\end{tabular}

Cross section 11-Continued

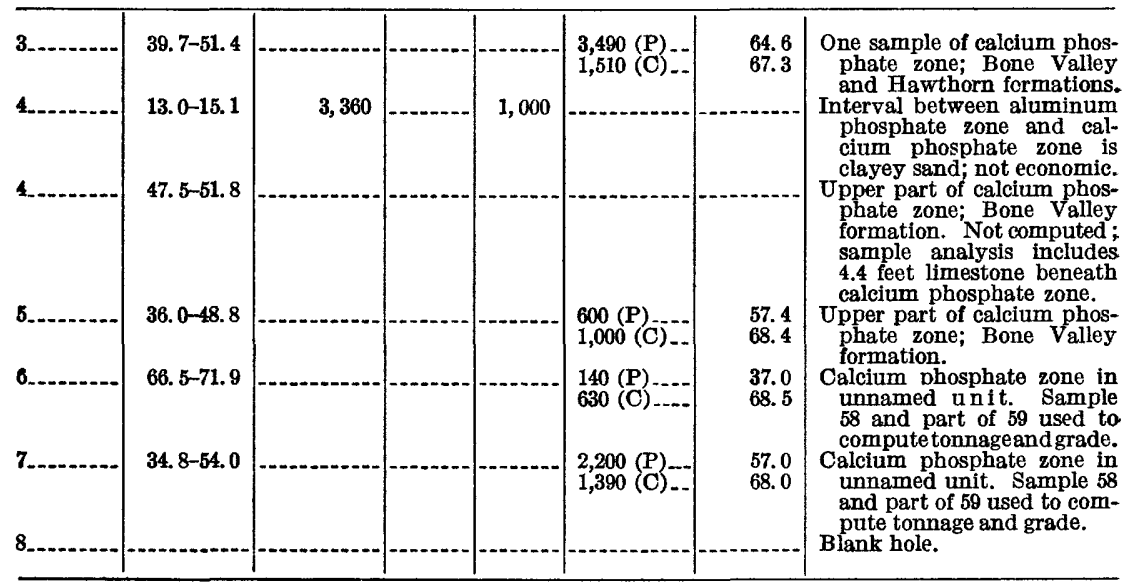

\section{Cross section 12}

[Chemical analyses by G. J. Daniels, R. Moore, A. Sweeney, T. Murphy, J. Waring, J. Budinsky. Radiometric (eU) analyses by J. H. Goode, Jr., B. A. McCall]

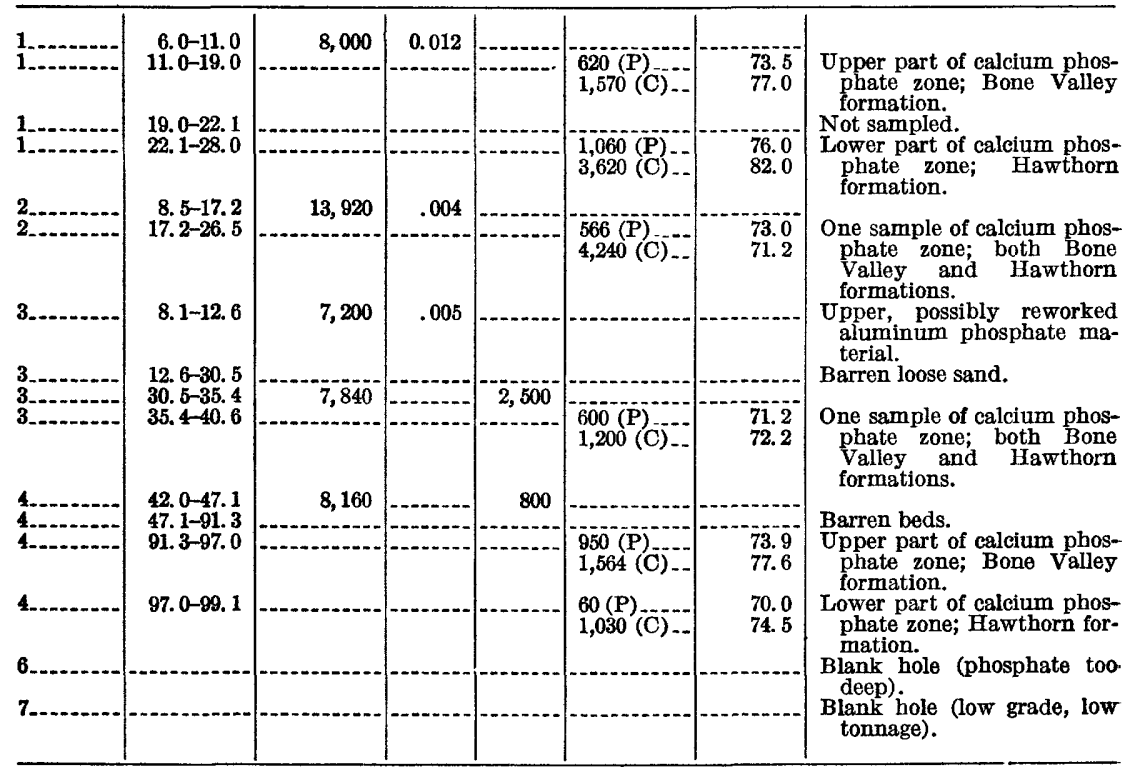




\begin{tabular}{|c|c|c|c|c|c|c|c|}
\hline \multirow{2}{*}{ Hole } & \multirow{2}{*}{$\begin{array}{c}\text { Death } \\
\text { interval } \\
\text { (feet below } \\
\text { the surface) }\end{array}$} & \multicolumn{3}{|c|}{ Aluminum phosphate zone } & \multicolumn{2}{|c|}{$\begin{array}{c}\text { Calcium phosphate } \\
\text { zone }\end{array}$} & \multirow{2}{*}{ Remarks } \\
\hline & & $\begin{array}{c}\text { Cubic } \\
\text { yards per } \\
\text { acre }\end{array}$ & $\left|\begin{array}{c}\text { Percent } \\
\mathrm{U}\end{array}\right|$ & Cpm & $\begin{array}{l}\text { Tons per } \\
\text { acre }\end{array}$ & $\begin{array}{c}\text { Percent } \\
\text { bone } \\
\text { phosphate } \\
\text { of lime }\end{array}$ & \\
\hline
\end{tabular}

\section{Cross section 13}

[Chemical analyses by R. Moore, A. Sweeney, T. Murphy, J. Waring, J. Budinsky. Radiometrio (eU) analyses by J. H, Goode, Jr., B. A. McCall

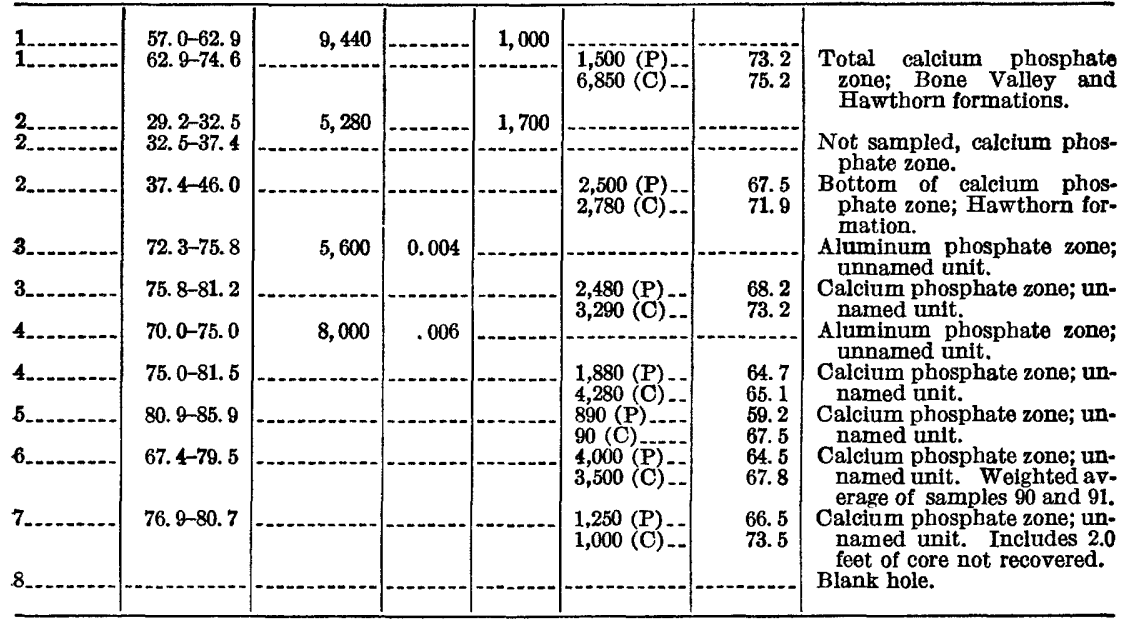

\section{Cross section 14}

[Chemfeal analyses by G. J. Daniels, R. Moore, A. Sweeney, T. Murphy, J. Waring, J. Budinsky. Radiometric (eU) analyses by J. H. Goode, Jr., B. A. MeCall. Holes 3, 4, 7, and 8 intersected no aluminum phosphate or calcium phosphate]

\begin{tabular}{|c|c|c|c|c|c|c|c|}
\hline & 38. $0-40.8$ & 4,480 & 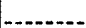 & 1,400 & & & \\
\hline $1 \ldots \ldots$ & $40.8-49.5$ & $\cdots$ & & & $\begin{array}{l}1,550(\mathrm{P}) \\
4,990(\mathrm{C})\end{array}$ & $\begin{array}{l}51.7 \\
75.0\end{array}$ & $\begin{array}{l}\text { One sample of calcium phos- } \\
\text { phate zone; Bone Valley }\end{array}$ \\
\hline $2 \ldots$ & $43.6-49.3$ & & & & $\begin{array}{l}2,130 \text { (P) } \\
1,920 \text { (C) } .-\end{array}$ & $\begin{array}{l}74.1 \\
73.2\end{array}$ & $\begin{array}{l}\text { Lower part of calcium phos- } \\
\text { phate zone; Hawthorn for- } \\
\text { mation. }\end{array}$ \\
\hline
\end{tabular}

\section{Cross section 15}

[Chemical analyses by G. J. Daniels, A. Sweeney, W. P. Tucker, J. Budinsky. Radiometeric (eU) analyses by J. H. Goode, Jr., B. A. McCall]

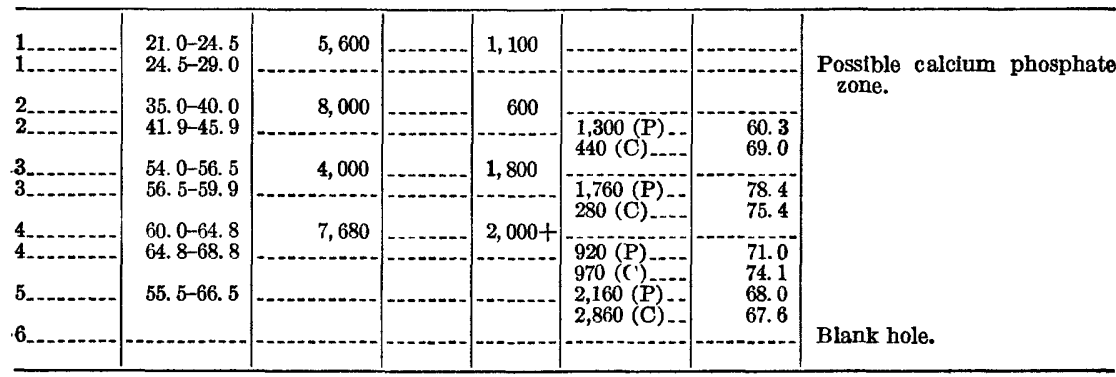


CORE DRILLING, LAND-PEBBLE PHOSPHATE DISTRICT, FLORIDA 295

\begin{tabular}{|c|c|c|c|c|c|c|c|}
\hline \multirow{2}{*}{ Hole } & \multirow{2}{*}{$\begin{array}{c}\text { Death } \\
\text { interval } \\
\text { (feet below } \\
\text { the surface) }\end{array}$} & \multicolumn{3}{|c|}{ Aluminum phosphate zone } & \multicolumn{2}{|c|}{$\begin{array}{c}\text { Calcium phosphate } \\
\text { zone }\end{array}$} & \multirow{2}{*}{ Remarks } \\
\hline & & $\begin{array}{l}\text { Cubic } \\
\text { yards per } \\
\text { acre }\end{array}$ & $\underset{\mathrm{U}}{\text { Percent }}$ & Cpm & $\begin{array}{l}\text { Tons per } \\
\text { acre }\end{array}$ & $\begin{array}{c}\text { Percent } \\
\text { bone } \\
\text { phosphate } \\
\text { of lime }\end{array}$ & \\
\hline
\end{tabular}

Crosis section 16

[Chemical analyses by G. J. Daniels, A. Sweeney, W. P. Tucker, J. Budinsky. Radiometric (eU) analyses by J. H. Goode, Jr., B. A. MeCall

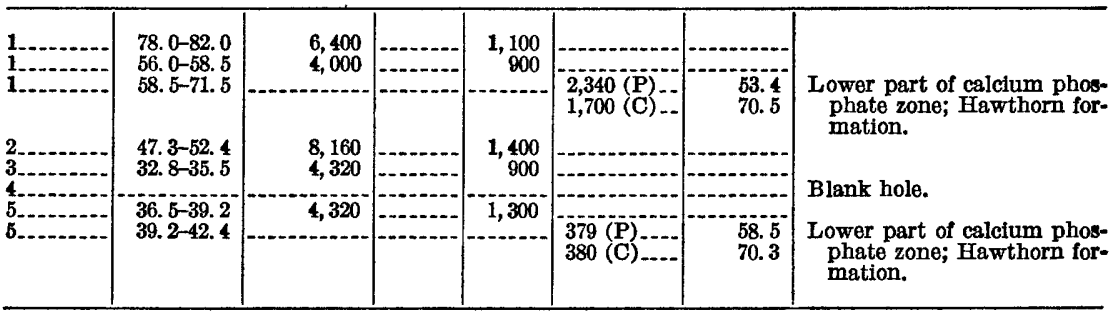

\section{Cross section 17}

[Chemical analyses by G. J. Daniels, A. Sweeney, W. P. Tucker, J. Budinsky. Radiometric (eU) analyses by J. H. Goode, Jr., B. A. McCall]

\begin{tabular}{|c|c|c|c|c|c|c|c|}
\hline & $17.3-25.0$ & 12,320 & & 1,000 & & & \\
\hline $1 \ldots+\ldots$ & 25. 0-39. 3 & 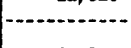 & & $-\infty+\infty$ & $\cdots$ & - & $\begin{array}{l}\text { Possible calcium phosphate } \\
\text { zone. }\end{array}$ \\
\hline 2 & $\begin{array}{l}\text { 29. } 5-39.0 \\
\text { 39. } 0-43.0 \\
\text { 43. } 0-52.0\end{array}$ & 15,200 & 0.007 & $\mid-n-n$ & 790 & 63.5 & Not sampled. \\
\hline 3ב-n- & $\begin{array}{l}\text { 20. } 0-23.0 \\
23.0-29.0\end{array}$ & $\begin{array}{r}4,800 \\
\hdashline\end{array}$ & & 3,500 & $\mid 2,960(\mathrm{C})$ & $\begin{array}{r}68.3 \\
\hdashline 6.6\end{array}$ & \\
\hline $\begin{array}{l}4 \\
5 \\
6 \\
7 \\
8\end{array}$ & $\begin{array}{r}7.4-15.8 \\
1.5-6.0 \\
9.0-12.0 \\
4.0-10.5 \\
53.5-64.5 \\
15.5-25.5 \\
72.5-78.0\end{array}$ & $\begin{array}{r}18,440 \\
7,200 \\
4,800 \\
10,400 \\
17,600 \\
16,000 \\
8,800\end{array}$ & 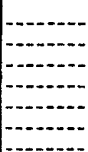 & $\begin{array}{r}1,100 \\
1,100 \\
900 \\
800 \\
1,200 \\
1,100 \\
1,100\end{array}$ & 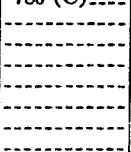 & $\mid \begin{array}{l}-20 \\
-1\end{array}$ & \\
\hline $10 \ldots$ & $78.0-87.0$ & . & - & $\ldots$ & $840(\mathrm{C})$ & $74 \pm$ & $\begin{array}{l}\text { Grades estimated. Sample } \\
\text { analyzed included only a } \\
\text { part of the calcium phos- } \\
\text { phate zone. }\end{array}$ \\
\hline $11 \ldots \ldots$ & 4. $0-11.3$ & 11,680 & & 800 & & & \\
\hline
\end{tabular}

\section{Cross section 18}

[Chemical analyses by G. J. Daniels, A. Sweeney, W. P. Tucker, J. Budinsky. Radiometric (eU) analyses by J. H. Goode, Jr., B. A. McCall]

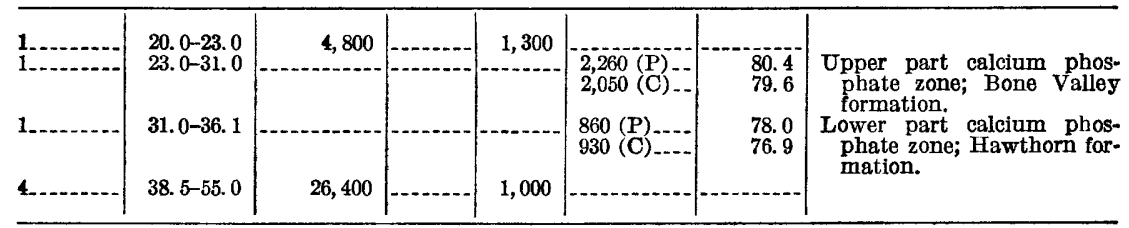





\section{INDEX}

Alachua formation, general features...... 233-234 stratigraphic correlation, cross section $17 . . \quad 264$ Aluminum phosphate minerals, where formed. Aluminum phosphate zone, characteristics.distribution. economic details, cross section 1 .

cross section 2

cross section 3 .

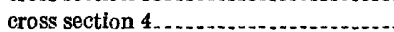

cross section 5..............................

cross section 6

cross section 7 .

cross section 8

cross section 9

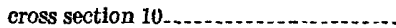

cross section 11 .

cross section 12

cross section 13 .

cross section 14

cross section 1

cross section 16.........................

cross section 17 .

cross section 18......................... 266

economic factors........................... 241-242 relation to calcium phosphate zone..... 242-243 tonnage dats, calculations................. 266 computations......................... 287-295

Analyses, chemical .................... 237, 271-295 radiometric -271-295

Barlow, I. H., analyst

271 ,

$272,273,274,275,276,278,287,288,289,290,291$

Bedclay, definition.

Bethea, S., analyst.................. 272, 273, 287, 288

Bone Valley formation, chemistry .......... 237, 238 general features .................. 234-235

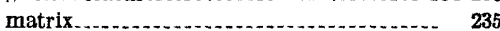
mineralogy ................... 235, 236 stratigraphlc correlation, cross section 1... 246

cross section 2 246-247

cross section $3 \ldots \ldots \ldots$

cross section $4 \ldots \ldots$

eross section 5 . . . . . . . . .

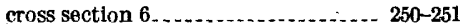

cross section $7 \ldots \ldots \ldots$

cross section 8........................ 252

cross section $9 \ldots \ldots \ldots \ldots$

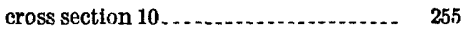

cross section 11...................... 256

cross section 12 ........................... 258

cross section 13........................ 259

cross section 14_................... 260-261

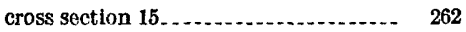

cross section 16 ................. 263
Bone Valley formation-Continued stratigraphic correlation-continued Page cross section 17........................ 264-265 cross section 18

lithologic criteria........................ 245

weathering............................. 239

Brodkorb, Pierce, quoted...................... 234

Budinsky, J., analyst....................... 271, $272,273,274,275,276,278,281,282,283,284$, $285,286,287,288,289,290,291,292,293,294,285$.

Calcium, ratio to phosphate................. 238

Calcium phosphate zone, characteristics...... 240 distribution . . . .......................... 242-243 economic details, cross section ............ 246

cross section 2...................... 247

cross section 3..................... 248

cross section 4 ...................... 249

cross section 5..................... 250

cross section 6 . . . . .

cross section $7 \ldots \ldots \ldots \ldots \ldots$

cross section $8 \ldots \ldots \ldots \ldots \ldots . . . . . . . . . . . .253$

cross section $9 \ldots \ldots \ldots$

cross section 10..................... 255

cross section $11 \ldots \ldots \ldots \ldots$ 256-257

cross section 12.................... 258

cross section 13 . .

cross section 14....................... 261

cross section 15...................... 262

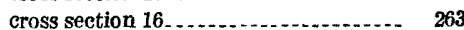

cross section $17 \ldots \ldots \ldots$

cross section $18 \ldots \ldots$

economic factors .......................... 240-241

relation to aluminum phosphate zone _-- 242-243

tonnage data, calculations.............. 266-267

computations......................... 287-295

Campbell, E., analyst.................... 271, 272 ,

$273,274,275,276,278,287,288,289,290,291$

Chemical analyses..................... 237, 271-295

Daniels, G. J., analyst .................... 276, $281,282,284,285,286,290,292,293,294,295$

Drilling procedures............................ $\quad 222$

Flanagan, F., analyst.......................... 224

Fluorine, ratio to phosphate............... 238

Fossils, Hawthorn formation............... 230-231

Ocala limestone........................... 226

Suwannee limestone........................ 227

Tampa limestone....................... 228-229

Geologic history ............................. 225

Goode, J. H., Jr., analyst.................. 271, 272, $273,274,275,276,278,281,282,283,284,285$, $286,287,288,289,290,291,292,293,294,295$ 
Hawthorn formation, chemistry dolomitization. $236,237,238$

fossils . 230-231

general features

229-231 mineralogy -........... 235, 236

stratigraphic correlation, cross section 1... 244 cross section 2.................. 246 cross section 3... ..................... 247-248

cross section 4. . . . . . . . cross section 5 . . .

cross section 6. . . . .

cross section 7........................ 251

cross section 8 . ............................ 252

cross section $9 . \ldots \ldots \ldots \ldots \ldots$

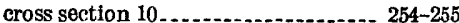

cross section $11 \ldots \ldots . . . . . . . . . . . . . . . .256$

cross section 12....................... 257

cross section 13 ....................... 259

cross section 14........................ 260

cross section 15 ....................... 262

cross section 16........................ 263

closs section 17....................... 264

cross section 18........................ 265

lithologic criteria.......................... 245

weathering

Jenkins, L., analyst.

$272,273,274,275,276,278,287,288,280,200,201$

Laboratory procedures

222,224

Limestone unit, unnamed. See Onnamed sand and limestone.

Location of area 222,223

McCall, B. A., analyst. 271 , $272,273,274,275,276,278,281,282,283,284$, $285,286,287,288,289,290,291,292,293,294,295$

MacNell, F. Stearns, fossil determinations.... 224

Matrix, definition. 240

Hawthorn formation . ................... 235, 236

relation to calcium phosphate zone...... 240

Moy, I., analyst............................. 224 Mineralogy, Bone Valley formation . ....... 235, 236

Haw thorn formation . . .................. 235, 236

Moore, R., analyst_.274, 275, 276, 278, 281, 282, 283, $284,288,289,290,291,293,294$

Murphy, T., analyst_........................ 278, $281,282,283,284,291,292,293,294$

Nodules, phosphate content.................... $\quad 238$ uranium content

Ocala limestone, fossils. ...................... $\quad 226$ general features............................ 226, 227 stratigraphic correlation, cross section 15 _.. 261-262 cross section 16 . Iithologic criteria...................... 245

Radiometric analyses $271-295$

Samples, preparation 223-224

Sand unit, unnamed. See Unnamed sand and limestone.

Screen data
Smith, J., analyst. . . . . $272,273,274,275,276,278,287,288,289,290,291$ Smith, R., analyst........................... 271, $272,273,274,275,276,278,287,288,289,290,291$ Stratigraphic coirelation, lithologic criteria... 245 Stratigraphic correlation. See formation names.

Surficial deposits.

Suwannee limestone, fossils. .................. 227

general features............................ 226-227

stratigraphic correlation, cross section 1... 244 cross section 2_...................... 246 cross section 17........................ 264 lithologic criteria................... 245

Sweeney, A., analyst................... 278. 281, $282,283,284,285,286,291,292,293,294,295$

Tampa limestone, fossils . . . . . . . . . . . . 223-229 general features.......................... 228-229 stratigraphic correlation, cross section 1.- 244 cross section 2......................... 246 cross section $3 \ldots \ldots \ldots$

cross section 4............................. 248

cross section 14......................- 260

cross section $17 \ldots \ldots$

lithologic criteria...................-. 245

Teriace sand, general features...... 235 stratigraphic correlation, cross section $1 \ldots \quad 246$ cross section $2 \ldots \ldots$ cross section 3 . cross section 4........................ 249 cross section 5 ... cross section 6........................... 251 cross section 7........................ 251-252 cross section 8....................... 252

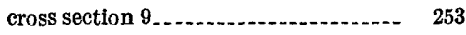
cross section $10 \ldots \ldots \ldots$ cross section $11 \ldots \ldots \ldots$ cross section $12 \ldots \ldots \ldots$ cross section 13..................... 259 cross section 14........................ 261 cross section 15 ..................... 262 cross sectiou 16......................... 263 cross section 17_....................... 265 cross section 18_................... 265-266 litbologic eriteria...................... 245

Tucker, W. P., analyst_........... 271. $272,273,274,275,276,278,285,286,287,288$, 289, 290, 281, 294, 295.

Unnamed sand and limestone, chemistry ... 236, 237 fossils . . . . . . . general features ......................... 231-232 stratigraphic correlation, cross section 10_- 255 cross section 11....................... 256 cross section 12_................... 257-258 cross section 13....................... 259 cross section $14 \ldots \ldots$

cross section 15...................... 262 Uranium content, phosphate nodules........ 238, 241

Waring, J., analyst........................... 278, $281,282,283,284,291,292,293,294$ Weathering, land-pebble district. . . . . ...... 238-239 




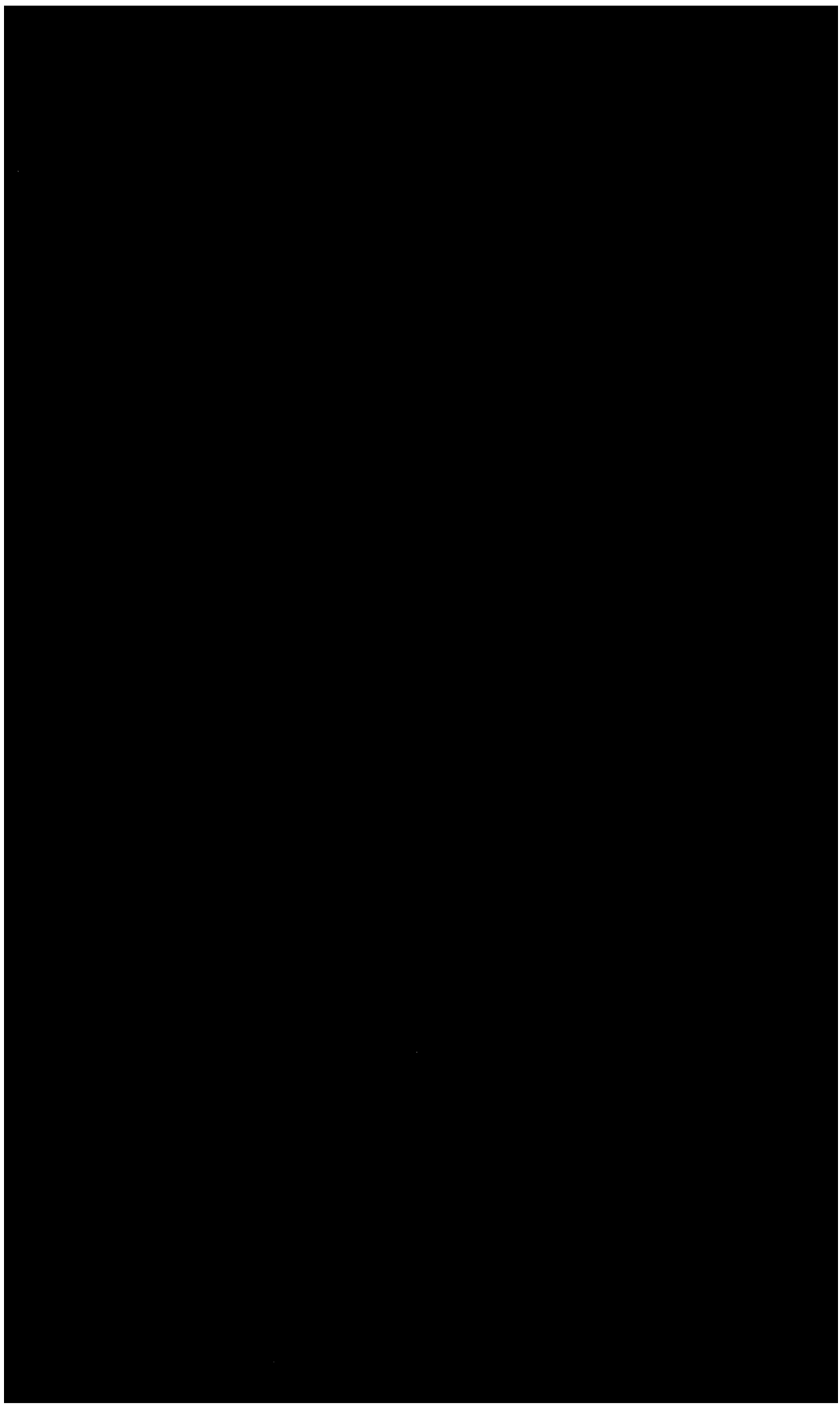




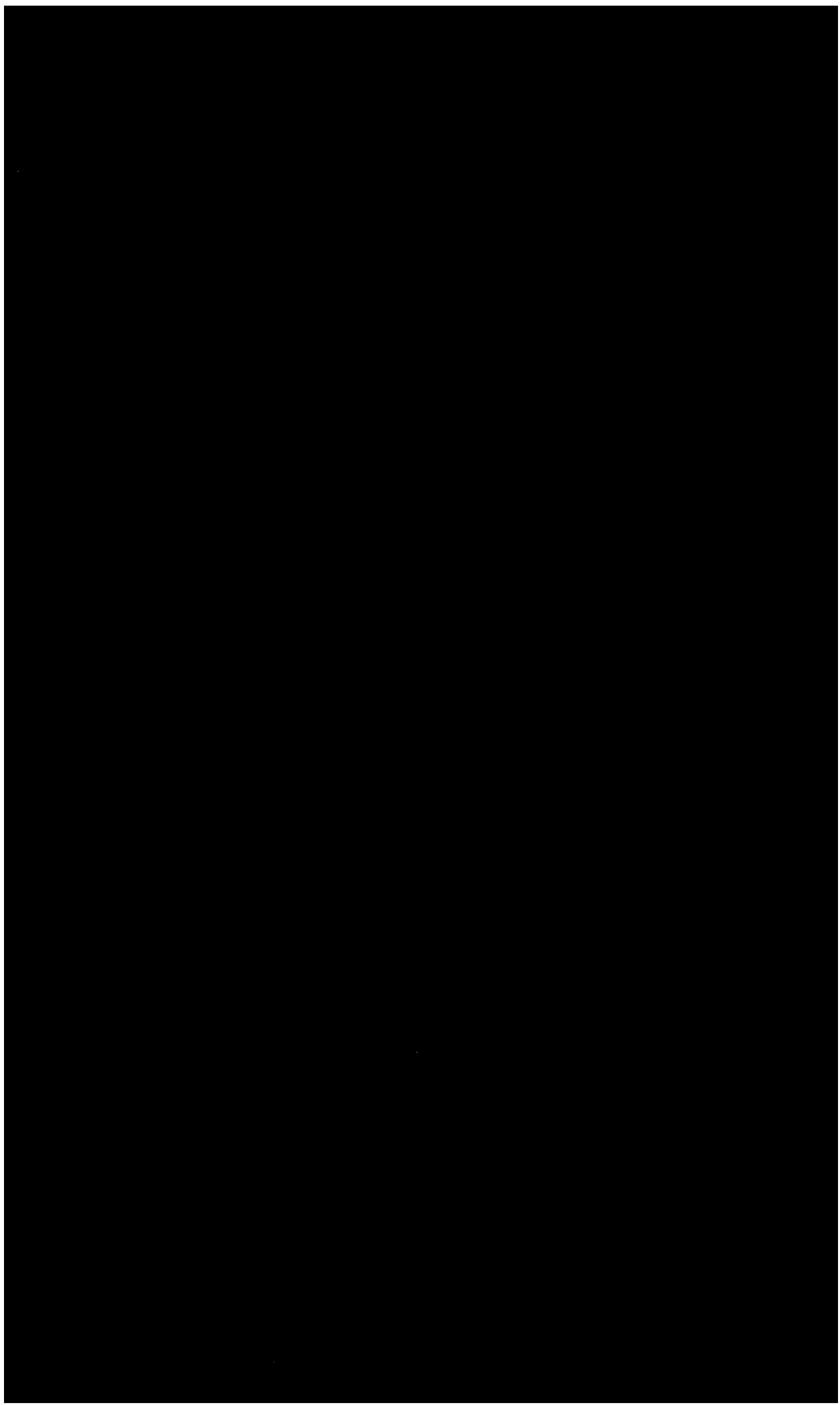

